$$
\begin{gathered}
\text { Universidade de São Paulo } \\
\text { Instituto de Geociências } \\
\text { Programa de Pós-Graduação em Geoquímica e Geotectônica }
\end{gathered}
$$

\title{
Proveniência e retrabalhamento sedimentar das areias da Volta Grande do rio Xingu, PA
}

Dissertação de Mestrado

Aluno: Rodolfo Carlos Mineli

Orientador: André Oliveira Sawakuchi

São Paulo 
Ficha catalográfica preparada pelo Serviço de Biblioteca e Documentação do Instituto de Geociências da Universidade de São Paulo

Mineli, Rodolfo Carlos

Proveniência e retrabalhamento das areias da Volta Grande do Rio Xingu, PA / Rodolfo Carlos Mineli. - São Paulo, 2013

$64 \mathrm{p}$.

Dissertação (Mestrado) : IGC/USP

Orient.: Sawakuchi, André Oliveira

1. Proveniência 2. Retrabalhamento 3.Areia 4. Luminescência 5. Rio Xingu I. Título 
"A pesquisa não tem fim."

(Ana Góes) 


\section{Agradecimentos}

Durante minha pós-graduação aceitei uma oportunidade que consumiu muito do meu tempo. E para concluir esta dissertação de mestrado dependi do auxílio de muitas pessoas, mesmo que indiretamente. Todas elas merecem um agradecimento a altura, que não caberia neste papel.

Primeiramente, agradeço ao meu orientador, professor e amigo Prof. Dr. André Oliveira Sawakuchi pela sempre generosa paciência, apoio e sabedoria, que mesmo nos momentos mais inconclusivos é capaz de encontrar as soluções mais práticas. Também é grande responsável pela elaboração desta dissertação, com argumentos pertinentes e ajuda imensurável. Obrigado.

À minha família pelo apoio e compreensão pelo tempo que tive de me dedicar para conclusão desta dissertação. Em especial á minha avó, Elis Francischini, que sempre me inspira.

Ao amigo Prof. Dr. Daniel Rodrigues do Nascimento, o Pegmatito, pela ajuda na descrição e contabilização dos minerais pesados. À Me. Johanna Mendes, pela ajuda na preparação das amostras. Ao Prof. Dr. Carlos Henrique Grohmann de Carvalho (Guano) pela confecção dos perfis batimétricos, ajuda e ótimas conversas em campo.

Ao Prof. Dr. Carlos Conforti Ferreira Guedes pela ajuda em campo, principalmente no trabalho braçal em cavar a litologia FDP. Também pelas aulas de bullying e boas risadas mesmo nos momentos mais drásticos do campo. E principalmente, por ter salvo nosso grupo ao reconhecer um jacaré.

À Me. Manuela Pinheiro Ferreira, a Pinhão, pela grande ajuda em campo e ótimas risadas, mesmo que ela não estivesse rindo.

Aos amigos biólogos que nos acompanharam nesse campo dividindo conhecimento boa companhia e ótimas risadas, Me. Ilana Fichberg, Me. Marcelo Melo, os professores da UFPA e especialmente ao Me. Henrique Oliveira Sawakuchi, por ter apagado o incêndio do nosso acampamento no posto do IBAMA.

Ao Milton Fortunato Amendola Junior pela organização do material de campo e ajuda.

Aos barqueiros, pela ajuda imensurável que nos conduziu por caminhos certos com muita astúcia e conhecimento a cerca do rio Xingu. 
Um grande agradecimento para os amigos que fiz na graduação e sempre me apoiaram e me incentivaram para concluir a dissertação. Embora me chamassem todos os fins de semana pra sair, ou quase todos os dias para beber (Massa) e me xingavam porque não podia! São eles: Aline Mota de Souza, Mariana Tísel Yamamoto, Stephano Pessini da Silva, Sheila Schuindt do Carmo e outros que já me desculpo por esquecer.

Aos amigos que não tive tanto tempo em ver durante este último ano, mas com toda certeza não esqueci e me orgulho muito de nossa amizade, Gabriel Fernandes Fonzaghi, Ana Sakamoto, Thiago Colombo de Lima.

Aos recentes amigos adquiridos na Petrobras que deram todo apoio e força que foram exigidos nos dias mais quentes do Rio, e me fizeram focar na dissertação e não na praia, Luma Botelho de Souza, Nick Dourado Belem de Oliveira, Alexandre Scussel Zanatta, Julia Campos Guerrero, Valter Oliveira Rebouças, Gabriel Medeiros Marins, Papai Rafael Valadão, Mamãe Thais Fernandes, Krishna Milani Simões, Talles Meneguim, Rodrigo Borges entre outros que com certeza esqueci.

Agradeço especialmente ao sensei Haroldo Key Inazawa e sua turma matutina Karate do CEPEUSP, em especial Jorjão e Sanduba, que foram, sem dúvida grandes responsáveis pela minha assiduidade na pós-graduação, além de melhorar minha concentração e determinação. Obrigado sensei pelos ensinamentos que guardarei para o resto da vida.

Agradeço à FAPESP pela respeitada oportunidade de bolsa de mestrado.

Por fim, agradeço a Deus. 


\section{Resumo}

O rio Xingu na região de Altamira (PA) destaca-se pela diversidade de sua dinâmica sedimentar e geomorfologia fluvial. Essa região é conhecida como a Volta Grande do rio Xingu devido ao seu curso fluvial atípico. Destacase ainda que esta diversidade fluvial passará por grandes modificações com a implantação do empreendimento hidroelétrico de Belo Monte.

Análises granulométrica, de minerais pesados e de luminescência do quartzo e feldspato, combinadas com geomorfologia por sensoriamento remoto, foram utilizadas para avaliação da proveniência e dinâmica de transporte dos sedimentos da Volta Grande do rio Xingu. Em relação à morfologia fluvial e características dos sedimentos arenosos, a Volta Grande do rio Xingu pode ser dividida nos seguintes setores: 1 . setor com fisiografia de canal afogado faminto, dominado por sedimentos lamosos e com acúmulo de sedimentos arenosos (areia média) somente nas porções marginais do canal, assembléia de minerais pesados caracterizada por andaluzita, estaurolita, turmalina e zircão; 2. setor de canal único encaixado, com complexo de barras em forma de delta, areias finas a muito finas, com assembléia de minerais pesados caracterizada por hornblenda, piroxênio, epidoto, turmalina e zircão, baixo teor de feldspato (média: IR=500) e sensibilidade da luminescência do quartzo moderada (médias: $T L=175000$ e A-LOE=20000); 3. setor com canais múltiplos e alta densidade de barras arenosas, com areias de granulação bimodal (muito fina a fina e grossa a muito grossa), assembléia de minerais pesados constituída por hornblenda, estaurolita, epidoto, turmalina e limonita, baixa quantidade de feldspato (média: $I R=500$ ) e quartzo com sensibilidade de luminescência moderada (médias: $T L=180000$ e A-LOE= 19000); 4. setor caracterizado pela confluência dos rios Xingu e Iriri, com predomínio de areias grossas, assembléia de minerais pesados constituída por hornblenda, granada, zircão e limonita, elevada quantidade de feldspatos (média: IR=1800) e quartzo com sensibilidade da luminescência relativamente baixa (média: $T L=50000$ e A-LOE=9000); 5. setor do rio Xingu a montante do rio Iriri, com predomínio de barras formadas por areia média a fina, assembléia de minerais pesados caracterizada por hornblenda, estaurolita, epidoto, turmalina, zircão e limonita, baixo teor de feldspato (média: IR=500) e quarzto com sensibilidade da 
luminescência elevada (média: TL=270000 e A-LOE=30000). A sensiblidade da luminescência do quartzo indica variação do grau de retrabalhamento das areias da Volta Grande do rio Xingu. Estas características indicam dinâmica fluvial distinta nos diferentes domínios morfológicos descritos, que propicia deposição de fácies distintas e variação do tempo de estocagem e retrabalhamento de sedimentos. Isto indica que a fisiografia do rio Xingu relaciona-se ao transporte e deposição de modas granulométricas distintas. As areias grossas com menor grau de retrabalhamento são supridas pelo rio Iriri. Areias provenientes do rio Iriri tem dificuldade de se misturar com areias derivadas de setores à montante do rio Xingu. Isto pode causar interpretação equivocada das fontes e modo de transferência dos sedimentos da Volta Grande do rio Xingu.

\section{Abstract}

The Xingu river in the region of Altamira (PA) stands out due to its diversity of sedimentary dynamics and atypical geomorphological features. This region is known as the Volta Grande do rio Xingu,. We also highlitghted that this fluvial diversity may suffer changes due to the building of dams for the Belo Monte hydroelectric achievement.

Grain size, heavy minerals and quartz and feldspar luminescence analysis, combined with remote sensing geomorphological analysis, were used to interpret the mode of sediment transport and deposition throughout the Volta Grande do rio Xingu. The studied stretch of the Xingu river can be divided in the following sectors: 1 . sector with drowned channel physiography, dominated by muddy sediments and with medium sand concentrated in the channel margins, heavy mineral assemblage characterized by andalusite, staurolite, tourmaline and zircon; 2. inlet single-channel with delta-shaped bars dominated by fine and very fine sands, heavy mineral assemblage characterized by hornblende, pyroxene, epidote, tourmaline and zircon, low feldspar content (mean: IR=500) and sands with quartz of moderate sensitivity (mean: $T L=175000$ and A$L O E=20000$ ); 3. multi-channel sector with dense bars deposits and sands with bimodal grain size (fine to very fine and coarse to very coarse sands), with heavy mineral assemblage characterized by hornblende, staurolite, epidote, 
tourmaline and limonite, low feldspar content (mean: $I R=500$ ) and quartz with moderate luminescence sensitivity $(T L=180000$ and $A-L O E=19000) ; 4$. the Iriri river's sector, with thicker sandy facies, heavy mineral assemblage characterized by hornblende, garnet, zircon and limonite, high feldspar content (mean: $I R=1800$ ) and quartz with low luminescence sensitivity (mean: $\mathrm{TL}=50000$ and $\mathrm{A}-\mathrm{LOE}=9000$ ); 5. Xingu river upstream the Iriri river mouth comprises medium to fine sand facies, heavy mineral assemblage characterized by hornblende, staurolite, epidote, tourmaline, zircon and limonite, low feldspar content (mean: $I R=500$ ) and quartz with high luminescence sensitivity (mean: $T L=270000$ and $A-L O E=30000$ ). The fluvial morphology and characteristics of sands from these sectors indicate variation in fluvial dynamics and sediment provenance throughout the Volta Grande of the Xingu river. This gives origin to distinct facies deposition and degree of sediment recycling and storage. Thus, there is great relation between fluvial dynamics and Xingu river physiography, which dificult the mixing of coarse and finse sands determining the grain size and provenance of sands distributed throughout the lower Xingu river. This complex sedimentary dynamics should be considered in environmental impact studies dealing with changes in sedimentation. 


\section{Índice}

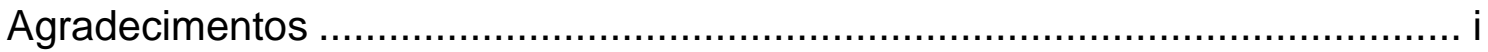

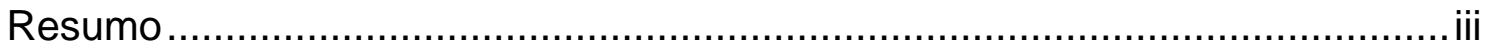

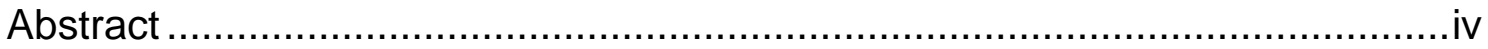

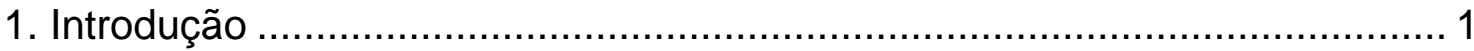

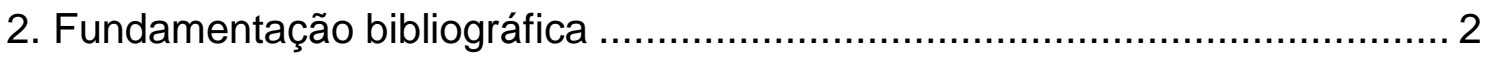

2.1 Localização, contexto geológico regional e aspectos fisiográficos ........... 2

2.2 Pluviosidade e neotectônica na região do baixo rio Xingu (PA)............... 7

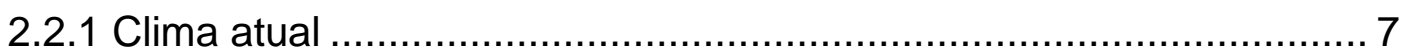

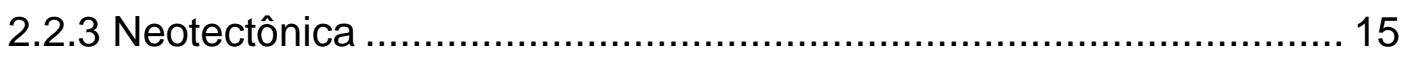

2.3 Termoluminescência (TL), luminescência opticamente estimulada (LOE)

2.4 Controles geológicos sobre a luminescência do quartzo ....................... 22

2.5 Uso da LOE do quartzo para determinação do grau de retrabalhamento

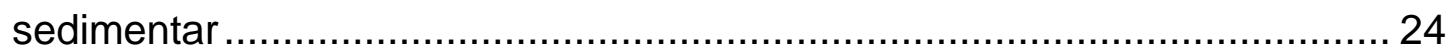

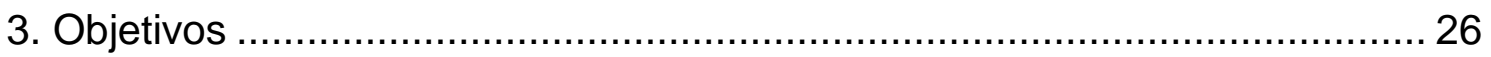

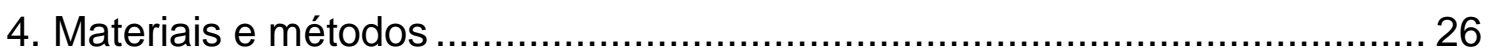

4.1 Análise geomorfológica................................................................. 26

4.2 Análise sedimentológica de campo e coleta de amostras .................... 27

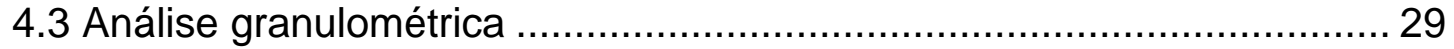

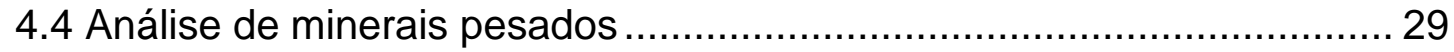

4.5 Medidas de sensibilidade da luminescência ................................... 29

4.6 Análise estatística dos dados ....................................................... 31

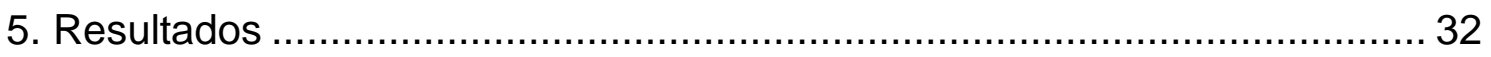

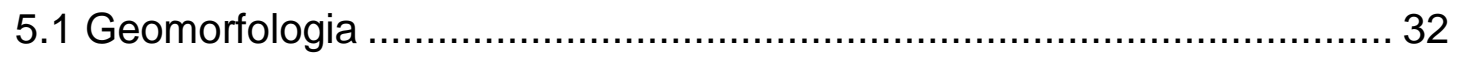

5.2 Análise de fácies................................................................. 35

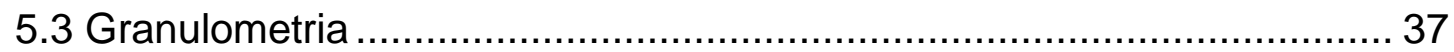




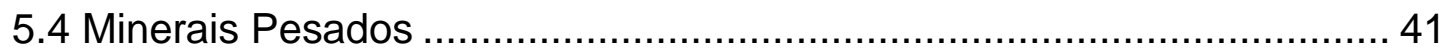

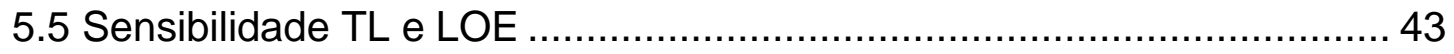

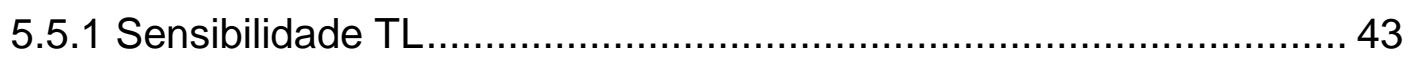

5.5.2 Sensibilidade LOE .............................................................. 45

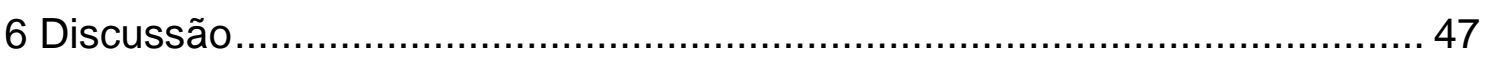

6.1 Proveniência, transporte e estocagem de sedimentos ........................... 47

6.2 Possíveis impactos na dinâmica sedimentar associados ao empreendimento hidroelétrico de Belo Monte ............................................. 55

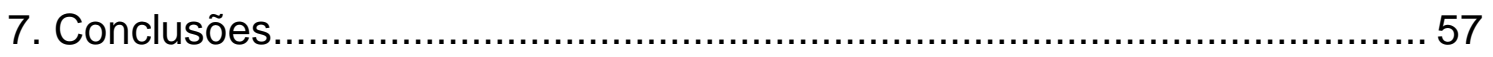

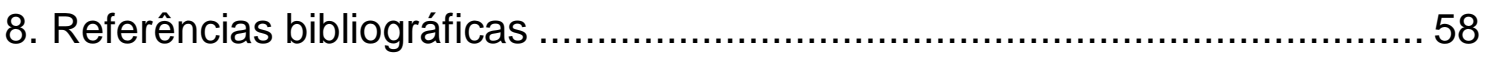




\section{Introdução}

Esta dissertação de mestrado visa caracterizar a proveniência e o grau de retrabalhamento sedimentar das areias da Volta Grande do rio Xingu na região de Altamira (PA). Este setor do rio Xingu é destacado pela diversidade de sua dinâmica sedimentar e morfologia ímpar. Neste intervalo de cerca de $400 \mathrm{~km}$, desde o rio Iriri, seu principal tributário situado cerca de $80 \mathrm{~km}$ a sul de Altamira, até a foz com o Amazonas, nota-se grande variação de sua dinâmica deposicional, representada por zona dominada por barras arenosas longitudinais, zona erosiva com corredeiras e canais múltiplos retilíneos e zona de canal largo único com influência da maré e fisiografia de afogamento. Esta diversidade fisiográfica define a singularidade do rio Xingu. Destaca-se ainda que esta diversidade fisiográfica pode sofrer grandes modificações no futuro próximo devido à implantação das barragens do empreendimento hidroelétrico de Belo Monte.

Este estudo visa à caracterização da geomorfologia e dinâmica sedimentar da Volta Grande do rio Xingu, com foco nos sedimentos arenosos. Estudos sobre a dinâmica de transporte da carga de fundo dos rios amazônicos são raros. Para isto, foram usados métodos de sensoriamento remoto para análise geomorfológica e análises granulométricas e de sensibilidade da luminescência opticamente estimulada (LOE) para inferência da proveniência e grau de retrabalhamento das areias da Volta Grande do rio Xingu. O uso da sensibilidade LOE do quartzo como indicador de grau de retrabalhamento sedimentar pode ser de grande utilidade ao estudo de sistemas fluviais. Estudos recentes (Pietsch et al., 2008; Sawakuchi et al., 2011a) têm demonstrado que a sensibilidade LOE do quartzo correlaciona-se à sua história deposicional (ciclos de erosão e deposição). Ambos os estudos sugerem que a sensibilidade LOE pode ser usada como indicador do grau de retrabalhamento de sedimentos, podendo fornecer também informações acerca da dinâmica fluvial. 


\section{Fundamentação bibliográfica}

\subsection{Localização, contexto geológico regional e aspectos fisiográficos}

O rio Xingu pertence à bacia hidrográfica amazônica, sendo um dos maiores afluentes do rio Amazonas. Corre na direção sul-norte, paralelo aos rios Tapajós e Tocantins, entre os paralelos $1^{\circ}$ e $15^{\circ}$ de latitude sul e os meridianos $50^{\circ}$ e $56^{\circ}$ de longitude oeste, com nascentes no Planalto dos Guimarães, centro leste de Mato Grosso, e foz no trecho final do rio Amazonas, nordeste do Pará. A bacia do rio Xingu abrange uma área de drenagem de aproximadamente $520.000 \mathrm{Km}^{2}$ e cerca de $2.000 \mathrm{Km}$ de comprimento com vazão média entre 2.582 e 9.700 m³/s (Pettena et al., 1980; Latrubesse et al., 2005). A cobertura vegetal original é do tipo floresta tropical densa e o clima é tropical úmido. A pluviosidade nessa região é alta, variando de 1750 a 3500 mm por ano (Amaral, 1980).

A área de estudo está localizada no trecho do rio chamado Volta Grande (município de Altamira, Pará), no limite sudeste da Bacia Sedimentar do Amazonas (Figura 1). Esta região é conhecida pelo percurso atípico e morfologia diversificada do rio Xingu. A maior parte da sua bacia de drenagem encontra-se sobre o cráton do Amazonas, o qual possui aproximadamente 4.300.000 Km², sendo limitado pelos cinturões orogênicos proterozóicos Tucavaca a oeste, Araguaia-Cuiabá a sul e Tocantins a oeste (Tassinari \& Macambira, 2004). A Volta Grande do rio Xingu está inserida na porção setentrional da Província Amazônica Central (Tassinari \& Macambira, 1999; Tassinari \& Macambira, 2004), no limite entre a bacia sedimentar do Amazonas (Paleozóico ao Neógeno) e seu embasamento formado por unidades mesoarqueanas a paleoproterozóicas (Rocha Neto et al., 2004). Estas unidades são representadas por charnockitóides e por gnaisses tonalíticos, granodioritos e granitóides do Complexo Xingu (Rocha Neto et al., 2004). Também ocorrem unidades metavulcanossedimentares do Neoarqueano formadas por actinolita xistos, mica xistos, anfibolitos, rochas metavulcânicas, metatufos, filitos, quartzitos e formações ferríferas bandadas. De acordo com Rocha Neto et al. (2004), estas unidades são cortadas por suítes intrusivas do Riaciano (Suíte Intrusiva Igarapé Urucu) e do Orosiriano (Suíte Intrusiva 
Parauari) compostas por rochas graníticas diversas (monzogranito, granito, granodiorito, sienogranito e tonalito). Ao adentrar no domínio da bacia sedimentar do Amazonas, o rio Xingu corre paralelo ao arco de Gurupá até a sua foz. A origem da bacia sedimentar do Amazonas estaria vinculada à Orogenia Brasiliana/Pan-Africana, que gerou esforços compressivos lesteoeste e de alívio norte-sul (Cunha et al., 2007). Na região da Volta Grande do rio Xingu, a bacia sedimentar do Amazonas é representada pelo Grupo Trombetas (Siluriano-Devoniano) e pelas formações Maecuru, Ererê (Devoniano) e Alter do Chão (Cretáceo), além de rochas ígneas básicas do magmatismo triássico Penatecaua (Cunha et al., 2007). O grupo Trombetas abrange sedimentos marinhos e costeiros, sendo representado pelas formações Autás Mirim (arenitos e folhelhos de plataforma rasa), Nhamundá (arenitos de plataforma rasa com influência glacial), Pitinga (folhelhos e diamictitos de plataforma distal), Manacapuru (arenitos e pelitos deltaicos) e Jatapu (arenitos e siltitos de plataforma rasa). As formações Maecuru e Ererê são representadas por arenitos, siltitos e folhelhos de plataforma marinha rasa (Caputo, 1984). Durante o Neotriássico ocorreram esforços distensivos, na direção leste-oeste, relacionados à abertura do oceano Atlântico. Esses esforços foram seguidos de magmatísmo básico, registrado por diques e soleiras de diabásio, que constituem o Magmatismo Penatecaua (Thomaz Filho et al., 1974). A Formação Alter do Chão, que recobre em discordância erosiva as unidades subjacentes, é constituída principalmente por arenitos grossos e conglomerados de sistemas fluvial e lacustre.

Na região de Altamira (PA), o rio Xingu destaca-se pela diversidade de sua dinâmica sedimentar. A região da Volta Grande do rio Xingu apresenta cerca de $200 \mathrm{~km}$, onde nota-se grande variação de sua fisiografia (Figura 2). A região é conhecida por apresentar desnível de $85 \mathrm{~m}$, atípico para rios da bacia amazônica, que resultaria de esforços trativos do Neógeno (Pettena et al., 1980), os quais teriam desenvolvido os trechos encachoeirados da Volta Grande do Xingu (Rodriguez, 1993).

Embora apresente grande descarga d'água, o rio Xingu carrega quantidades relativamente pequenas de sedimentos em suspensão, cerca de 17,8 ton $/ \mathrm{Km}^{2}$ ano, em comparação a aproximadamente 170 ton $/ \mathrm{km}^{2}$ do rio Amazonas. Isto se deve ao fato de rios que drenam áreas cratônicas 
apresentarem menor proporção de sedimentos em suspensão em relação à carga de fundo (Latrubesse et al., 2005). Os sedimentos do rio Xingu são representados principalmente por areias depositadas em canais e barras longitudinais. Sedimentos mais antigos são representados por terraços arenosos em níveis superiores ao nível atual do rio. Além dos depósitos fluviais, a região também apresenta espessas coberturas coluviais, que podem estar associadas à evolução dos depósitos residuais de intemperismo (Pettena et al., 1980).

Vital e Stattegger (2000) propõem três estágios de evolução do Estuário do Amazonas e Xingu: (i) vales incisos relacionados à queda do nível do mar durante final do último Período Glacial; (ii) formação de grandes lagos de água doce e extensas áreas de terraços devido ao aumento do nível do mar entre o Pleistoceno tardio e Holoceno médio; (iii) atual sistema de erosão e deposição controlados por complexa interação de processos fluviais e estuarinos. Vonhof e Kaandorp (2010) também acrescentam a importância do clima quente e úmido da Amazônia e ciclos climáticos desde o Neógeno para a evolução quaternária da região. 


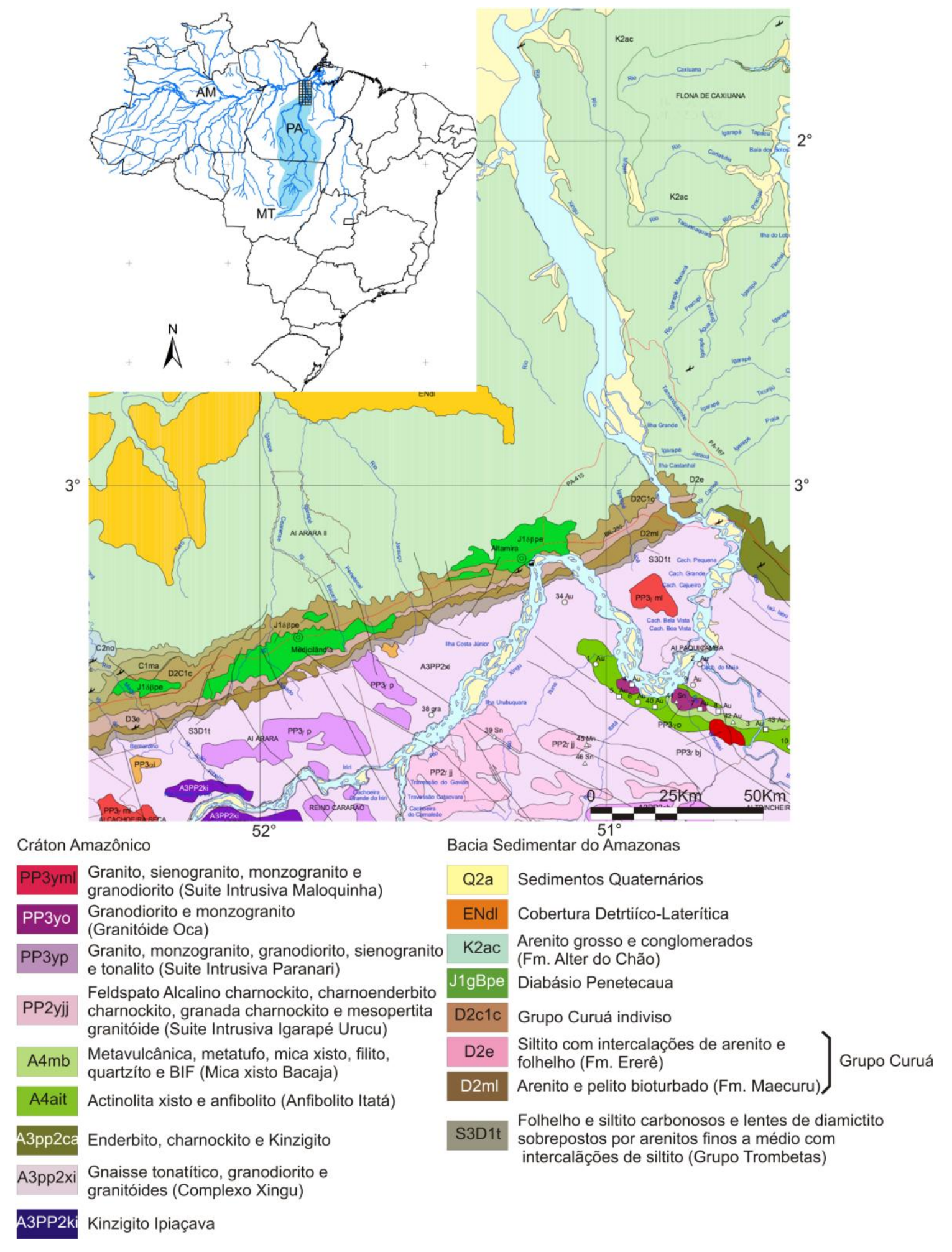

Figura 1. Localização da área de estudo e contexto geológico da Volta Grande do rio Xingu. Adaptado de Rocha Neto et al., (2004). Bacia de drenagem do rio Xingu destacada em azul no mapa. 

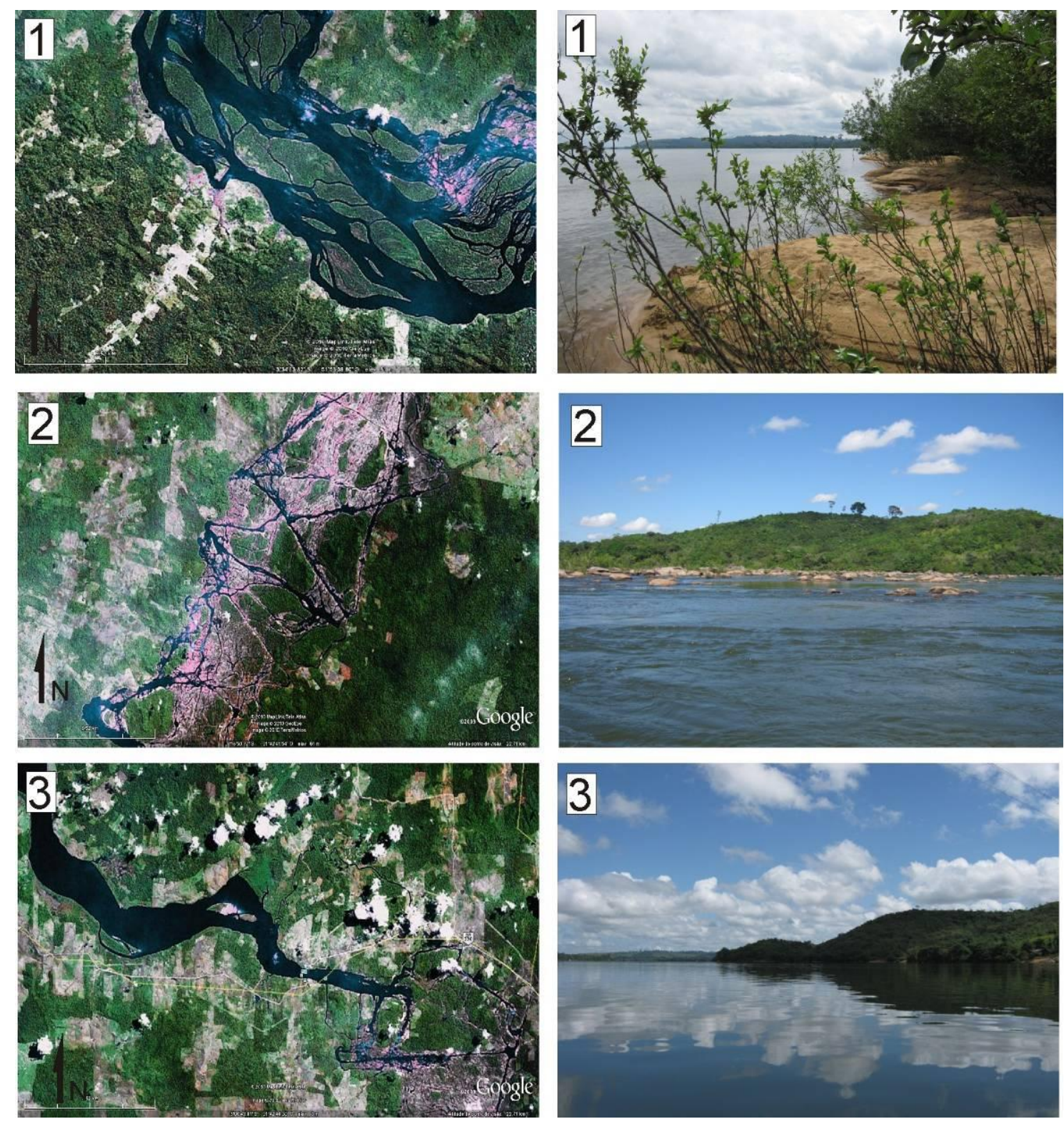

Figura 2 - Variação da fisiografia da Volta Grande do rio Xingu. 1. Setor com regime deposicional (alta deposição/espaço de acomodação), barras arenosas longitudinais e canais múltiplos sinuosos. 2. Setor com regime erosivo formado por canais múltiplos retilíneos com cachoeiras. 3. Setor com regime deposicional "faminto" (baixa deposição/espaço de acomodação), com fisiografia de vale afogado e influência da maré. 


\subsection{Pluviosidade e neotectônica na região do baixo rio Xingu (PA)}

\subsubsection{Clima atual}

\subsubsection{Pluviosidade}

A região Norte e porção setentrional das regiões Centro-Oeste e Sudeste do Brasil apresentam homogeneidade espacial e sazonal da temperatura, com médias de $26^{\circ} \mathrm{C}$ no verão e $28^{\circ} \mathrm{C}$ no inverno (INMET). Seu clima atual quente e úmido apresenta sazonalidade da pluviosidade bem definida, com registros de máxima precipitação no verão, passando dos 420 $\mathrm{mm}$ mensais, e mínima no inverno, abaixo de $10 \mathrm{~mm}$ mensais (INMET). Neste contexto, a bacia de drenagem do rio Xingu esta sujeita à sazonalidade bem definida (Figura 3).
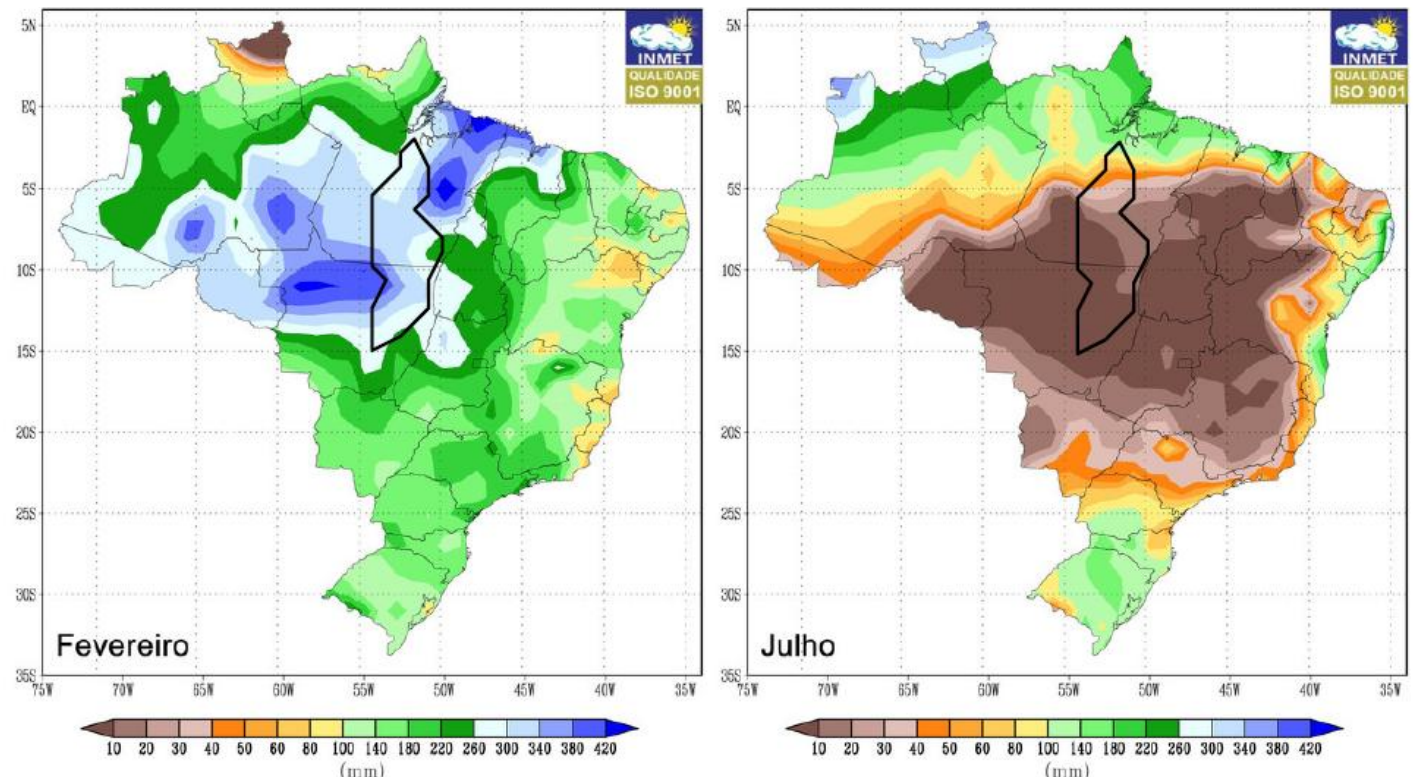

Figura 3. Normais climatológicas do Brasil no período de 1961 a 1990. Precipitações em milímetros mensais nos meses de fevereiro e julho, correspondentes aos registros médios de precipitação máxima e mínima respectivamente (INMET). Os polígonos indicam a área de drenagem do rio Xingu. 


\subsubsection{Hidrologia}

A bacia hidrográfica do rio Xingu tem área de $520.000 \mathrm{Km}^{2}$, desenvolvida no sentido sul-norte limitada pelas bacias hidrográficas do Tapajós à oeste e do Tocantins à leste. Suas nascentes se localizam no Planalto dos Guimarães, centro leste de Mato Grosso, próximo ao paralelo $15^{\circ} \mathrm{S}$, e deságua no trecho final do rio Amazonas, no nordeste do Pará, paralelo $1^{\circ} 30^{\prime \prime S}$.

A vazão no rio Xingu apresenta sazonalidade anual associada ao regime de chuvas na região, com picos de vazão máxima entre Março e Abril e mínima entre Setembro e Outubro (Figura 4). A Vazão média anual desde o ano de 1976 para estação fluviométrica em Altamira é de $8.000 \mathrm{~m}^{3} / \mathrm{s}$. No mês de Março, quando a vazão é máxima, a média é de $19.289 \mathrm{~m}^{3} / \mathrm{s}$. Em Setembro, quando a vazão é mínima, atinge $1.174 \mathrm{~m}^{3} / \mathrm{s}$. A razão entre essas vazões extremas é de 16,4, muito alta em comparação a outros tributários da margem direita do rio Amazonas (Tapajós: 4,7; Purus 6,0 e Juruá 7,6) (Molinier et al., 1995). Isto pode indicar que a vazão é mais influenciada pela morfologia dos canais, já que os rios Tapajós e Xingu correm paralelos na direção sul-norte e dividem mesmo contexto geológico e climático. Em imagens de satélite, é possível distinguir maior área de planície de inundação e canais mais sinuosos, enquanto que no trecho afogado, apesar do gradiente hidráulico inferior a outros trechos (Rodriguez 1993), essa região apresenta poucas planícies de inundação, devido à sua morfologia de afogamento.

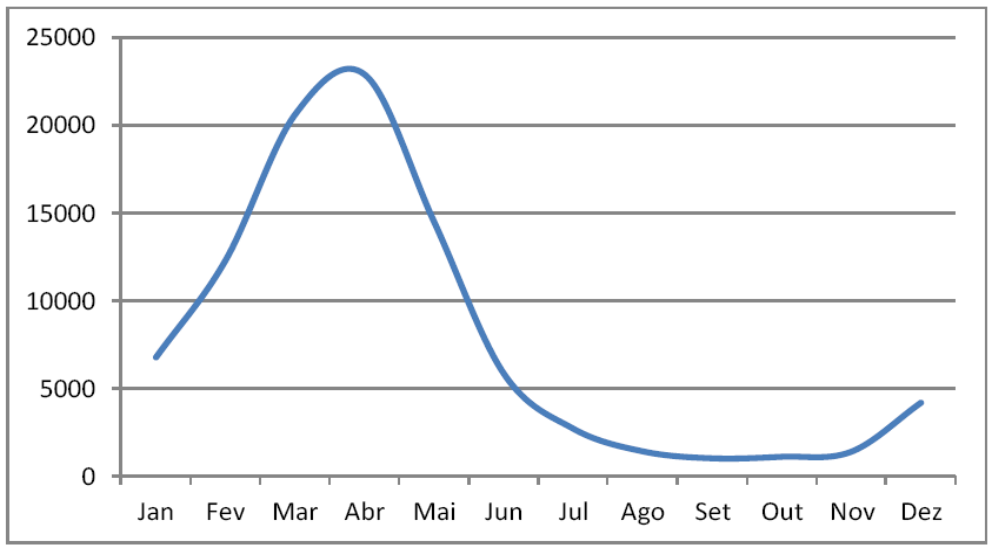

Figura 4. Variação da vazão $\left(\mathrm{m}^{3} / \mathrm{s}\right)$ do rio Xingu medida em estação fluviométrica de Altamira durante o ano de 2005. Fonte: Hidroweb. 
A vazão de um rio está sob influência da pluviosidade na sua bacia hidrográfica. Registros da vazão no rio Xingu datam desde a década de 70 . Desde aquela época, a média da vazão para o mês de Março é de $19.289 \mathrm{~m}^{3} / \mathrm{s}$. Para o mesmo período, nos anos de 1997 e 1998, a vazão foi de 9.899 e $13.412 \mathrm{~m} 3 / \mathrm{s}$, respectivamente (Figura 5). Diferenças na vazão indicam mudanças climáticas regionais que interferem no regime de chuvas. $O$ fenômeno El Niño, na maior parte da América do Sul, é associado às precipitações abaixo da média, enquanto que o La Niña, acima da média (Cruz Junior, 2009). A baixa vazão naqueles anos é interpretada como influencia do fenômeno El Niño, que desde o início dos registros, apontam para os anos de 1982-1983 e 1997-1998 como os períodos quando o fenômeno foi mais intenso.

Ciclos climáticos globais e regionais, como o ENSO e variações do ITCZ, interferem no regime de chuvas na Amazônia (Bookhagen \& Strecker, 2010; Marengo, 2005; Vonhof \& Kaandorp, 2010). No entando, a distribuição e intensidade das chuvas são complexas e distintas em regiões diferentes (Vonhof \& Kaandorp, 2010). Grande extensão da Amazônia ocidental foi atingida pela maior seca dos últimos 100 anos em 2005, e está relacionada ao fenômeno La Niña (Marengo, 2005). Nesse ano, dados fluviométricos do rio Xingu, para o mês de Março, registram aumento da vazão $\left(22.833 \mathrm{~m}^{3} / \mathrm{s}\right) \mathrm{em}$ relação à média. Isto reflete a complexidade da atuação dos fenômenos climáticos frente ao clima regional.

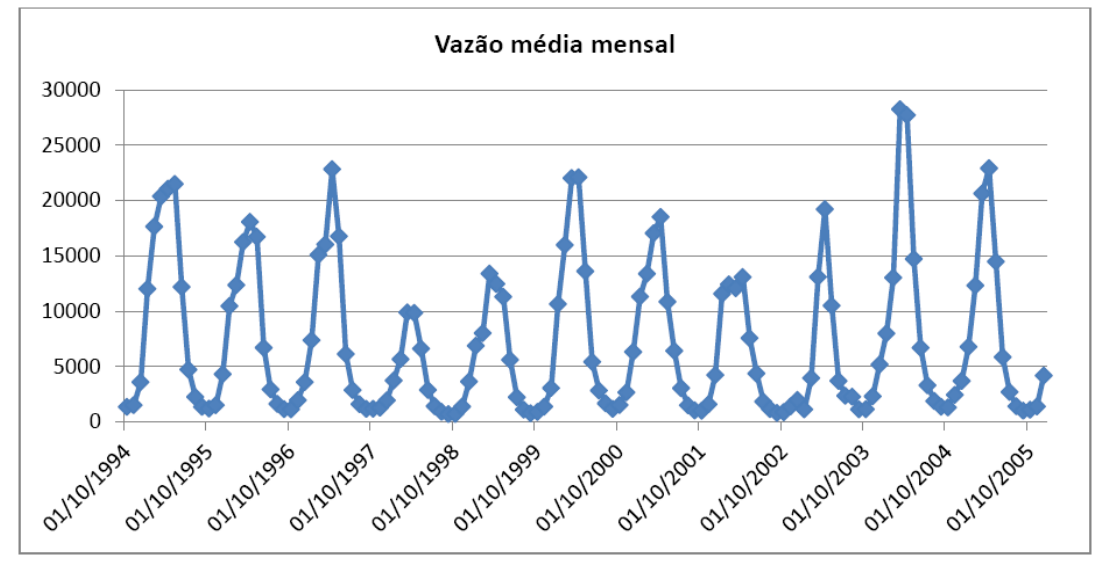

Figura 5. Dados de média mensal da vazão $(\mathrm{m} 3 / \mathrm{s})$ no rio Xingu, em estação próxima a Altamira (Baixo rio Xingu). Dados compilados da ANA (Agencia Nacional de Águas). 


\subsubsection{Zona de Convergência Intertropical e fenômeno ENSO}

As zonas de máxima insolação terrestre, que migram anualmente entre os hemisférios norte e sul na região equatorial causam uma região de menor pressão atmosférica. Isto acarreta na convergência de massas de ar intertropicais que carregam a umidade do Oceano Atlântico, proporcionando chuvas de monções na Amazônia (Vonhof \& Kaandorp, 2010). Essa zona de convergência de massas é chamada de Zona de Convergência Intertropical (Intertropical Convergence Zone, ITCZ), principal agente que define 0 atual clima sazonal amazônico, com períodos de baixa freqüência de chuva durante o inverno e alta freqüência no verão (Figura 6).

A cordilheira Andina exerce importante papel no regime de chuvas em escala continental (Bookhagen \& Strecker, 2010). A distribuição de chuvas na Amazônia é complexa e distinta para diferentes regiões (Vonhof \& Kaandorp, 2010). No entanto, o ciclo sazonal de chuvas é bem definido e atua em toda a área de captação do rio Xingu. Isto é reconhecido pela variação das chuvas e do nível d'água e vazão, registradas em estações pluviométricas e fluviométricas distribuídas na área de drenagem do rio Xingu.
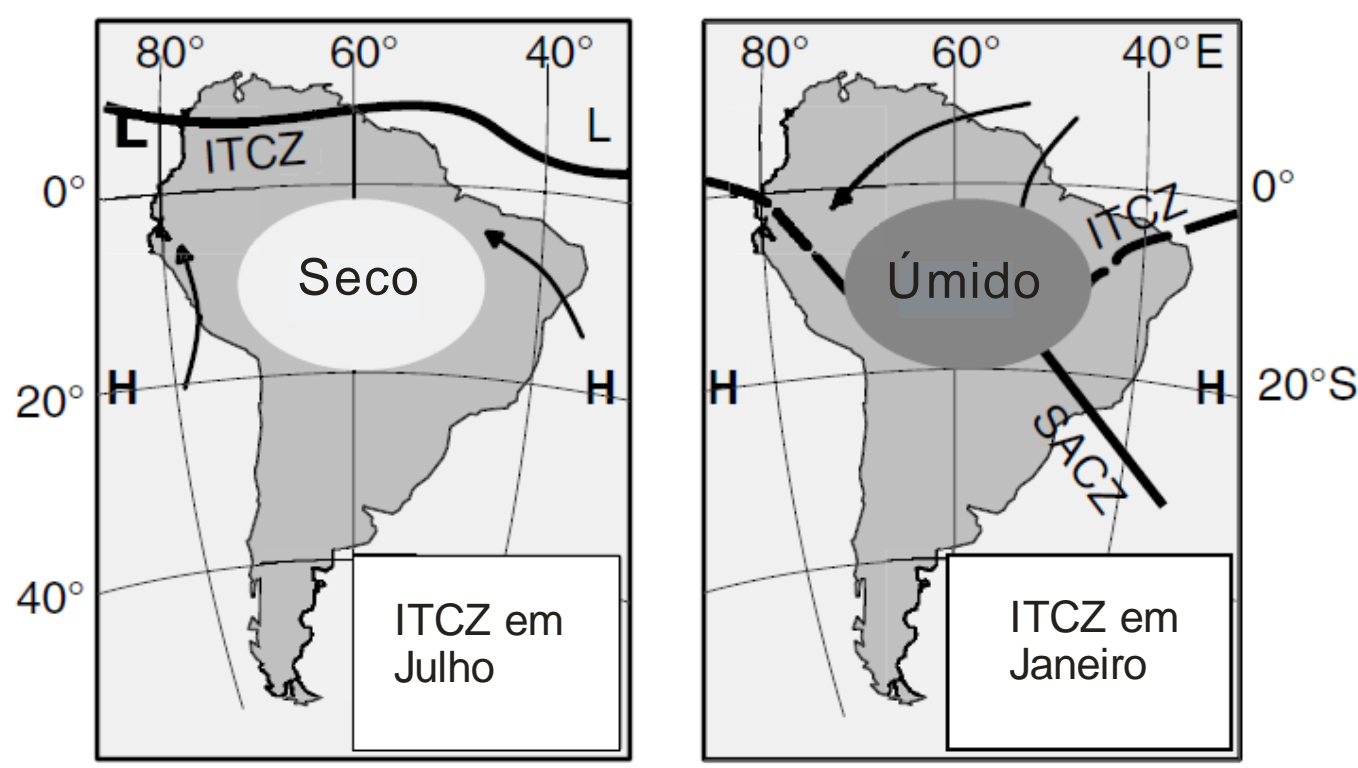

Figura 6. Representação esquemática da migração da ITCZ no Continente SulAmericano. Essa situação causa sazonalidade da precipitação da chuva, com maior freqüência de chuvas no verão e menor no inverno. SACZ: Zona de 
Convergência do Atlântico Sul (South Atlantic Convergence Zone). Extraído de Vonhof \& Kaandorp (2010).

Eventos que afetam a temperatura superficial dos oceanos também influenciam o regime de chuvas na Amazônia. O fenômeno El Niño (El Niño Southern Oscillation, ENSO), recorrente em dois a sete anos, representa o aquecimento anômalo das águas superficiais do Oceano Pacífico equatorial, que quando associado ao enfraquecimento dos ventos alísios causam mudanças climáticas em escala global (Figura 7). No Continente SulAmericano, seus principais efeitos são as chuvas catastróficas na costa peruana e precipitação sazonal anômala na Amazônia (Marengo, 2005). Essas mudanças na distribuição da temperatura no Oceano Pacífico equatorial também influenciam o fenômeno La Niña, resfriamento do Oceano Pacífico equatorial, que provoca a redução da taxa de precipitação na Amazônia (Bookhagen \& Strecker, 2010).
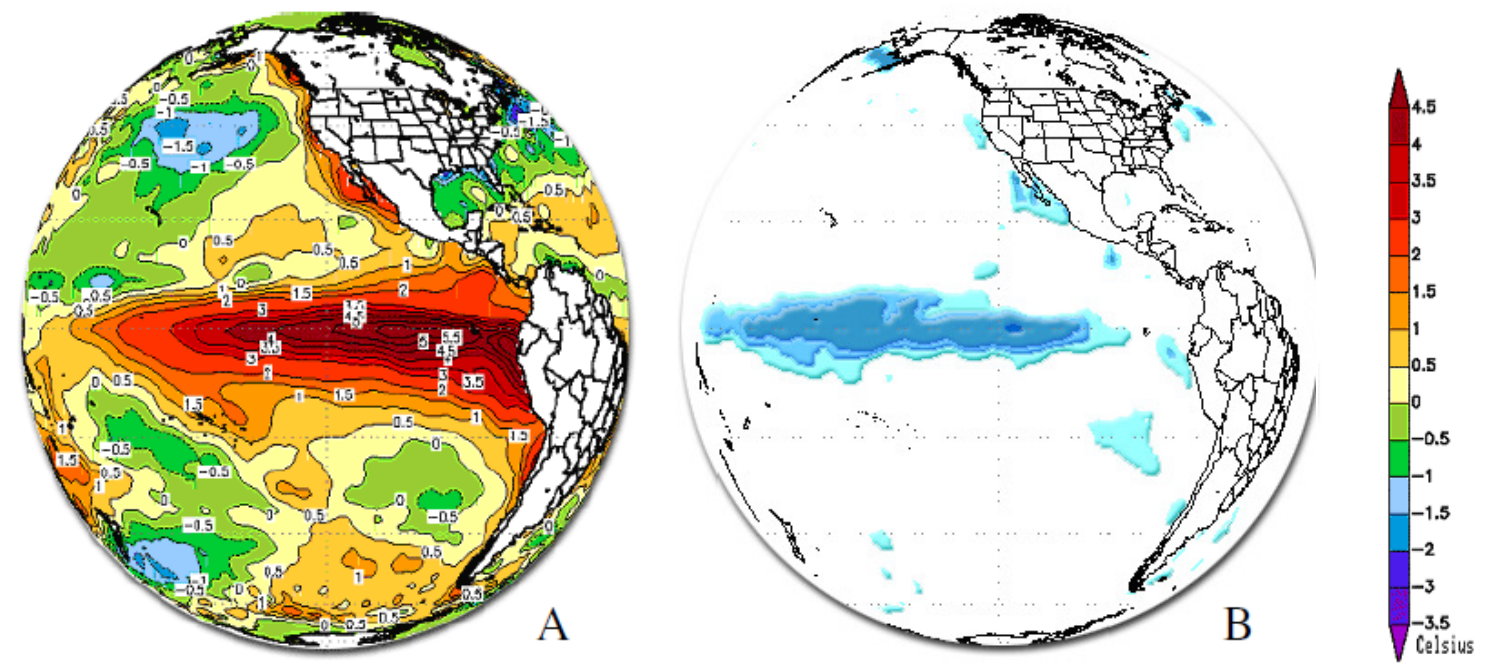

Figura 7. Anomalia da temperatura superficial do mar registrada em 1998 (A) e 1988 (B), representando os fenômenos El Niño e La Niña, respectivamente. Tons avermelhados indicam aquecimento acima da média e tons azulados, abaixo. Fonte: INPE.

Variações da ITCZ e o fenômeno ENSO compõem importante papel na evolução da paisagem amazônica, pois erosões em larga escala e 
sedimentação fluvial ocorrem tipicamente em eventos de precipitações extremas (Bookhagen \& Strecker, 2010).

\subsubsection{Paleopluviosidade e variações da Zona de Convergência Intertropical}

O paleoclima na região amazônica tem sido alvo de muitos estudos na última década (Baker et al., 2001a; Baker et al. 2001b; Behling et al., 2010; Bush et al., 2000; Bush et al., 2005; Cohen, 2005; Maslin \& Burns, 2000; Sifeddine et al. 2001; Van Breukelen et al., 2008). A maioria desses estudos é realizada em sedimentos de lagos, por não apresentar ambientes cársticos na região, os quais são baseados em indicadores paleoclimáticos derivados da mineralogia, geoquímica e biota presente em testemunhos de sedimentos. 0 estudo do paleoclima em lagos se distingue do estudo em espeleotemas por apresentar resolução geocronológica inferior e estar sob interferência direta da biota local, de eventos tectônicos e processos sedimentares locais e regionais, como transporte e área fonte de grãos, mudanças na rede de drenagem e variações no retrabalhamento e sedimentação lacustre. Estas interferências, se consideradas, dificultam a interpretação dos registros paleoclimáticos. Com intuito de amenizar essas incertezas, estudos de paleoclima em lagos utilizam dados da paleoecologia local, pois algumas espécies são sensíveis a alterações climáticas. No entanto, essas espécies podem ser sensíveis a outros fatores. Estudos de paleoclima que consideram uma grande variedade de espécies reduzem a incerteza de interpretações (Behling et al., 2010). A floresta Amazônica perduraria no mínimo durante os 11.000 anos, com adaptações a períodos secos e úmidos (Behling et al., 2010). Essa homogeneidade temporal deve garantir maior certeza em interpretações de dados paleoecológicos.

A América do Sul exerce importante papel no clima mundial e está sujeita a diversas variações e ciclos climáticos milenares (Baker et al., 2001a; Baker et al. 2001b; Behling et al., 2010), os quais tiveram importante papel para variações paleoclimáticas (Baker et al. 2001b). A falta de conhecimento desses ciclos climáticos e a baixa resolução das datações impossibilitam suas correlações com os depósitos sedimentares, impedindo a compreensão profunda de suas influências. Assim, a maioria dos estudos paleoclimáticos na 
Amazônia é focada nas variações glaciais e interglaciais (Van der Hammen \& Hooghiemstra, 2000).

Van Breukelen et al. (2008), em estudo de estalagmites na Amazônia Peruana (Figura 8), demonstram que o clima no Holoceno foi conduzido pela migração da ITCZ, que regula o regime de chuvas na região. Essas chuvas tiveram um acréscimo de até, aproximadamente, 30\% durante do Holoceno, enquanto que a temperatura permaneceu constante.

Muitos autores afirmam variações de precipitação na região amazônica durante o Holoceno, indicados por registros paleoecológicos (Behling et al., 2010, Bush et al., 2000 e Maslin \& Burns, 2000), valores de $\delta 180$ em espeleotemas (Van Breukelen et al., 2008) e registros sedimentológicos (Sifeddine et al., 2001; Bush et al., 2000). Segundo esses autores, o período de seca máxima está balizado entre 12.000 e 7.000 anos AP, com pico em 9.000 anos AP. De 9.000 a 4.000 anos AP ocorre acréscimo da precipitação média até o presente, com variações amplas e milenares de períodos secos e úmidos (Bush et al., 2000; Maslin \& Burns, 2000 e Van Breukelen et al., 2008). Sifeddine et al. (2001) sugerem que nesse período ocorre alta taxa de precipitação com aumento de transporte de sedimentos terrígenos na região da área de drenagem do rio Xingu entre 8.000 e 4.000 anos AP. Behling et al. (2010) também verificam máxima porcentagem de biota aquática entre $7.000 \mathrm{e}$ 6.000 anos AP na mesma região. Bush et al. (2000) apresentam dados testemunhos de sedimentos em um lago próximo à foz do rio Xingu onde há registro de produtos de precipitações sazonais extremas. Este autor atenta ao fato que entre 6.100 e 5.800 anos AP a configuração do padrão sazonal de chuvas era parecido com o atual.

O período de 4.000 anos AP até o presente é o mais úmido dos últimos 20.000 anos sendo marcado por variações menos amplas do regime de chuvas (Van Breukelen et al., 2008). Nesse período, Sifeddine et al. (2001) sugerem pulso com alta taxa de precipitação entre 2.700 e 1.500 anos AP. 


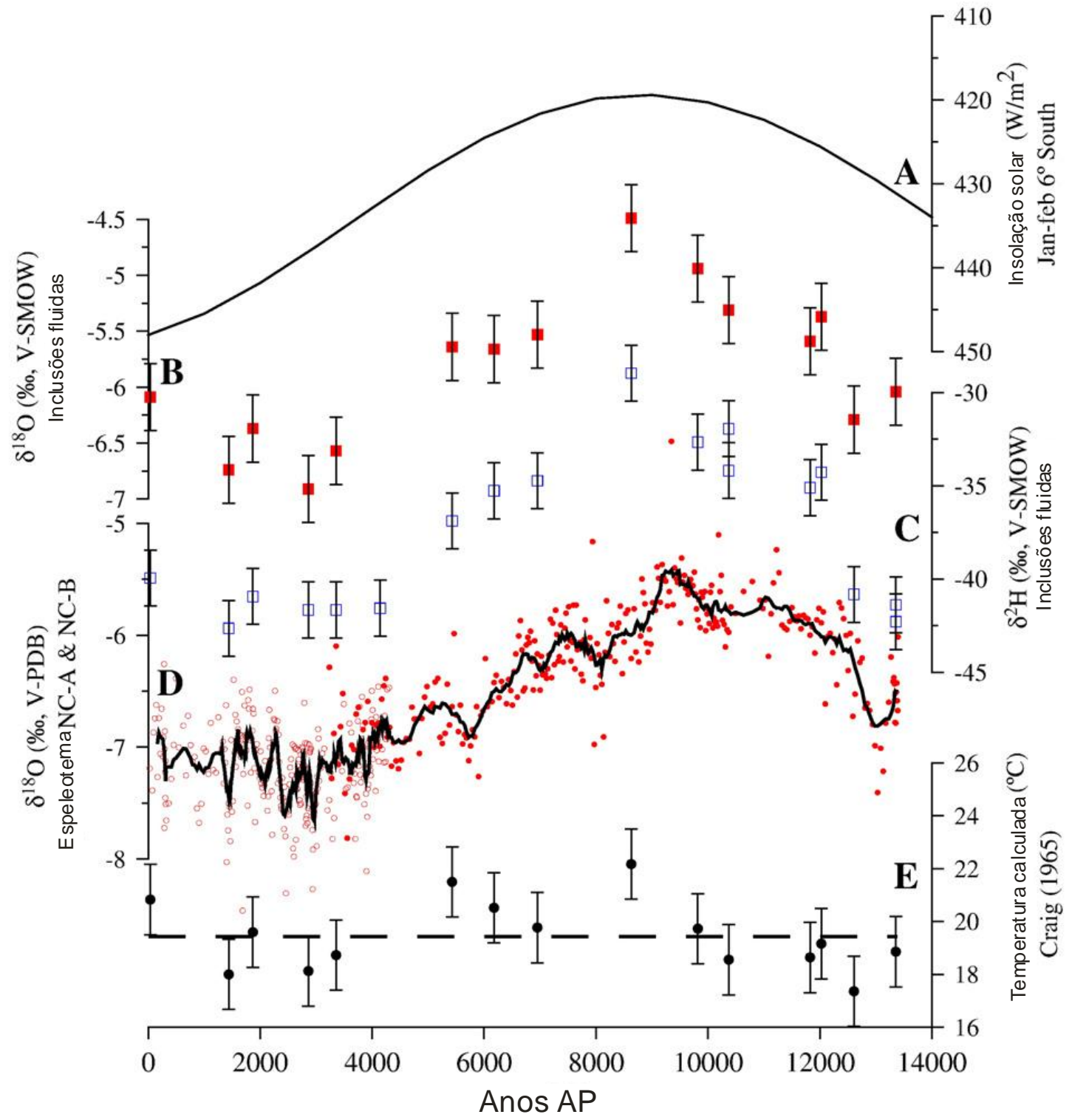

Figura 8. A) Curva de insolação em $6^{\circ}$ Sul (Laskar et al., 2004). B e C) Registros de isótopos de $\mathrm{O}$ e $\mathrm{H}$ em inclusões fluidas presentes em espeleotema (Van Breukelen et al., 2008). D) Isótopos de oxigênio em calcita de duas estalagmites diferentes (pontos abertos e fechados). A curva contínua representa a média desses dados. E) Temperatura estimada a partir de $\delta 180$ das inclusões fluidas e da calcita. A linha segmentada representa a média das temperaturas. Extraído de Van Breukelen et al. (2008). 


\subsubsection{Neotectônica}

\subsubsection{Campo de esforços atual}

Sismos respondem às tensões tectônicas exercidas, principalmente, pela dinâmica de placas tectônicas. Na região da Volta Grande do rio Xingu, são registrados seqüências de sismos com epicentros alinhados em duas direções, NNW e WNW (Figura 9). A direção WNW está de acordo com as lineações descritas na literatura (Rodriguez, 1993)

A Bacia do Amazonas está sob influência das tensões intraplacas resultantes da migração das placas de Nazca, Cocos e Caribe de encontro à Placa Sul Americana (Rodriguez, 1993). Há a possibilidade de movimentos isostáticos em todo o Cráton do Amazonas, explicados pelo acúmulo de carga sedimentar nas bacias do Acre, Solimões e Foz do Amazonas e erosão dos altos de Purus e de Gurupá (Rodriguez, 1993).

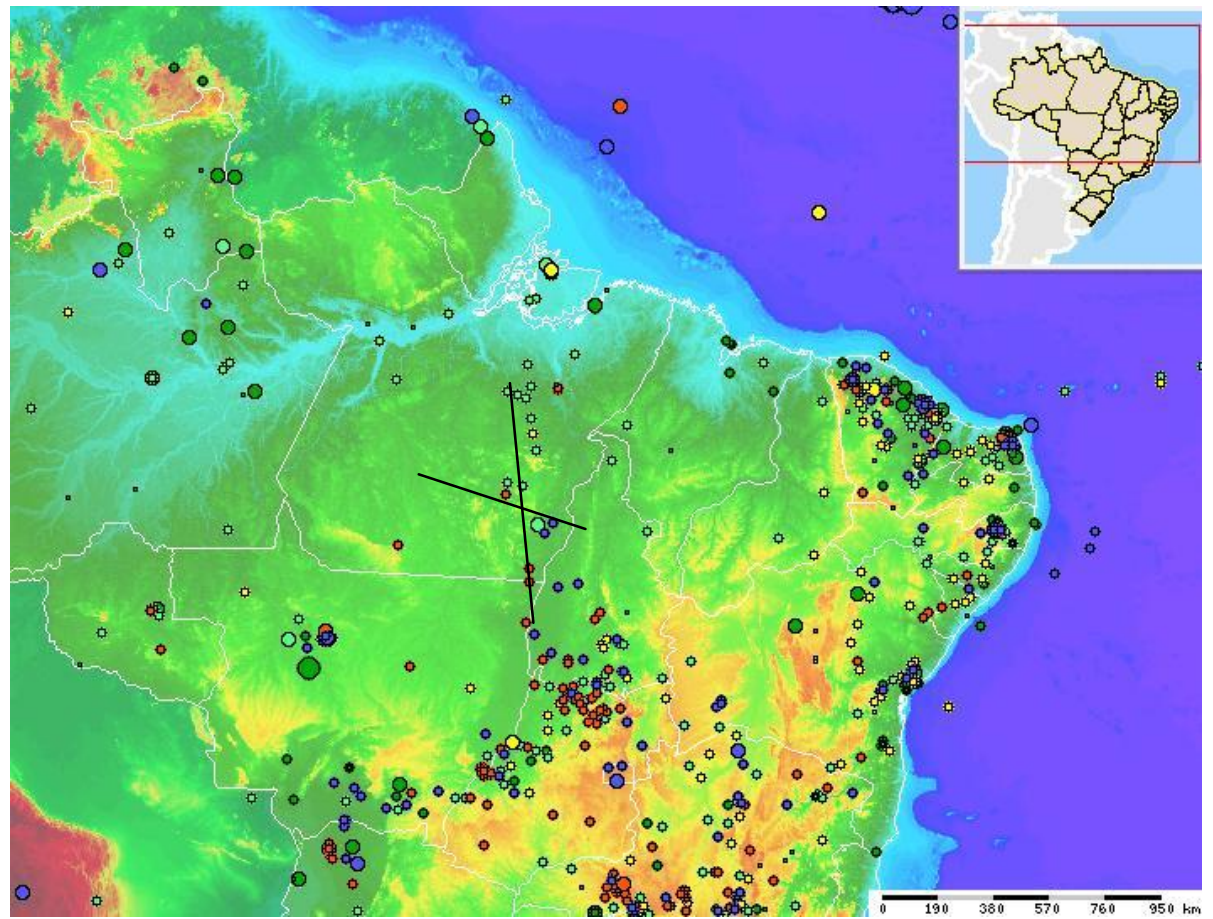

Figura 9. Mapa de sismicidade no Brasil. Pontos verdes correspondem aos sismos de 1720 a 1988, amarelos de 1988 a 1994, vermelhos de 1994 a 1998 e azuis de 1998 até o presente. As linhas correspondem os alinhamentos dos registros sísmicos. Disponível em www.sismo.iag.usp.br em Dezembro de 2011. 


\subsubsection{Estruturas tectônicas regionais}

O rio Xingu apresenta trechos encachoeirados com canais múltiplos retilíneos que se cruzam. Também é possível observar afluentes com canais de ângulos retos, possivelmente capturados por influência de estruturas tectônicas. Estas morfologias sugerem a influência da tectônica na morfologia da Volta Grande do rio Xingu.

Costa et al., (1996), em estudo de fotointerpretação realizado na região amazônica, demonstraram estruturas tectônicas extensionais do Mesozóico/Paleógeno e estruturas transcorrentes com movimentação em dois pulsos durante o Mioceno até o Recente. Essas estruturas (Figura 10) são interpretadas, muitas vezes, segundo a morfologia fluvial. Rios com trechos de canais afogados, como o baixo curso dos rio Xingu, Tapajós e Negro são interpretados como produtos de esforços extensionais. No entanto, esses canais são sempre barrados por acumulações de sedimentos quaternários. Próximo à foz do rio Xingu, entre Belo Monte e Porto de Moz, o canal deixa de ser encaixado e se torna largo e afogado. Costa et al. (1996) interpretam essa morfologia como resposta de uma junção tríplice do tipo T-T-R, cuja formação teria ocorrido durante o Quaternário (Figura 11). No entanto, o encontro com o rio Amazonas promove a formação de barragem natural do rio Xingu, com formação de barras longitudinais no rio Amazonas. Isto pode explicar a causa do afogamento, sem necessariamente evocar processos tectônicos. 


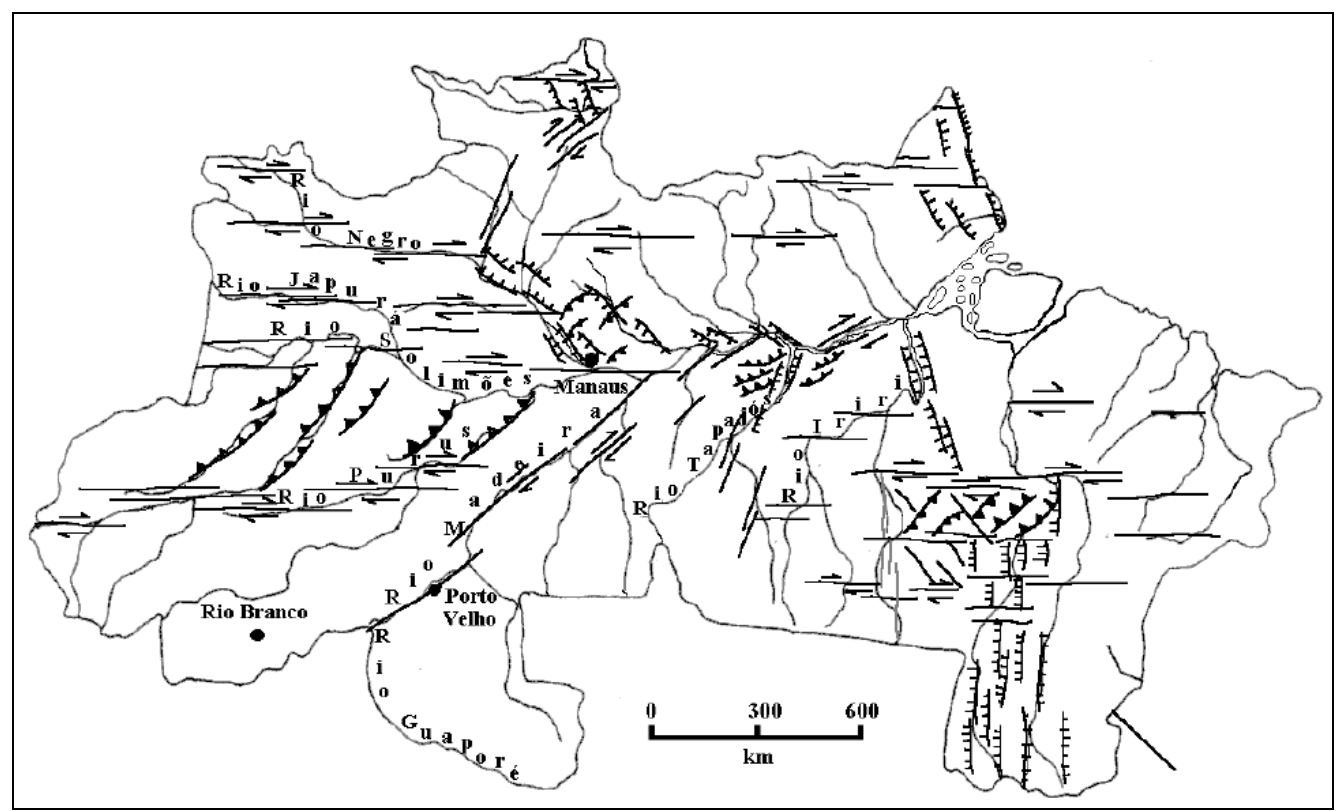

Figura 10. Falhas inversas, transcorrentes e normais inferidas a partir de fotointerpretação na região amazônica (Costa et al., 1996).

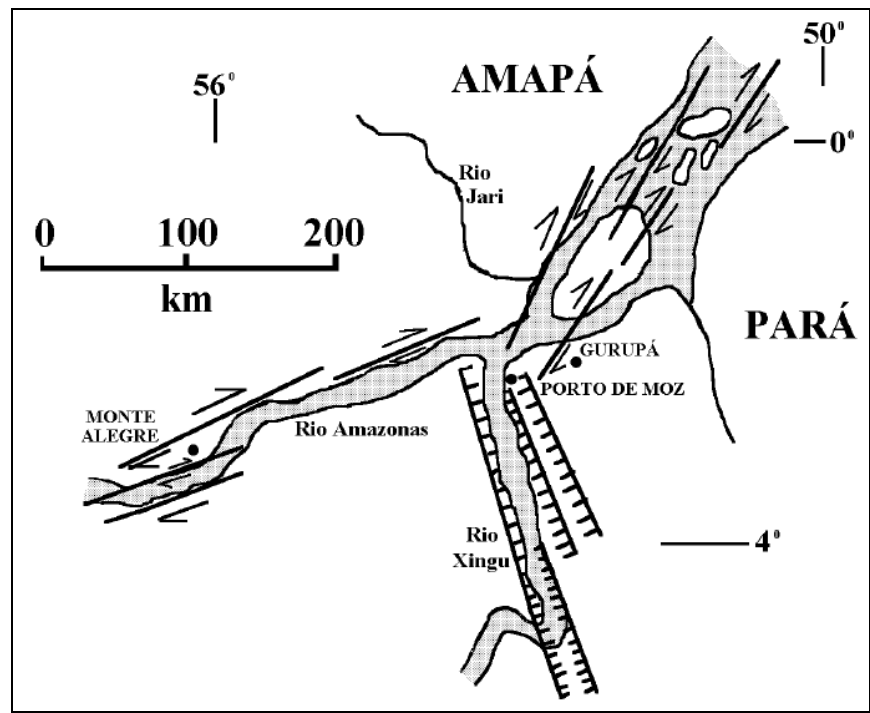

Figura 11. Junção tríplice quaternária do tipo T-T-R interpretada por Costa et al., 1996 na zona de confluência dos rios Xingu e Amazonas.

A morfologia distinta do canal do rio Xingu na região de Volta Grande correlaciona-se com lineamentos bem destacados nas direções N40W e N50E (Rodriguez, 1993). Estudo de isogradientes hidráulicos e lineamentos morfoestruturais apontam para compartimentação de blocos controlados por sistemas de lineamentos, os quais foram nomeados "Cachoeira Grande" e 
"Paxamba", de direção NW, e "Santo Antônio" e "Paratizinho", de direção NE (Figura 12) (Rodriguez, 1993).

Entre os lineamentos Cachoeira Grande e Paxamba, há indícios de movimentação tectônica ascendente, como conjuntos de falhas, registradas por métodos geofísicos, com rejeitos da ordem de 50 metros em unidades paleozóicas (Souza Filho et al., 1988). Além disso, ocorrem falhas de rejeitos centimétricos em leques aluviais e coluviais do Quaternário, com mesma direção das falhas observadas nas unidades inferiores. Isto indica reativação recente, que também é sugerida por depósitos aluviais em diferentes cotas, intercalados por lineamentos fotointerpretados, e pavimentos elevados de rochas do Complexo Xingu com feições de erosão fluvial do tipo "panela circular" (Rodriguez, 1993).

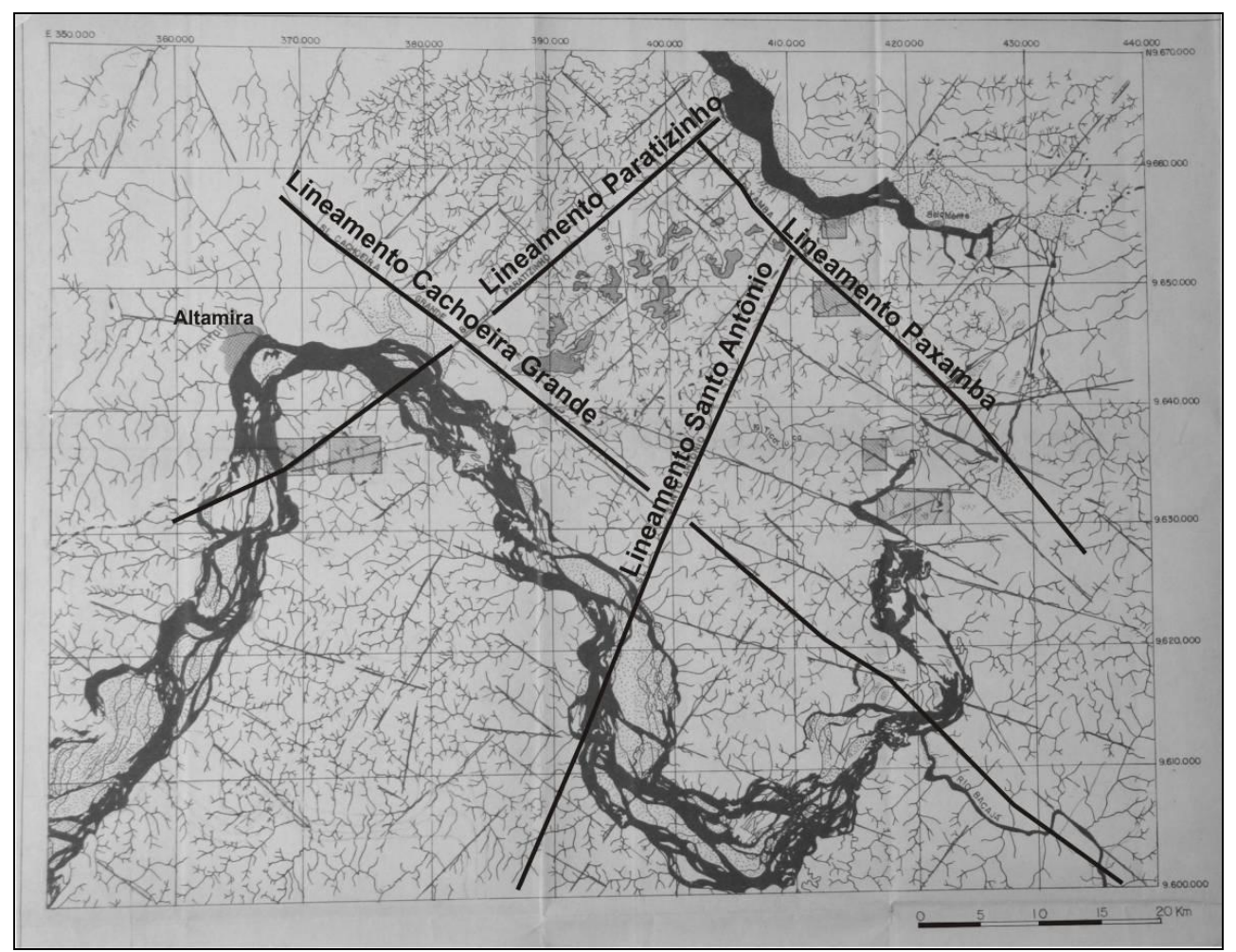

Figura 12. Principais lineamentos na Volta Grande do rio Xingu. Adaptado de Rodriguez (1993).

Formações lateríticas na região amazônica são datadas do Terciário Inicial e Terciário Tardio/Pleistoceno (Costa, 1991). As lateritas mais antigas indicam deslocamentos neotectônicos (Costa et al., 1996). Na região da Volta 
Grande, as formações lateríticas ocorrem em níveis topográficos de 10 a 144 m, sugerindo a incidência da neotectônica na região (Costa et al., 1996).

Segundo Rodriguez (1993), esforços trativos de direção N50W teriam configurado o curso do canal do rio Xingu desde o Terciário, quando teria ocorrido desvio do canal na região entre Altamira e Belo Monte, moldando a sua grande volta. Durante o Neógeno, a região entre os lineamentos Cachoeira Grande e Paxamba teria sofrido forte erosão, encaixando os canais em antigas estruturas no Complexo Xingu. No Pleistoceno teriam ocorrido reativações das estruturas tectônicas, causando falhas sin-sedimentares e segmentações parciais de depósitos fluviais. O Holoceno seria caracterizado pela deposição aluvial atual e o afogamento do trecho final do rio Xingu, entre Belo Monte e o rio Amazonas, produzindo naquela região, um desnível inferior a cinco metros, porém sem planícies de inundação expressivas.

Rodriguez (1993) aborda a neotectônica como principal agente da morfologia fluvial atual do rio Xingu. No entanto, não discute agentes climáticos, sedimentares ou morfodinâmicos, além de inferir idades por meio de correlações por não existir trabalhos específicos de datação. Assim como Costa et al., (1996), trata o trecho final do canal do rio Xingu como produto de esforços trativos, sem considerar o barramento natural do canal e influência da maré.

\subsection{Termoluminescência ( $T L$ ), luminescência opticamente estimulada (LOE)}

Luminescência é o fenômeno de emissão de luz quando certo material é exposto a um agente excitante. Para ocorrer esse fenômeno é necessário que estes sejam previamente expostos à radiação ionizante. O comprimento da luz emitida é característico da substância luminescente e não do agente excitante. Dependendo do tipo de agente excitante, a luminescência recebe nomes distintos: termoluminescência (TL) (excitação por aquecimento), luminescência ópticamente estimulada (LOE) ou fotoluminêscencia (excitação por luz), radioluminescência (excitação por radiação ionizante), catodoluminescência (excitação por feixe de elétrons), triboluminescência (excitação por energia mecânica), etc. 
É necessário distinguir a luminescência, principalmente a TL, da emissão incandescente. Esta última é o fenômeno de emissão luminosa por excitação térmica, próxima ao ponto de fusão do material excitado. A TL ocorre em temperaturas baixas em relação ao ponto de fusão do material. Além disso, na $T L$, uma vez aquecido o material, é necessária nova exposição à radiação ionizante para repetir o fenômeno luminescente.

$\mathrm{Na}$ TL e LOE a intensidade da emissão de luz é em geral proporcional à quantidade ou dose absorvida de radiação ionizante a que o material foi previamente exposto (McKeever, 1985).. Defeitos no retículo cristalino são responsáveis pelo sinal luminescente. Estes defeitos são formados pela incorporação de íons estranhos (impurezas) ou pela ausência dos íons principais (vacâncias) a determinado cristal. No caso do quartzo, estas impurezas são representadas principalmente por íons de alumínio e de elementos alcalinos, além de titânio, germânio e ferro (Preusser et al., 2009).

A teoria de banda dos sólidos é a base para elaboração de modelos que explicam a TL/LOE. A radiação ionizante é capaz de criar íons ou pares elétrons-buracos. Os elétrons movem-se livremente na banda de condução e podem ser capturados por armadilhas de elétrons durante a exposição do material à radiação ionizante. De modo análogo, os buracos movem-se na banda de valência e podem ser capturados em armadilhas de buracos. Essas armadilhas de elétron e de buracos são defeitos na rede cristalina que, em geral, são níveis localizados de energia na banda proibida, os quais são estáveis em temperatura ambiente (Figura 13). O fornecimento de energia térmica/óptica ao sistema de forma controlada aumenta a probabilidade dos portadores de cargas (elétrons/buracos) escaparem de suas respectivas armadilhas. Dessa forma, as cargas promovidas à banda de condução ou valência movem-se livremente pelo cristal podendo ser recapturadas ou recombinarem-se com sua parte contrária (Figura 14). Dessa recombinação resulta a liberação de energia através da emissão de luz, que é a TL/LOE. A intensidade do sinal luminoso emitida durante a estimulação térmica/óptica é proporcional ao número de recombinações e, portanto, proporcional ao número de elétrons nas armadilhas. 


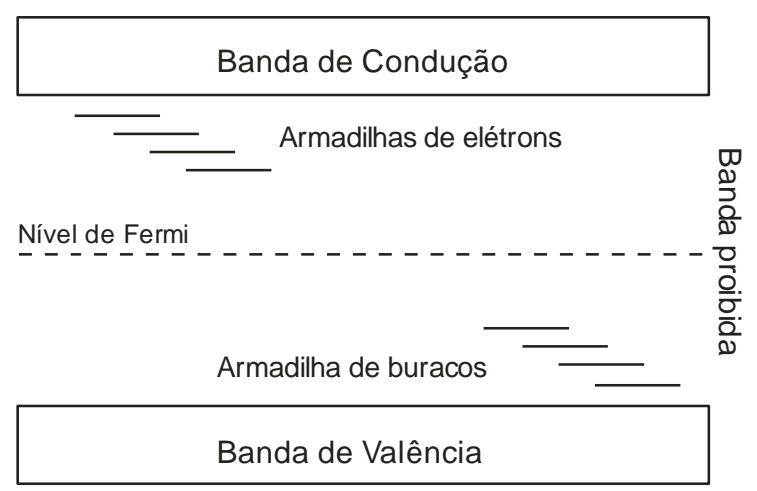

Figura 13. Esquema ilustrativo da teoria de bandas dos sólidos. O nível de Fermi delimita os níveis definidos como armadilhas e buracos. As linhas horizontais representam as posições das armadilhas na banda proibida. Este diagrama representa campos de energia e não a estrutura de um cristal ou a cinética dos pares elétrons-buraco.

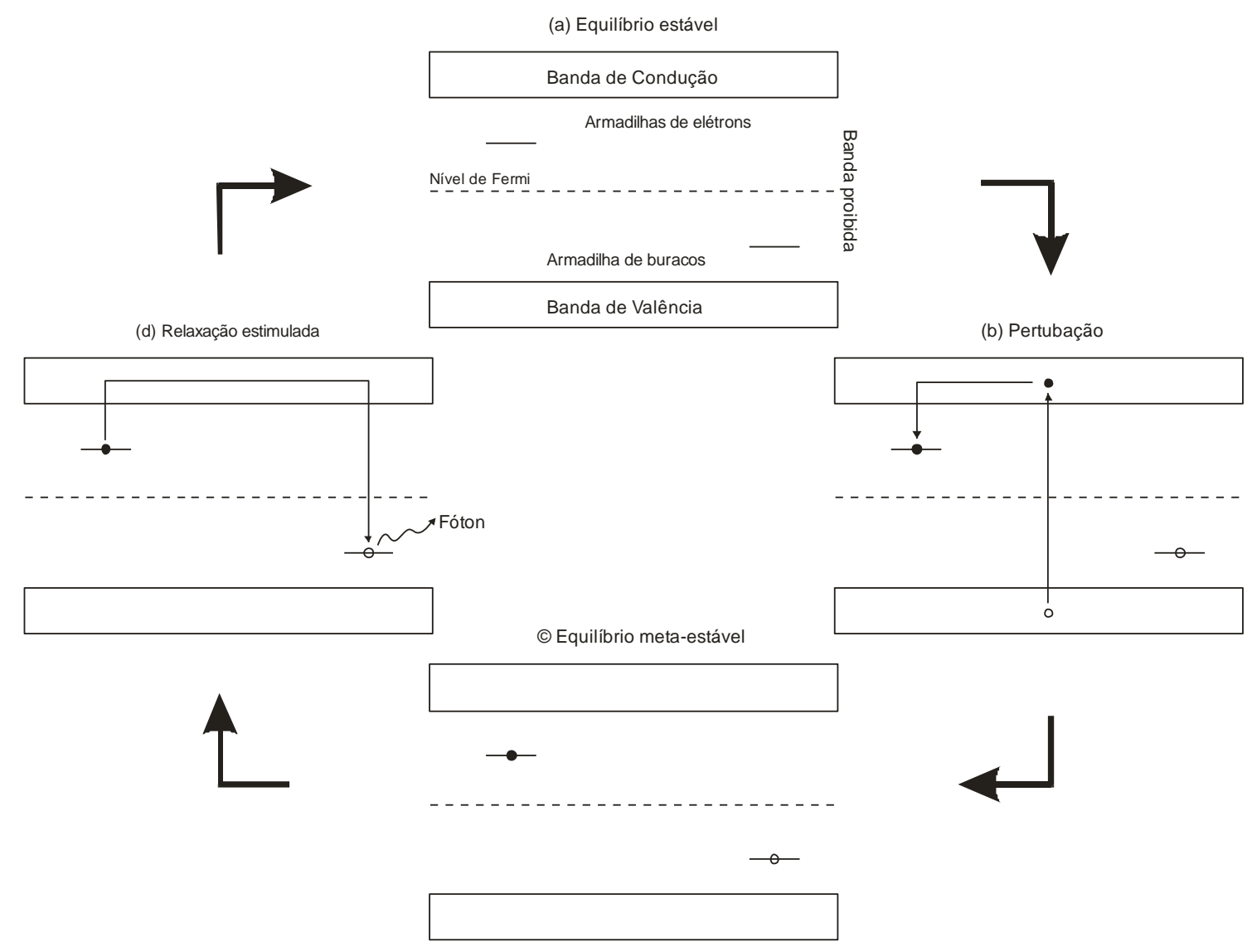

Figura 14. Esquema ilustrativo do processo de luminescência com base na teoria de bandas dos sólidos. Em (a) o cristal está em equilíbrio estável. Em (b) o cristal é exposto à radiação ionizante em (b), que produz pares elétronsburacos que são capturados por armadilhas. $O$ cristal permanece em um 
equilíbrio metaestável (c). A etapa (d) representa a estimulação térmica (TL) ou luminosa ( $\mathrm{LOE})$, que permite a saída de pares elétrons-buraco de suas respectivas armadilhas de modo a se recombinarem. Este esquema ilustra apenas uma das possibilidades do arranjo elétron-buraco. Baseado em Sawakuchi (2003)

A luz emitida no fenômeno da TL ou LOE pode ser detectada e amplificada através de uma fotomultiplicadora. As medidas TL e LOE são representadas por curvas da intensidade da luz emitida pelo cristal respectivamente em termos da temperatura ou tempo de estimulação (Figura 15). A sensibilidade TL/LOE equivale à intensidade de luz emitida em termos de determinada dose de radiação, indicando a capacidade de transformação da energia recebida em luz.
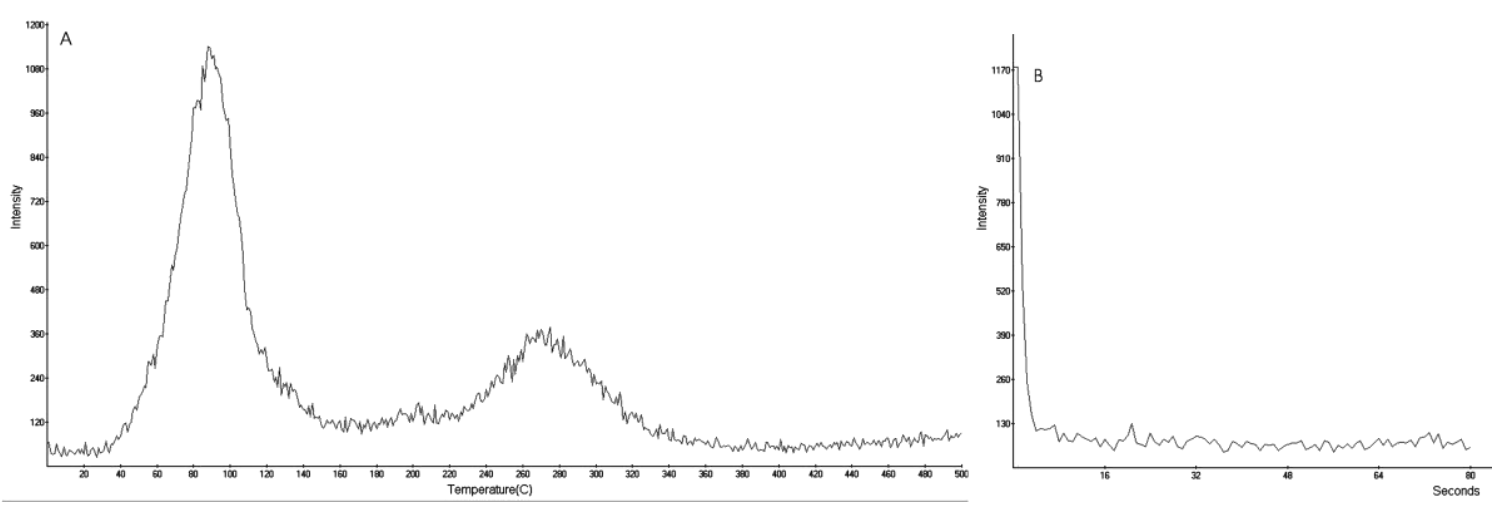

Figura 15 - Curvas TL (A), LOE (B) e de grãos de quartzo expostos à radiação beta (dose de 100Gy). A sensibilidade TL/LOE pode ser obtida pela integral da curva em certo intervalo de temperatura (TL) ou tempo de estimulação (LOE).

\subsection{Controles geológicos sobre a luminescência do quartzo}

O quartzo constitui componente abundante nos sedimentos terrígenos arenosos. A presença do quartzo em grande variedade de rochas ígneas, metamórficas e sedimentares, seu campo relativamente amplo de temperatura e pressão de cristalização e sua elevada estabilidade química e física ao intemperismo e processos sedimentares favorecem sua utilização como 
traçador em sedimentos arenosos. Diversos trabalhos procuraram utilizar feições texturais ou ópticas de grãos de quartzo como assinaturas de proveniência (Blatt \& Christie, 1963; Folk, 1974; Basu, 1985; Bernet \& Basset, 2005). Contudo, a sobreposição de características morfológicas, observadas em grãos de quartzo de origem distinta, dificulta a definição de assinaturas precisas de proveniência.

Apesar de ser composto quase que exclusivamente por $\mathrm{SiO}_{2}, 0$ quartzo pode incorporar impurezas, tais como íons $\mathrm{Al}^{3+}$ e $\mathrm{Ti}^{4+}$ em substituição ao $\mathrm{Si}^{4+}$. A substituição de $\mathrm{Si}^{4+}$ por $\mathrm{Al}^{3+}$ propicia a assimilação de íons alcalinos, tais como $\mathrm{Li}^{+}$e Na${ }^{+}$para manutenção do equilíbrio de cargas no retículo cristalino (Figura 16). O aumento da temperatura de cristalização e/ou da taxa de crescimento dos cristais de quartzo favorece a incorporação de íons estranhos ao retículo cristalino, que geram defeitos cristalinos responsáveis pela luminescência (Preusser et al., 2009; Sawakuchi et al., 2011a). Isto levou alguns autores a sugerirem o teor de Al em quartzo como geotermômetro (Dennen et al., 1970). No entanto, aquecimentos ocorridos após a cristalização (David \& Sunta, 1981; Bøtter-Jensen et al., 1995; Poolton et al., 2000; Koul, 2006) ou exposição a ciclos de irradiação-estimulação por luz ou calor (McKeever et al., 1996; Li, 2002; Moska \& Murray, 2006; Koul \& Chougaonkar, 2007) podem modificar a quantidade e distribuição de defeitos no retículo cristalino e alterar a luminescência do quartzo. A incorporação do tipo e quantidade de impurezas pelo quartzo dependerá também da disponibilidade destas impurezas no ambiente de cristalização. Assim, a TL/LOE do quartzo relaciona-se tanto à sua temperatura e ambiente de cristalização quanto à sua história termal e de irradiação.

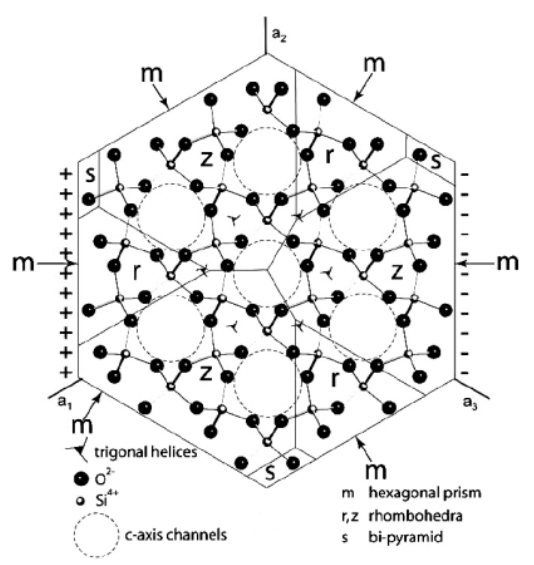




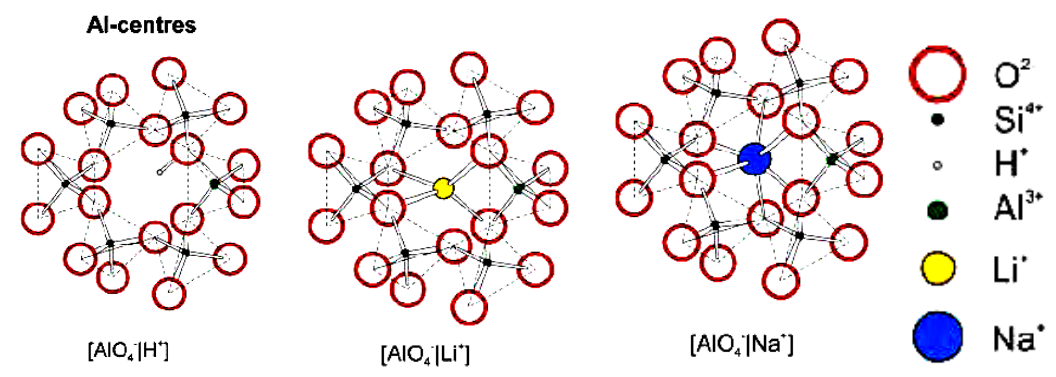

Figura 16. Estrutura cristalina do quartzo e centros de substituição de $\mathrm{Si}^{4+}$ por $\mathrm{Al}^{3+}$, os quais são responsáveis pela incorporação de $\mathrm{Li}^{+}$e $\mathrm{Na}^{+}$.

\subsection{Uso da LOE do quartzo para determinação do grau de retrabalhamento sedimentar}

Experimentos laboratoriais planejados para simular as condições de irradiação durante o soterramento e exposição à luz solar durante o transporte sedimentar têm demonstrado que a sensibilidade LOE é incrementada durante o período de residência dos grãos de quartzo em ambientes de sedimentação (Moska \& Murray, 2006; Pietsch et al., 2008). O incremento de sensibilidade, ocorrido durante o transporte sedimentar supera em diversas ordens de magnitude a sensibilidade LOE primária do quartzo. Isto permite diferenciar grãos de quartzo em termos do transporte sedimentar variável (Pietsch et al., 2008; Sawakuchi et al., 2011b) (Figura 17).

O estudo de areias do rio Castlereagh (Austrália) observou incremento significativo da sensibilidade LOE dos grãos de quartzo transportados por centenas de quilômetros (Pietsch et al., 2008). Segundo estes autores, o incremento da sensibilidade LOE das areias do rio Castlereagh ocorre tanto devido ao aumento da sensibilidade de grãos inicialmente luminescentes quanto à ativação do mecanismo de luminescência em grãos inicialmente nãoluminescentes. Sawakuchi et al. (2011b) também observou fenômeno semelhante de aumento da luminescência em grãos de quartzo das areias do rio Jacupiranguinha (Cajati, SP). No entanto, o aumento da sensibilidade LOE observado nas areias do rio Jacupiranguinha é significativamente menor que o observado no rio Castlereagh, se considerada a mesma distância de transporte. Esta variação no incremento da sensibilidade LOE observada nos rios Castlereagh e Jacupiranguinha é interpretada como resultado de 
diferenças da dinâmica destes dois rios (Sawakuchi et al., 2011b). O rio Castlereagh drena região semi-árida e possui fluxo efêmero enquanto que o rio Jacupiranguinha atravessa área úmida e apresenta fluxo permanente com água de elevada turbidez devido à alta carga de sedimentos em suspensão. A dinâmica sedimentar de rios efêmeros pode favorecer o incremento da sensibilidade LOE dos grãos de quartzo devido à sua maior capacidade de repetir ciclos de deposição, exposição à luz solar e remobilização dos seus sedimentos. Já os rios de áreas úmidas, os quais possuem fluxo permanente e águas turvas, dificultam a exposição solar dos grãos de quartzo. Além disso, o fluxo permanente dos rios de área úmida acarretaria em menor número de ciclos de soterramento e erosão dos sedimentos, considerando-se uma mesma distância de transporte. Assim, o melhor entendimento do efeito do transporte sedimentar sobre a sensibilidade LOE do quartzo permitiria sua utilização na caracterização da dinâmica sedimentar de sistemas fluviais ativos ou do registro geológico.

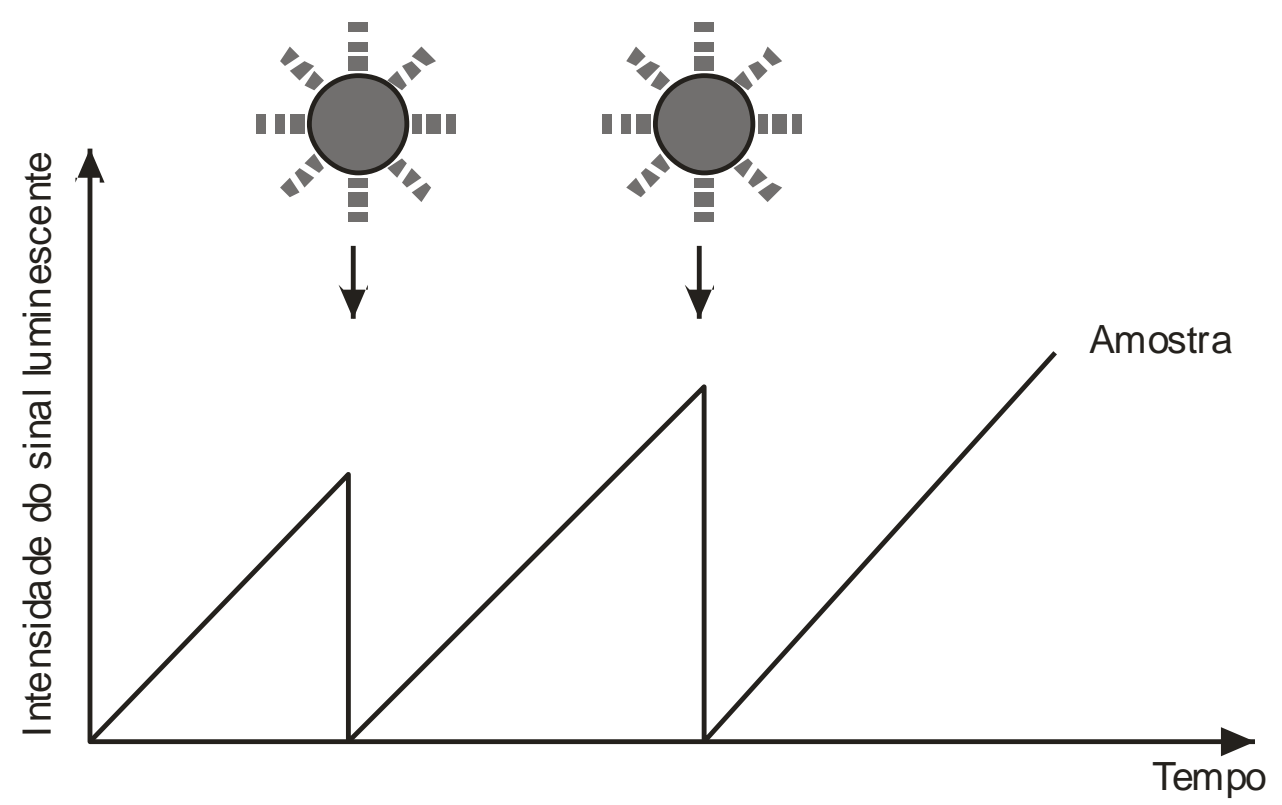

Figura 17. Intensidade do sinal luminescente pelo tempo de transporte. $O$ ganho do sinal luminescente do quartzo ocorre em períodos de soterramento. Quando o depósito é erodido, a exposição à luz solar provoca emissão de luz. Nota-se o ganho de sinal luminescente a cada ciclo de deposição-exumação. Extraído de Preusser et al. (2008). 


\section{Objetivos}

A relação entre a dinâmica fluvial e características granulométricas e de luminescência constitui a hipótese de trabalho desta dissertação, a qual visa o estudo da proveniência e transporte de sedimentos ao longo da Volta Grande do rio Xingu. Assim, supõe-se que mudanças nas características do regime fluvial, tais como vazão, sinuosidade e profundidade do canal impliquem em variações no modo de transporte dos sedimentos, as quais alteram a luminescência e granulometria dos sedimentos mediante alteração dos ciclos erosivo-deposicionais (irradiação-exposição solar). Para testar esta hipótese e compreender o modo de transporte de sedimentos na Volta Grande do rio Xingu, foram propostos os seguintes objetivos:

1. Caracterização geomorfológica e sedimentológica da Volta Grande do rio Xingu e seleção de pontos de amostragem.

2. Granulometria e análise de minerais pesados das amostras de areia coletadas nos diversos setores da Volta Grande do rio Xingu.

3. Medidas de sensibilidade da luminescência em grãos de quartzo e feldspato de amostras de sedimentos arenosos de diferentes fácies, coletadas em terraços, barras e canais fluviais.

4. Comparação entre padrões de variação espacial da granulometria e sensibilidade da luminescência e aspectos geomorfológicos e hidrológicos do rio Xingu na área de estudo

\section{Materiais e métodos}

\subsection{Análise geomorfológica}

Mapas geomorfológicos do trecho do rio Xingu selecionado para estudo foram elaborados a partir de imagens de satélite Landsat de 1990 e 2000, acessíveis no sítio eletrônico da NASA (National Aeronautics and Space Administration) e fornecidas pelo Instituto Nacional de Pesquisas Espaciais (INPE) e imagens de satélites disponíveis no Google Earth. Os mapas foram elaborados com auxílio de softwares de sistema de informação geográfica (ex. 
ArcGis 9.3). A confecção desses mapas auxilia na caracterização das barras fluviais quanto à geometria externa, área, vegetação, além de feições geomorfológicas, tais como lagos interiores, cordões de crescimento e praias. Os mapas geomorfológicos também auxiliaram na atividade de campo, quanto à seleção de pontos a serem amostrados.

Também foram obtidos perfis batimétricos transversais ao canal, por meio de sonar e GPS. Os perfis permitem comparar a morfologia do canal em diferentes seções e setores geomorfológicos do rio Xingu na área de estudo.

\subsection{Análise sedimentológica de campo e coleta de amostras}

Unidades geomorfológicas deposicionais ou erosivas definidas por sensoriamento remoto foram visitadas durante trabalho de campo para caracterização sedimentológica (descrição de fácies) e coleta de amostras. Quando possível (ex. barras e terraços fluviais), foi executada a análise de fácies em afloramentos naturais ou trincheiras abertas manualmente. A análise de fácies seguiu os preceitos de Walker \& James (1994). Os trabalhos de campo foram executados em períodos de seca, durante os dias 18 de Outubro e 02 de Novembro. Este período registra a época de máxima seca do rio Xingu, o que facilitou a abertura de trincheiras e coleta de amostras superficiais em barras e terraços. $O$ transporte até os pontos de estudo e amostragem foi realizado por barco de pequeno porte ("voadeiras"). As amostras de sedimentos de canais foram coletadas com amostrador do tipo Van-veen, que permitiu a coleta de amostras de sedimentos superficiais submersos.

Foram coletadas 119 de sedimentos de barras e terraços do rio Xingu expostos durante o período de seca. O mapa com a localização dos pontos amostrados é apresentado na Figura 18. 


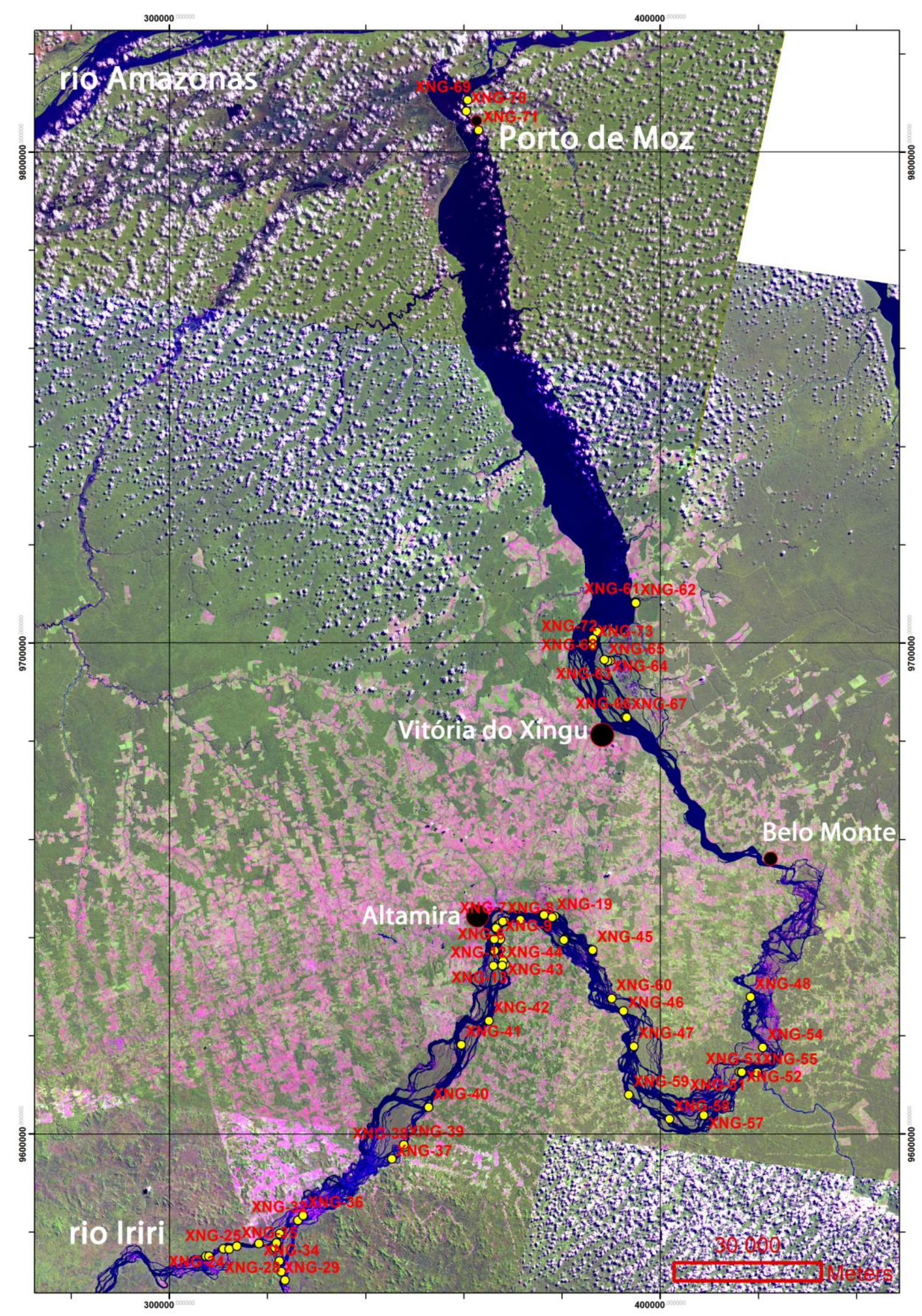

Figura 18. Localização dos pontos de coleta de amostros de sedimento no rio Xingu. 


\subsection{Análise granulométrica}

As análises granulométricas foram realizadas em equipamento Malvern, que faz medidas dos diâmetros de grãos por método de difração em feixe de laser. Dados de granulometria foram comparados com dados de luminescência com intuito de estabelecer possíveis correlações entre grau de retrabalhamento/proveniência e textura dos sedimentos. O procedimento de medida granulométrica envolveu as seguintes etapas:

1. Secagem das amostras em estufa.

2. Peneiramento em trama de $1 \mathrm{~mm}$ devido às restrições do equipamento para medir granulações maiores.

3. Dispersão de alíquota específica (grãos com diâmetro $<1 \mathrm{~mm}$ ) em água com pirofosfato de potássio para desagregar partículas finas.

4. Cinco tomadas de medidas granulométricas a úmido no granulômetro Malvern.

\subsection{Análise de minerais pesados}

Amostras de fácies arenosas foram submetidas à separação de minerais pesados para análise de proveniência sedimentar. A fração areia fina $(0,125-$ $0,250 \mathrm{~mm}$ ) dos grãos de minerais pesados foi analisada ao microscópio óptico de luz transmitida para identificação e descrição dos minerais pesados transparentes e não-micáceos. Ao todo, foram analisadas 41 amostras de barras e praias das margens dos rios Xingu e Iriri. Para isto, realizaram-se as seguintes tarefas:

1. Peneiramento a úmido com obtenção da fração areia fina $(0,125$ $0,250 \mathrm{~mm})$. O peneiramento a úmido visa eliminar a fração lamosa.

2. Separação de minerais pesados em solução de metatungstato de lítio (densidade $=2.85 \mathrm{~g} / \mathrm{cm}^{3}$ ).

\subsection{Medidas de sensibilidade da luminescência}


As medidas de sensibilidade da luminescência foram realizadas em 40 amostras de sedimentos arenosos de praias e dunas subaquosas e barras ativas. As amostras foram peneiradas para aquisição do intervalo granulométrico entre 180 e $250 \mu \mathrm{m}$. Posteriormente, foram submetidas aos seguintes processos para separação de grãos de quartzo e feldspato:

1. Ataque com $\mathrm{HCL} 3.75 \%$ para eliminação de carbonatos.

2. Ataque com $\mathrm{H}_{2} \mathrm{O}_{2}$ para eliminação de matéria orgânica.

3. Separação de minerais pesados em solução de metatungstato de lítio (densidade $=2.85 \mathrm{~g} / \mathrm{cm}^{3}$ ).

Para cada amostra foram realizadas medidas de luminescência em 12 alíquotas de grãos com igual volume por amostra. Alíquotas dispersas em placas de aço foram submetidas à seguinte seqüência de medidas:

1. Bleaching (esvaziamento do sinal luminescente) por $100 \mathrm{~s} \mathrm{em}$ temperatura ambiente com uso de LED azul ( $90 \%$ de potência).

2. Aplicação de dose (10Gy) de radiação beta (fonte ${ }^{90} \mathrm{Sr} /{ }^{90} \mathrm{Y}$ com taxa de $0,088 \mathrm{~Gy} / \mathrm{s}$ ).

3. Medida $\mathrm{TL}$ até $190^{\circ} \mathrm{C}$ com taxa de $5^{\circ} \mathrm{C} / \mathrm{s}$ e permanência em $190^{\circ} \mathrm{C}$ por 10 segundos. $\mathrm{O}$ aquecimento a $190^{\circ} \mathrm{C}$ também teve como objetivo eliminação de componentes LOE instáveis.

4. Medida LOE com estímulo por infravermelho (IR-LOE) durante 300 s à temperatura de $60^{\circ} \mathrm{C}$ com taxa de $5^{\circ} \mathrm{C} / \mathrm{s}$ e potência do diodo a $90 \%$. A medida de IR-LOE apenas registra sinal luminescente do feldspato e não atua sobre grãos de quartzo. Tem como objetivo estimar a proporção e sensibilidade dos grãos de feldspato em relação ao quartzo, além de eliminar o sinal LOE de grãos de feldspato para medida subsequente do quartzo.

5. Medida LOE com estímulo por luz azul (ALED-LOE) por 100 s à temperatura de $125^{\circ} \mathrm{C}$ com taxa de $5^{\circ} \mathrm{C} / \mathrm{s}$ e potência do LED em $90 \%$.

6. Medida LOE com estímulo por luz azul por 100s a temperatura de $125^{\circ} \mathrm{C}$ com taxa de $5^{\circ} \mathrm{C} / \mathrm{s}$ e potência do LED em $90 \%$. Esta segunda medida LOE é realizada para medir o ruído de fundo (background) da 
estimulação por luz azul e avaliar a presença de eventual sinal residual.

As medidas LOE foram efetuadas em equipamento Risø DA-20 TL/OSL systems do Laboratório de Espectrometria Gama e Luminescência (Legal) do Instituto de Geociências da USP. Este equipamento possibilita a irradiação, tratamento térmico e medidas de luminescência de modo automatizado em conjuntos de até 48 alíquotas de minerais em grãos. As medidas foram realizadas em 24 alíquotas intercaladas nas 48 posições do leitor de luminescência, a fim de minimizar possíveis interações (cross-talking) de radiação e estimulação entre amostras vizinhas.

A sensibilidade LOE, foi representada pela integral da parte inicial (dominada por componentes LOE rápidos) ou das curvas LOE ou pela integral da curva LOE total. A sensibilidade TL foi medida pela integral das da curva TL entre as temperaturas de $25^{\circ} \mathrm{C}$ (temperatura ambiente) e $190^{\circ} \mathrm{C}$. O sinal $T L$ até $190^{\circ} \mathrm{C}$ é dominado pelo quartzo e está relacionado à sua proveniência e ciclos de exumação/deposição.

Para medidas de IR-LOE foram calculadas integrais entre 0 e 300 s e para IR-Fast, entre 0 e 3s. Nas Medidas de ALED-LOE foram calculadas integrais entre 0 e 100 s e para OSL-Fast, 0 e 4s.

As amostras foram classificadas de acordo com os setores geomorfológicos definidos para o rio Xingu na área de estudo. Os dados de sensibilidade TL e sensibilidade LOE foram compilados em planilhas Excel e Origin para análise estatística e elaboração de gráficos.

\subsection{Análise estatística dos dados}

Os dados de granulometria e sensibilidade LOE e TL foram agrupados em planilhas para cálculo de estatísticas descritivas e elaboração de gráficos boxplot. Os dados de luminescência e granulometria foram categorizados em termos dos setores geomorfológicos definidos para o rio Xingu na área de estudo. Gráfico de dispersão foi utilizado para avaliar correlação entre medidas de sensibilidade LOE/TL e granulometria. 


\section{Resultados}

\subsection{Geomorfologia}

A formação e crescimento das barras de sedimentos do rio Xingu estão relacionados às variações do regime de fluxo, aporte sedimentar e fisiografia do curso do rio. O mapa da Figura 19 demonstra setores que determinam crescimento diferenciado das barras do rio Xingu, quanto à forma, tamanho e densidade. É possível separar sete setores geomorfológicos ao longo do canal do rio Xingu na área estudada.

O setor 1 é representado pela foz do rio Xingu no rio Amazonas. Este setor é caracterizado por conter grandes barras alongadas, com área média de 23.300.000 m², e separadas por canais múltiplos e largos.

O setor 2 é caracterizado por canal único largo (até $13 \mathrm{Km}$ de largura), com morfologia sugestiva de afogamento e ausência de barras aflorantes. Este setor apresenta tributários de pequeno porte e margem dominada por escarpas erosivas, com depósitos de escorregamento. Esta seção do rio é influenciada pelo regime de maré devido às baixas cotas topográficas $(\sim 20 \mathrm{~m})$ e proximidade à foz do rio Amazonas. As margens deste setor são dominadas por praias influenciadas por maré. Há pequenos tributários ao longo deste setor que geram depósitos do tipo delta com dimensão de até 15 por $6 \mathrm{Km}$. Em campo, foram observados raros depósitos de barras longitudinais subaquosas que são expostos no período de seca do rio Xingu.

O setor 3 apresenta canal único encaixado, que deságua no canal largo afogado representado pelo setor 2 . Isto propicia a formação de complexo de barras similar à delta, com arquipélago de ilhas em média com $1.860 .000 \mathrm{~m}^{2}$ de área.

O setor 4 é caracterizado por canais múltiplos retilíneos, com corredeiras, encaixados em sistemas de fraturas. Este setor é predominantemente erosivo e não há formação de barras arenosas.

O setor 5 apresenta 935 barras aflorantes com área em média de $340.000 \mathrm{~m}^{2}$. Isto indica grande capacidade de retenção de sedimentos. É composto por canais múltiplos largos, rasos $(\sim 1 \mathrm{~m})$ a profundos $(\sim 20 \mathrm{~m})$, controlados, muitas vezes por sistemas de fraturas. Porém, estes canais não 
são encachoeirados. Também ocorrem trechos onde o canal é único com ausência de barras. Em região mais ao sul deste setor, os canais são definidos por sistemas de fraturas e afloramentos do substrato rochoso que propiciam acúmulo de sedimentos.

Os setores 6 e 7 são relativos ao rio Xingu a montante da foz do rio Iriri e o rio Iriri, respectivamente. Nestas porções, as barras são formadas predominantemente pelo acúmulo de sedimentos sobre o substrato rochoso e condicionadas por sistemas de fraturas.

Os perfis batimétricos foram realizados em trechos com estreitamento do canal nos setores 2, 3 e 5 . Estes trechos apresentam profundidade superior a $15 \mathrm{~m}$ e escalonamento com patamar ou canais subordinados (Figura 20). Porções de alguns perfis apresentam assimetria com lado aproximadamente vertical, sugestivo de escarpa falha ou fratura, e fundo do canal segmentado por variação da profundidade.

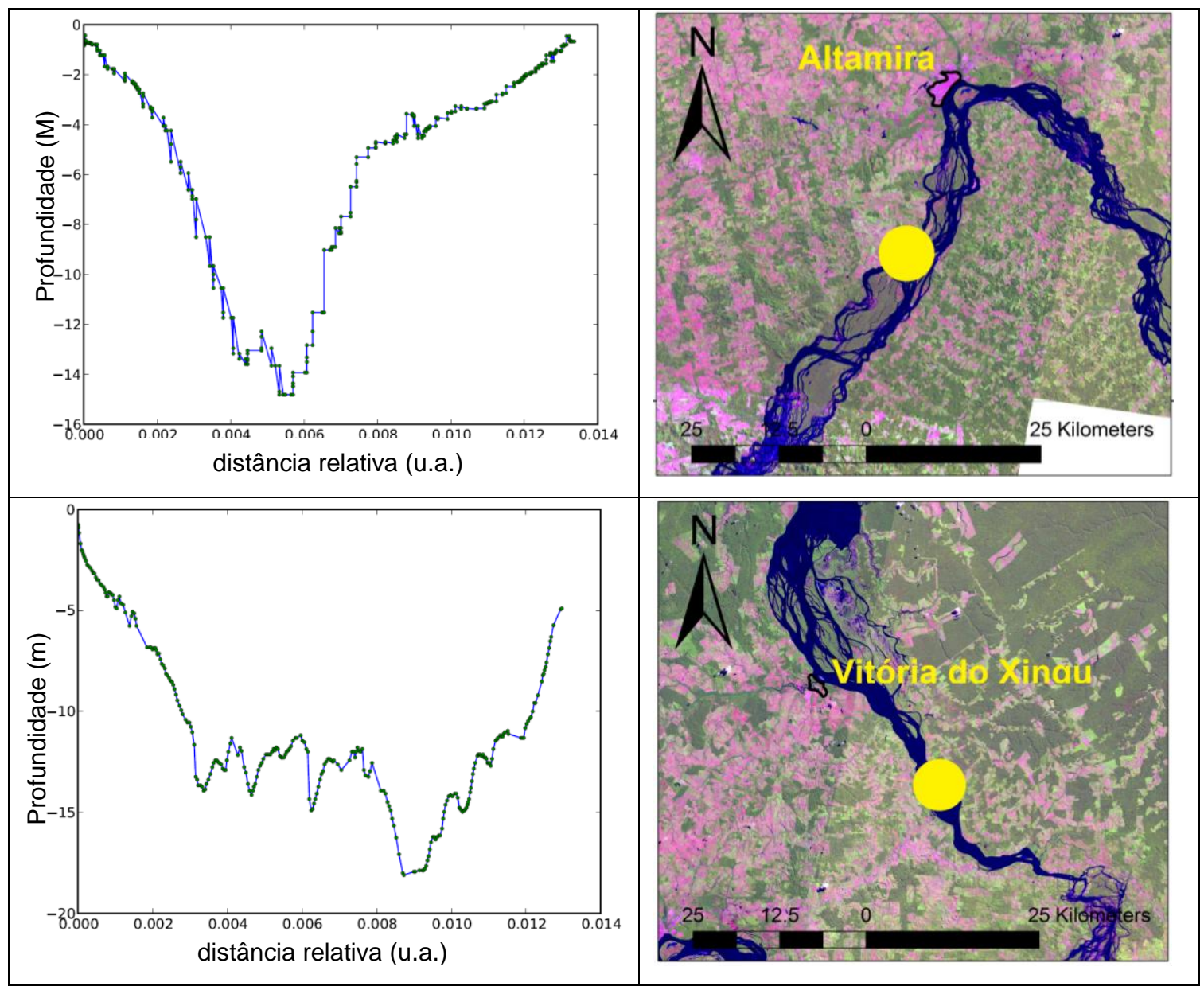




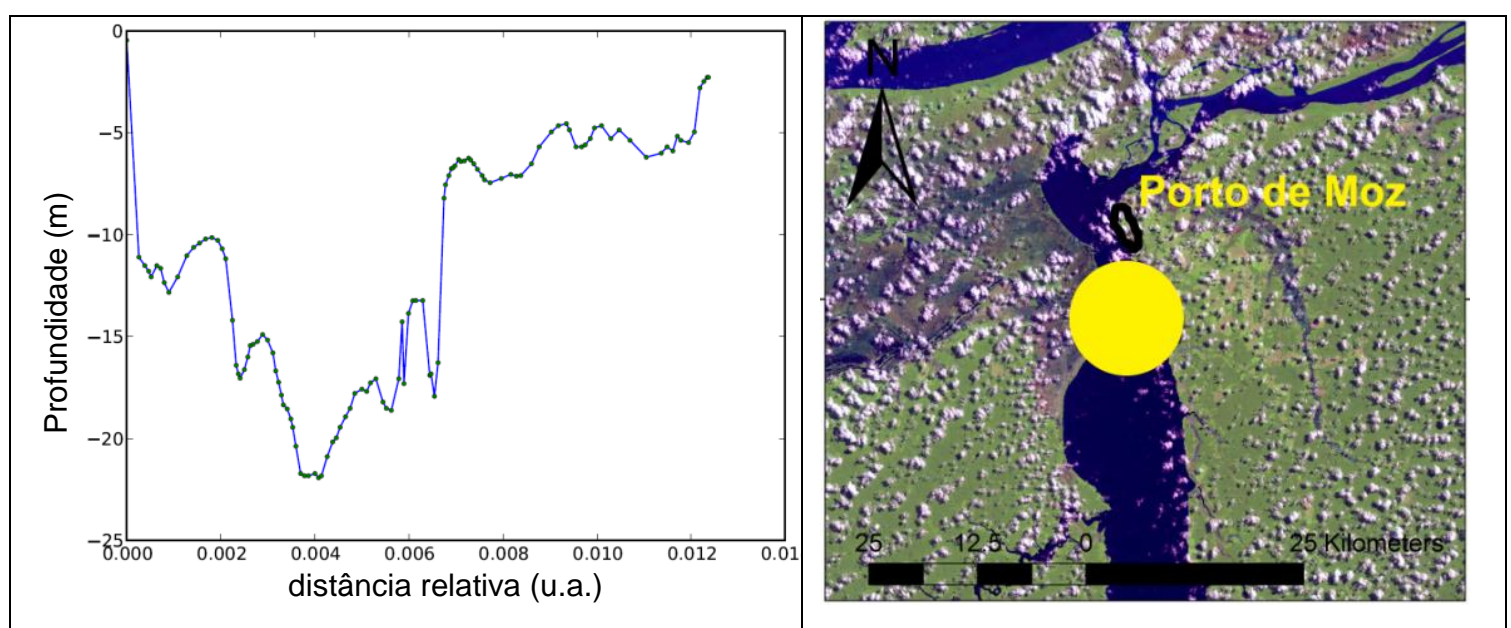

Figura 20. Perfis batimétricos e sua localização no rio Xingu. Os perfis foram obtidos durante o periodo de seca. 


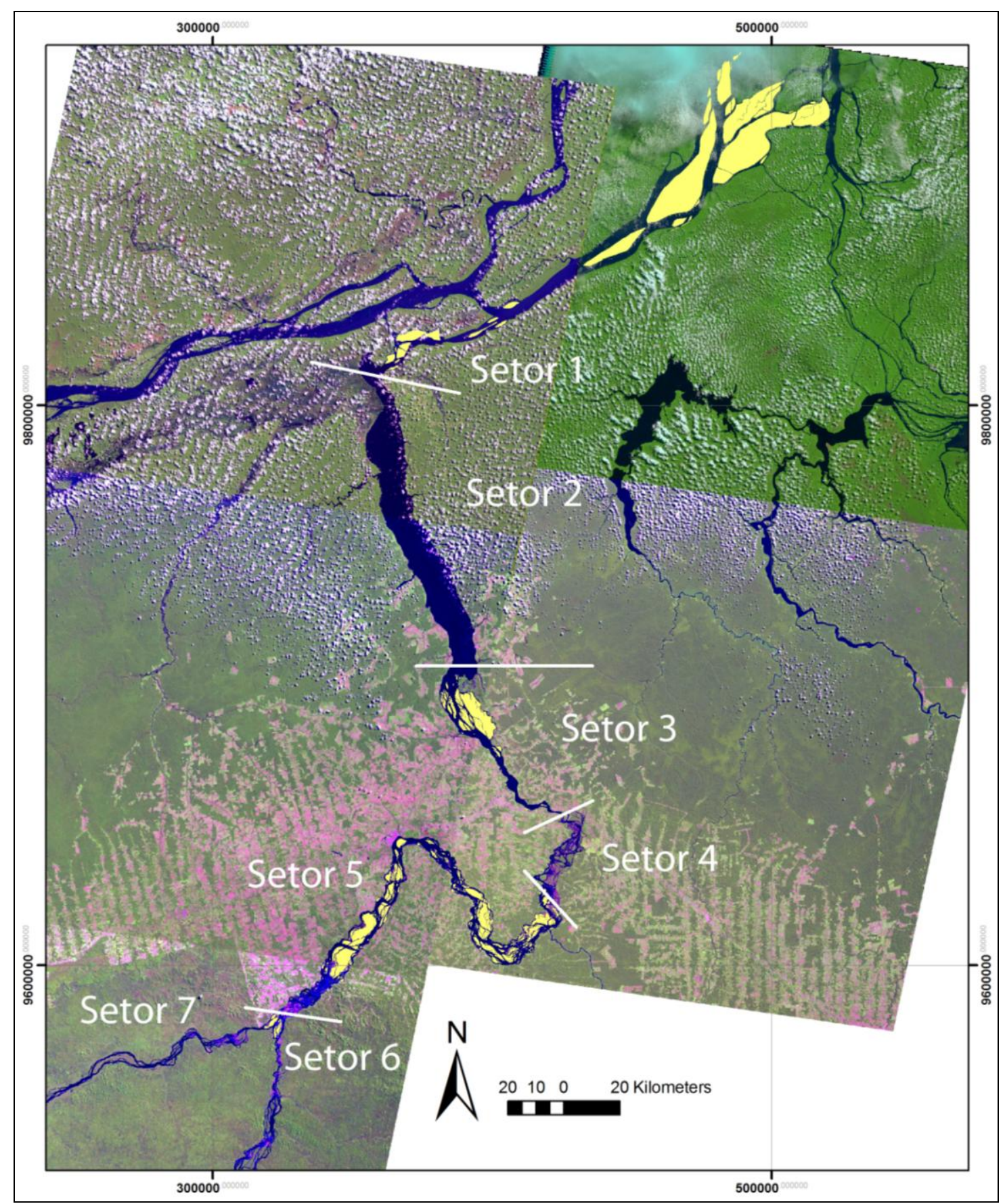

Figura 19. Mapa geomorfológico com divisão de setores definidos pela morfologia das barras e do canal do rio Xingu.

\subsection{Análise de fácies}

Foram identificadas e interpretadas três fácies sedimentares descritas em afloramentos nos terraços ou barras fluviais do rio Xingu. Estas fácies são descritas a seguir e ilustradas na Figura 21. 
Lm (Lama maciça) - Esta fácies é representada por lama argilosa a arenosa branco acinzentada com manchas alaranjadas, maciça, compacta ou pouco consolidada. Por vezes, ocorrem horizontes pedogênicos e matéria orgânica. Está fácies está associada às barras ou margens estáveis e densamente vegetadas. É interpretada como depósitos de decantação durante a cheia do rio, em zona onde raízes e vegetação rasteira proporcionam a deposição dos sedimentos finos.

AFMc (Areia fina a média com estratificação cruzada) - Fácies representada por areia fina a média, laranja, inconsolidada com estratificação cruzada tabular em séries decimétricas. Por vezes, ocorrem grânulos esparsos de laterita. Está fácie está associada a depósitos de praia e barras ativas pouco ou não vegetadas. É interpretada como depósitos de dunas subaquáticas de crista reta a sinuosa, em regime de fluxo inferior.

AMGc (Areia média a grossa com cascalho e estratificação cruzada) Está fácies é representada por areia média a grossa, cascalhosa, cinza ou laranja, pouco consolidada com séries decimétricas de estratificação cruzada tabular ou acanalada. Geralmente, há grânulos e/ou seixos esparsos, principalmente de laterita. Podem ocorrer intercalados com areia média. Está associada a depósitos de dunas com comprimento de onda da ordem de 10 $15 \mathrm{~m}$, que migram durante a cheia do rio. É interpretada como depósitos de dunas subaquáticas de crista reta a sinuosa formadas em regime de fluxo inferior.
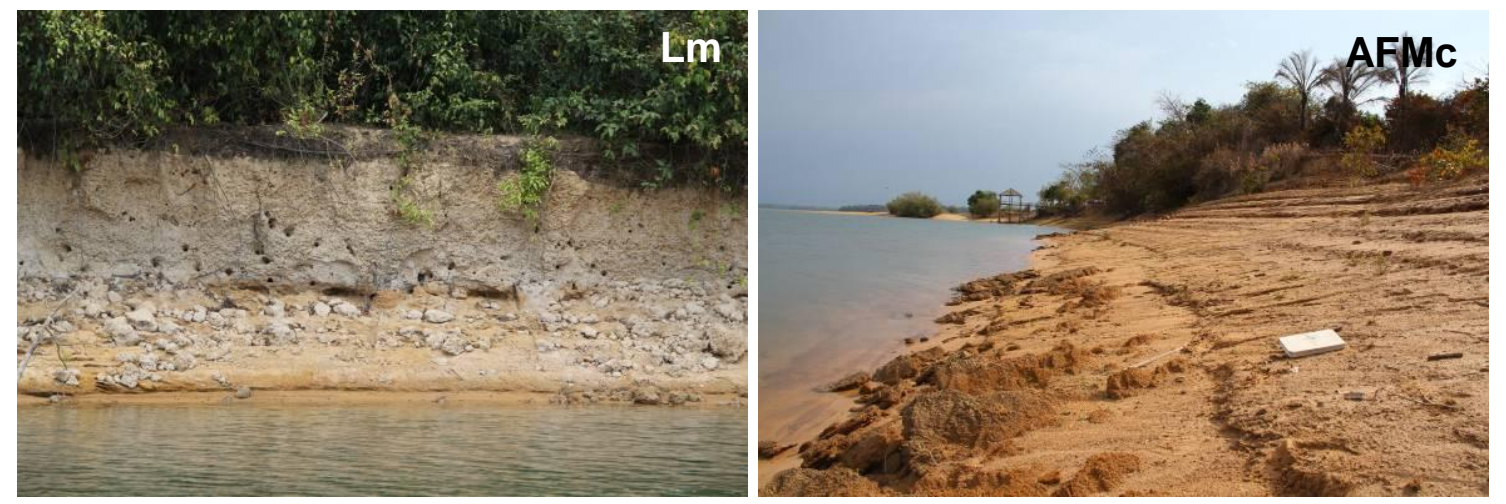

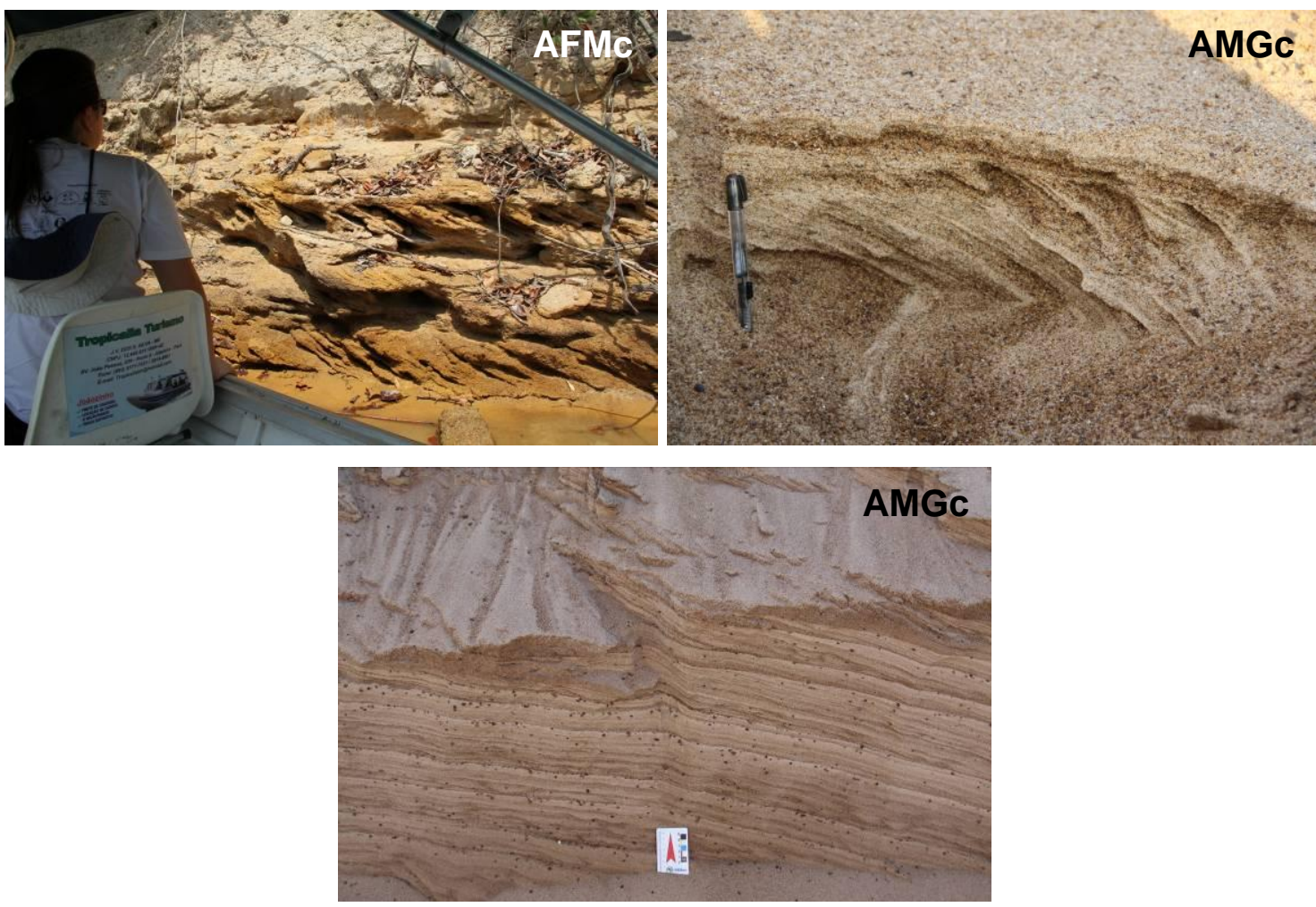

Figura 21. Fácies sedimentares reconhecidas em depósitos do rio Xingu. Lm: lamito maciço; AFMc: areia fina a média com estratificação cruzada; AMGc: areia média a grossa com grânulos e estratificação cruzda.

\subsection{Granulometria}

O total de 54 amostras da área de estudo foram analisadas ao granulômetro a laser. Os resultados obtidos são apresentados na Tabela 1.

\begin{tabular}{|c|c|c|c|c|c|c|c|c|c|c|}
\hline \multirow{3}{*}{ Amostra } & \multicolumn{10}{|c|}{ Faixa Granulométrica (\%) } \\
\hline & \multicolumn{5}{|c|}{ Areia } & \multicolumn{4}{|c|}{ Silte } & \\
\hline & $\begin{array}{l}\text { Muito } \\
\text { Grossa }\end{array}$ & Grossa & Média & Fina & $\begin{array}{c}\text { Muito } \\
\text { Fina }\end{array}$ & Grosso & Médio & Fino & $\begin{array}{c}\text { Muito } \\
\text { Fino }\end{array}$ & Argila \\
\hline
\end{tabular}

Setor 7

\begin{tabular}{|c|c|c|c|c|c|c|c|c|c|c|}
\hline XNG - 22 & 0.000 & 0.293 & 29.925 & 52.804 & 14.801 & 0.008 & 0.836 & 0.479 & 0.332 & 0.521 \\
\hline XNG - 23 & 1.040 & 17.992 & 75.391 & 5.577 & 0.000 & 0.000 & 0.000 & 0.000 & 0.000 & 0.000 \\
\hline XNG - 24 & 9.546 & 28.303 & 57.307 & 4.318 & 0.000 & 0.000 & 0.000 & 0.000 & 0.000 & 0.000 \\
\hline XNG - 25 & 21.240 & 28.942 & 34.244 & 1.284 & 0.000 & 0.000 & 0.000 & 0.000 & 0.000 & 0.000 \\
\hline XNG-35 & 14.030 & 30.456 & 49.866 & 2.727 & 0.000 & 0.000 & 0.000 & 0.000 & 0.000 & 0.000 \\
\hline XNG-34 & 21.289 & 30.961 & 37.416 & 1.358 & 0.000 & 0.000 & 0.000 & 0.000 & 0.000 & 0.000 \\
\hline
\end{tabular}

Setor 6

\begin{tabular}{|c|c|c|c|c|c|c|c|c|c|c|}
\hline XNG - 27 & 8.934 & 25.549 & 57.899 & 6.235 & 0.000 & 0.000 & 0.000 & 0.000 & 0.000 & 0.000 \\
\hline XNG - 26 & 0.000 & 2.661 & 50.088 & 43.280 & 2.608 & 0.836 & 0.528 & 0.000 & 0.000 & 0.000 \\
\hline XNG - 29 & 0.000 & 0.063 & 30.080 & 49.018 & 12.053 & 2.297 & 2.759 & 1.222 & 1.037 & 1.472 \\
\hline XNG - 30 & 0.000 & 5.921 & 64.015 & 29.998 & 0.065 & 0.000 & 0.000 & 0.000 & 0.000 & 0.000 \\
\hline
\end{tabular}




\begin{tabular}{|c|c|c|c|c|c|c|c|c|c|c|}
\hline \multirow{3}{*}{ Amostra } & \multicolumn{10}{|c|}{ Faixa Granulométrica (\%) } \\
\hline & \multicolumn{5}{|c|}{ Areia } & \multicolumn{4}{|c|}{ Silte } & \multirow[b]{2}{*}{ Argila } \\
\hline & $\begin{array}{l}\text { Muito } \\
\text { Grossa }\end{array}$ & Grossa & Média & Fina & \begin{tabular}{|c|} 
Muito \\
Fina
\end{tabular} & Grosso & Médio & Fino & $\begin{array}{c}\text { Muito } \\
\text { Fino }\end{array}$ & \\
\hline \multicolumn{11}{|c|}{ Setor 5} \\
\hline XNG - 31 & 0.000 & 5.530 & 76.449 & 18.021 & 0.000 & 0.000 & 0.000 & 0.000 & 0.000 & 0.000 \\
\hline XNG-33 & 3.230 & 23.496 & 69.032 & 4.243 & 0.000 & 0.000 & 0.000 & 0.000 & 0.000 & 0.000 \\
\hline XNG - 32 & 0.000 & 8.267 & 67.336 & 24.398 & 0.000 & 0.000 & 0.000 & 0.000 & 0.000 & 0.000 \\
\hline XNG-36 & 7.366 & 25.775 & 60.016 & 6.768 & 0.000 & 0.000 & 0.000 & 0.000 & 0.000 & 0.000 \\
\hline XNG-39 & 0.635 & 5.322 & 36.666 & 40.783 & 9.470 & 1.276 & 1.780 & 1.312 & 0.000 & 0.000 \\
\hline XNG-40/2 & 0.628 & 12.566 & 63.601 & 23.174 & 0.031 & 0.000 & 0.000 & 0.000 & 0.000 & 0.000 \\
\hline XNG-41 & 2.517 & 20.472 & 70.986 & 6.025 & 0.000 & 0.000 & 0.000 & 0.000 & 0.000 & 0.000 \\
\hline XNG-42 & 19.034 & 37.822 & 39.292 & 0.319 & 0.000 & 0.000 & 0.000 & 0.000 & 0.000 & 0.000 \\
\hline XNG-12 & 0.000 & 0.000 & 3.512 & 25.195 & 24.175 & 8.194 & 10.753 & 9.794 & 0.000 & 0.000 \\
\hline XNG - 13 & 12.070 & 29.830 & 52.960 & 3.278 & 0.000 & 0.000 & 0.000 & 0.000 & 0.000 & 0.000 \\
\hline XNG-43 & 5.015 & 29.683 & 63.369 & 1.933 & 0.000 & 0.000 & 0.000 & 0.000 & 0.000 & 0.000 \\
\hline XNG - 11 & 2.154 & 6.867 & 36.324 & 40.051 & 8.972 & 0.311 & \begin{tabular}{|l|}
1.388 \\
\end{tabular} & 1.100 & 1.121 & 1.315 \\
\hline$X N G-11 b$ & 1.273 & 10.200 & 50.238 & 19.750 & 0.108 & 1.658 & 2.450 & 2.807 & 2.181 & 9.335 \\
\hline XNG - 09 & 10.559 & 22.492 & 50.146 & 14.768 & 0.719 & 0.590 & 0.000 & 0.000 & 0.000 & 0.000 \\
\hline $\mathrm{XNG}-14$ & 0.000 & 5.473 & 74.982 & 19.545 & 0.000 & 0.000 & 0.000 & 0.000 & 0.000 & 0.000 \\
\hline$X N G-06 b$ & 0.000 & 0.006 & 39.860 & 59.808 & 0.325 & 0.000 & 0.000 & 0.000 & 0.000 & 0.000 \\
\hline XNG - 15 & 18.770 & 37.485 & 39.093 & 0.291 & 0.000 & 0.000 & 0.000 & 0.000 & 0.000 & 0.000 \\
\hline XNG-16-FDP-T & 0.000 & 0.043 & 0.718 & \begin{tabular}{|l|}
0.405 \\
\end{tabular} & 3.388 & 11.155 & 22.612 & 18.926 & 0.000 & 0.000 \\
\hline $\mathrm{XNG}-18$ & 29.331 & 28.717 & 16.851 & 0.005 & 0.000 & 0.000 & 0.000 & 0.000 & 0.000 & 0.000 \\
\hline XNG - 20 & 22.215 & 25.168 & 29.193 & 1.910 & 0.000 & 0.000 & 0.000 & 0.000 & 0.000 & 0.000 \\
\hline XNG - 21 & 1.366 & 19.223 & 74.271 & \begin{tabular}{|l|}
5.141 \\
\end{tabular} & 0.000 & 0.000 & 0.000 & 0.000 & 0.000 & 0.000 \\
\hline XNG-45-A & 16.002 & 21.476 & 36.017 & 10.080 & 1.785 & 1.472 & \begin{tabular}{|l|}
0.723 \\
\end{tabular} & 0.721 & 0.000 & 0.000 \\
\hline XNG-45-B & 19.985 & 22.818 & 30.678 & 4.567 & 0.483 & 0.684 & 0.569 & 0.721 & 0.000 & 0.000 \\
\hline XNG-60 & 3.598 & 16.082 & 64.316 & 15.749 & 0.000 & 0.000 & 0.000 & 0.000 & 0.000 & 0.000 \\
\hline XNG-46-A & 0.000 & 0.025 & 21.543 & 42.451 & 16.975 & 2.232 & 3.390 & 4.553 & 0.000 & 0.000 \\
\hline XNG-47-PRAIA & 25.791 & 34.360 & 28.533 & 0.189 & 0.000 & 0.000 & 0.000 & 0.000 & 0.000 & 0.000 \\
\hline XNG-59 & 0.000 & 0.000 & 19.320 & 61.753 & 17.453 & 0.013 & 1.111 & 0.350 & 0.000 & 0.000 \\
\hline XNG-58 & 0.083 & 10.434 & 83.288 & 6.195 & 0.000 & 0.000 & 0.000 & 0.000 & 0.000 & 0.000 \\
\hline XNG-57 & 0.000 & 4.814 & 71.642 & 23.543 & 0.000 & 0.000 & 0.000 & 0.000 & 0.000 & 0.000 \\
\hline XNG-56 & 4.050 & 20.372 & 55.688 & 13.708 & 2.543 & 1.760 & 0.242 & 0.798 & 0.000 & 0.000 \\
\hline XNG-51-B & 0.000 & 0.717 & 4.139 & 4.258 & 15.024 & 25.024 & 17.802 & 12.078 & 0.000 & 0.000 \\
\hline XNG-54 & 1.752 & 17.515 & \begin{tabular}{|l|}
71.172 \\
\end{tabular} & 9.561 & 0.000 & 0.000 & 0.000 & 0.000 & 0.000 & 0.000 \\
\hline XNG-55 & 0.131 & 3.152 & 27.154 & 42.390 & 19.814 & 2.144 & 1.741 & 1.289 & 0.000 & 0.000 \\
\hline XNG-48 & 7.541 & 25.548 & 57.577 & 5.736 & 0.738 & 1.744 & 0.353 & 0.530 & 0.000 & 0.000 \\
\hline \multicolumn{11}{|c|}{ Setor 3} \\
\hline XNG-65-T & 0.000 & 0.000 & 9.874 & 58.933 & 21.439 & 0.128 & 2.257 & 1.685 & 0.000 & 0.000 \\
\hline XNG-64 & 0.000 & 0.037 & 0.068 & 0.403 & 1.031 & 6.420 & 18.150 & 22.995 & 0.000 & 0.000 \\
\hline XNG-73 & 4.125 & 15.150 & 58.729 & 21.611 & 0.029 & 0.000 & 0.000 & 0.000 & 0.000 & 0.000 \\
\hline XNG-68 & 0.000 & 7.257 & 62.180 & 30.389 & 0.174 & 0.000 & 0.000 & 0.000 & 0.000 & 0.000 \\
\hline XNG-72A & 16.139 & 21.068 & 36.863 & 11.800 & 0.183 & 0.356 & 0.031 & 0.000 & 0.000 & 0.000 \\
\hline
\end{tabular}




\begin{tabular}{|c|c|c|c|c|c|c|c|c|c|c|}
\hline \multirow{3}{*}{ Amostra } & \multicolumn{10}{|c|}{ Faixa Granulométrica (\%) } \\
\hline & \multicolumn{5}{|c|}{ Areia } & \multicolumn{4}{|c|}{ Silte } & \multirow[b]{2}{*}{ Argila } \\
\hline & $\begin{array}{c}\text { Muito } \\
\text { Grossa }\end{array}$ & Grossa & Média & Fina & $\begin{array}{c}\text { Muito } \\
\text { Fina } \\
\end{array}$ & Grosso & Médio & Fino & $\begin{array}{c}\text { Muito } \\
\text { Fino }\end{array}$ & \\
\hline XNG-72B & 6.435 & 13.245 & 40.693 & 28.715 & 5.244 & 0.657 & 1.080 & 0.759 & 0.000 & 0.000 \\
\hline XNG-72C & 7.977 & 14.932 & 46.349 & 23.613 & 0.453 & 0.524 & 0.590 & 0.381 & 0.000 & 0.000 \\
\hline \multicolumn{11}{|c|}{ Setor 2} \\
\hline XNG-71 & 3.346 & 18.470 & 61.016 & 12.819 & 0.040 & 1.341 & 0.703 & 0.849 & 0.000 & 0.000 \\
\hline XNG-70 & 25.018 & 35.752 & 28.899 & 0.045 & 0.000 & 0.000 & 0.000 & 0.000 & 0.000 & 0.000 \\
\hline XNG-69 & 6.020 & 16.895 & 52.935 & 20.533 & 0.207 & 0.648 & 0.265 & 0.438 & 0.000 & 0.000 \\
\hline
\end{tabular}

Tabela 1. Distribuição granulométrica das amostras estudadas. Dados em porcentagem em massa por fração granulométrica.

Boxplots do diâmetro médio da fração areia das amostras agrupadas segundo os setores geomorfológicos do rio Xingu estão representados na Figura 22.

Areias do setor 7, correspondentes ao baixo curso do rio Iriri, apresentam granulação mais grossa que os sedimentos dos demais setores. A granulação mais grossa das areias do rio Iriri é ressaltada se comparada às areias mais finas do setor 6 , correspondentes ao rio Xingu a montante do rio Iriri.

O setor 5 , com maior área de barras, o que define o seu caráter deposicional, apresenta sedimentos com maior variação granulométrica. Neste setor, as areias apresentam bimodalidade, variando de areia muito grossa a grossa e areia muito fina a fina. Em campo, foram identificados múltiplos canais com características fisiográficas e hidrológicas distintas, o que gera padrões deposicionais com diferentes fácies sedimentares. A análise granulométrica também indica oscilação do tamanho médio dos grãos ao longo do curso do rio. Esta oscilação é observada na Figura 23.

O setor 4, de caráter erosivo, não dispõe de amostras devido à dificuldade de acesso.

O setor 3 apresenta sedimentos com menor variação granulométrica em relação ao setor 5 . Nota-se que este setor está isolado dos demais setores por barreiras naturais, como a grande densidade de barras ao final do setor 5 e pelo canal afogado do setor 2 .

O setor 2 tem areias de granulação média a grossa e menor variação granulométrica em relação aos demais setores. Observar que dentre os demais 
setores, este apresenta menor densidade de barras e as amostras analisadas estão localizadas em zona restrita do final do setor.

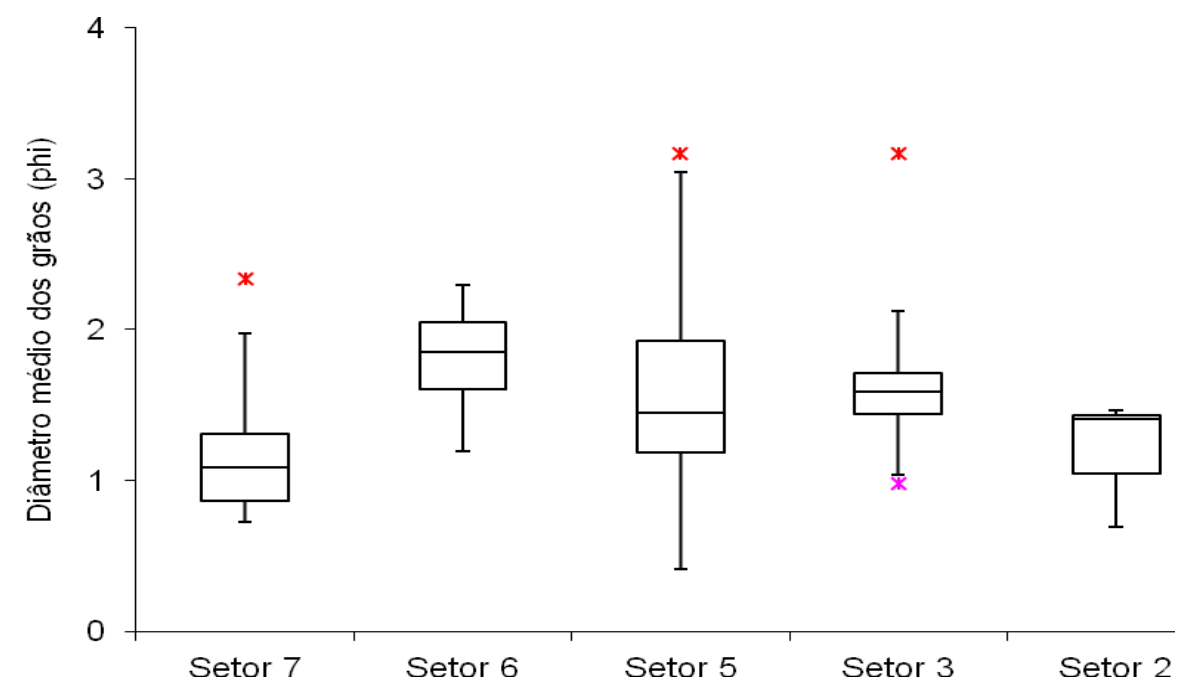

Figura 22. Variação do diâmetro médio (unidade phi) das amostras de areia dos setores geomorfógicos 2 a 7 . Setor $7(n=6)$, setor $6(n=4)$, setor $5(n=34)$, setor $3(n=6)$, setor $2(n=3)$. Areia grossa (0-1 phi), areia média (1-2 phi), areia fina (2-3 phi), areia muito fina (3-4 phi).

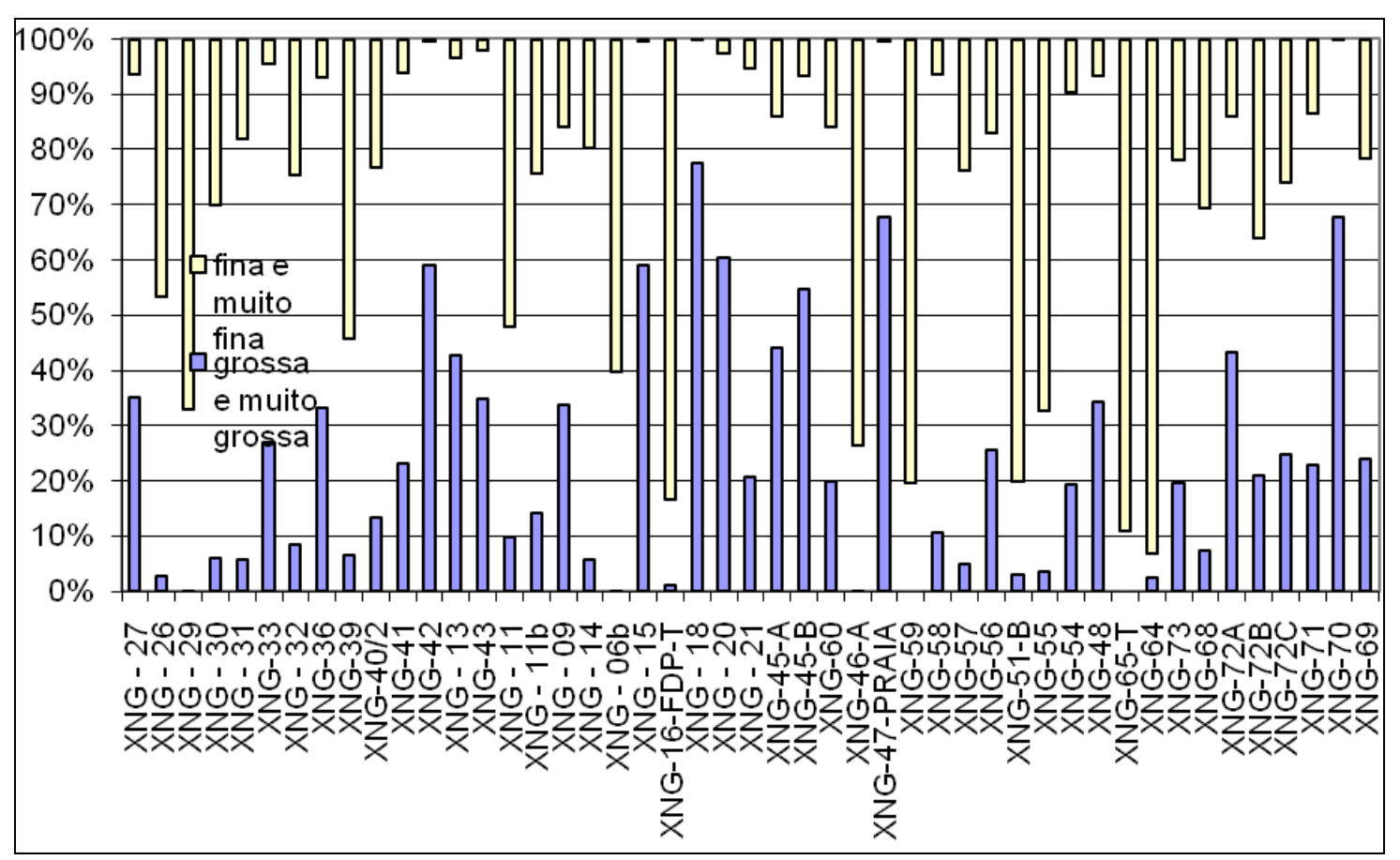

Figura 23. Variação das porcentagens de areia muito fina a fina e muito grossa a grossa. Nota-se oscilação na granulação média das amostras dos setores 6 , 5 e 3 e 2. 


\subsection{Minerais Pesados}

Foi realizada a identificação e contagem dos minerais pesados em lâminas de grãos. A Tabela 2 apresenta a assembleia de minerais pesados das amostras analisadas.

\begin{tabular}{|c|c|c|c|c|c|c|c|c|c|c|c|c|}
\hline \multicolumn{2}{|c|}{ Porcentagem } & $\mathrm{HBL}$ & PIX & GRA & AND & SIL & EST & EPI & TUR & ZIR & LIM & OPA \\
\hline \multirow{7}{*}{ 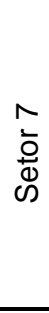 } & XNG-22 & 4.4 & 0.0 & 5.9 & 0.0 & 1.5 & 10.3 & 20.6 & 0.0 & 48.5 & 7.4 & 87.4 \\
\hline & XNG-23 & 16.1 & 8.1 & 50.0 & 6.5 & 8.1 & 3.2 & 8.1 & 0.0 & 0.0 & 0.0 & 51.6 \\
\hline & XNG-24 & 25.0 & 0.9 & 31.9 & 0.9 & 8.6 & 1.7 & 9.5 & 0.0 & 0.0 & 11.2 & 40.7 \\
\hline & XNG-25 & 9.1 & 0.8 & 56.8 & 4.5 & 6.8 & 3.0 & 0.8 & 0.0 & 0.8 & 15.9 & 51.2 \\
\hline & XNG-35 & 7.9 & 3.0 & 69.1 & 1.8 & 4.2 & 1.8 & 4.8 & 0.6 & 0.6 & 3.6 & 61.5 \\
\hline & XNG-34 & 29.3 & 0.0 & 19.5 & 9.8 & 12.2 & 0.0 & 2.4 & 0.0 & 0.0 & 24.4 & 60.9 \\
\hline & média & 15.3 & 2.1 & 38.9 & 3.9 & 6.9 & 3.3 & 7.7 & 0.1 & 8.3 & 10.4 & 58.9 \\
\hline \multirow{5}{*}{$\begin{array}{l}0 \\
\overline{0} \\
\stackrel{0}{0} \\
\omega\end{array}$} & XNG-27 & 2.9 & 11.4 & 11.4 & 0.0 & 0.0 & 31.4 & 20.0 & 11.4 & 0.0 & 11.4 & 78.0 \\
\hline & XNG-26 & 9.4 & 6.6 & 7.5 & 1.9 & 2.8 & 6.6 & 7.5 & 14.2 & 24.5 & 10.4 & 58.1 \\
\hline & XNG-29 & 42.3 & 3.1 & 1.0 & 2.1 & 2.1 & 7.2 & 15.5 & 10.3 & 2.1 & 10.3 & 27.7 \\
\hline & XNG-30 & 12.0 & 2.0 & 5.0 & 1.0 & 5.0 & 14.0 & 26.0 & 18.0 & 10.0 & 5.0 & 54.3 \\
\hline & média & 16.6 & 5.8 & 6.3 & 1.2 & 2.5 & 14.8 & 17.3 & 13.5 & 9.1 & 9.3 & 54.5 \\
\hline \multirow{31}{*}{ 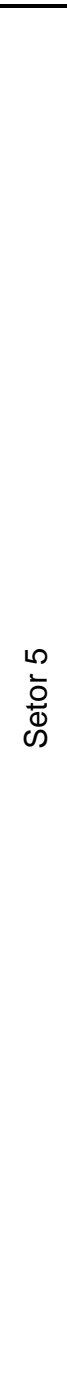 } & XNG-31 & 15.6 & 12.5 & 3.1 & 3.1 & 3.1 & 18.8 & 15.6 & 6.3 & 0.0 & 12.5 & 52.5 \\
\hline & XNG-33 & 31.0 & 7.1 & 26.2 & 4.8 & 7.1 & 0.0 & 9.5 & 0.0 & 0.0 & 11.9 & 47.6 \\
\hline & XNG-32 & 12.8 & 0.0 & 14.9 & 0.0 & 6.4 & 12.8 & 12.8 & 14.9 & 2.1 & 17.0 & 43.4 \\
\hline & XNG-36 & 12.0 & 4.8 & 1.2 & 3.6 & 4.8 & 24.1 & 8.4 & 18.1 & 0.0 & 18.1 & 60.2 \\
\hline & XNG-39 & 16.8 & 2.0 & 5.9 & 0.0 & 1.0 & 10.9 & 12.9 & 16.8 & 18.8 & 7.9 & 48.8 \\
\hline & XNG-40 & 23.7 & 3.4 & 5.1 & 3.4 & 5.1 & 11.9 & 22.0 & 13.6 & 1.7 & 8.5 & 30.8 \\
\hline & XNG-41 & 26.5 & 0.0 & 6.1 & 4.1 & 4.1 & 8.2 & 14.3 & 12.2 & 2.0 & 8.2 & 60.0 \\
\hline & XNG-42 & 24.2 & 0.0 & 16.7 & 0.0 & 1.5 & 33.3 & 9.1 & 4.5 & 1.5 & 1.5 & 69.9 \\
\hline & XNG-12 & 64.9 & 0.7 & 0.0 & 1.3 & 9.9 & 6.0 & 4.6 & 5.3 & 2.0 & 3.3 & 27.0 \\
\hline & XNG-13 & 8.8 & 2.9 & 0.0 & 2.9 & 8.8 & 11.8 & 23.5 & 23.5 & 0.0 & 14.7 & 59.2 \\
\hline & XNG-43 & 10.5 & 7.9 & 2.6 & 2.6 & 0.0 & 18.4 & 10.5 & 18.4 & 5.3 & 5.3 & 72.3 \\
\hline & XNG-11 & 4.9 & 1.1 & 2.7 & 0.0 & 4.3 & 12.4 & 24.3 & 7.0 & 27.0 & 1.1 & 61.2 \\
\hline & XNG-09 & 19.3 & 0.9 & 5.3 & 1.8 & 3.5 & 15.8 & 22.8 & 17.5 & 3.5 & 6.1 & 60.1 \\
\hline & XNG-14 & 24.0 & 2.4 & 11.2 & 1.6 & 1.6 & 17.6 & 18.4 & 10.4 & 6.4 & 4.0 & 61.5 \\
\hline & XNG-06-B & 36.9 & 7.2 & 6.3 & 0.9 & 2.7 & 9.9 & 17.1 & 9.0 & 3.6 & 3.6 & 51.4 \\
\hline & XNG-15 & 18.5 & 0.0 & 3.1 & 3.1 & 1.5 & 15.4 & 18.5 & 23.1 & 0.0 & 10.8 & 56.3 \\
\hline & XNG-18 & 0.0 & 0.0 & 0.0 & 0.0 & 5.0 & 0.0 & 0.0 & 5.0 & 5.0 & 85.0 & 67.9 \\
\hline & XNG-20 & 14.5 & 1.8 & 9.1 & 7.3 & 3.6 & 12.7 & 29.1 & 12.7 & 1.8 & 7.3 & 64.2 \\
\hline & XNG-21 & 18.8 & 4.2 & 4.2 & 10.4 & 4.2 & 12.5 & 16.7 & 10.4 & 0.0 & 12.5 & 56.9 \\
\hline & XNG-45-A & 22.5 & 7.5 & 5.0 & 0.0 & 5.0 & 5.0 & 2.5 & 12.5 & 0.0 & 40.0 & 68.9 \\
\hline & XNG-45-B & 3.0 & 9.1 & 9.1 & 0.0 & 0.0 & 15.2 & 30.3 & 6.1 & 0.0 & 24.2 & 73.1 \\
\hline & XNG-60 & 18.6 & 5.1 & 3.4 & 0.0 & 1.7 & 11.9 & 16.9 & 22.0 & 1.7 & 11.9 & 55.2 \\
\hline & XNG-47 & 10.9 & 12.7 & 20.0 & 5.5 & 1.8 & 14.5 & 7.3 & 20.0 & 0.0 & 7.3 & 61.9 \\
\hline & XNG-59 & 12.6 & 6.3 & 2.6 & 0.5 & 1.0 & 8.9 & 12.0 & 6.8 & 31.9 & 4.2 & 49.7 \\
\hline & XNG-58 & 5.0 & 0.8 & 4.1 & 1.7 & 0.8 & 28.1 & 19.8 & 33.9 & 0.8 & 1.7 & 63.4 \\
\hline & XNG-56 & 19.4 & 0.0 & 6.0 & 1.5 & 3.0 & 9.0 & 10.4 & 22.4 & 1.5 & 13.4 & 57.8 \\
\hline & XNG-49 & 2.0 & 2.0 & 4.0 & 0.0 & 13.1 & 12.1 & 32.3 & 14.1 & 9.1 & 7.1 & 64.4 \\
\hline & XNG-55 & 37.5 & 1.4 & 1.4 & 1.9 & 3.2 & 8.3 & 6.9 & 4.6 & 7.4 & 21.3 & 44.1 \\
\hline & XNG-54 & 33.7 & 0.0 & 3.3 & 3.3 & 1.1 & 6.5 & 19.6 & 16.3 & 1.1 & 6.5 & 44.0 \\
\hline & XNG-48 & 16.7 & 3.3 & 10.0 & 3.3 & 0.0 & 23.3 & 6.7 & 6.7 & 13.3 & 3.3 & 73.6 \\
\hline & média & 18.9 & 3.6 & 6.4 & 2.3 & 3.6 & 13.2 & 15.2 & 13.1 & 4.9 & 12.7 & 56.9 \\
\hline
\end{tabular}




\begin{tabular}{|c|c|c|c|c|c|c|c|c|c|c|c|c|}
\hline \multicolumn{2}{|c|}{ Porcentagem } & $\mathrm{HBL}$ & PIX & GRA & AND & SIL & EST & EPI & TUR & ZIR & LIM & OPA \\
\hline \multirow{7}{*}{$\begin{array}{l}\text { O } \\
\overline{0} \\
\text { D } \\
\text { c) }\end{array}$} & XNG-65-T & 70.8 & 13.2 & 0.0 & 0.9 & 2.8 & 0.0 & 4.7 & 0.0 & 0.0 & 4.7 & 10.0 \\
\hline & XNG-72-A & 34.7 & 10.2 & 4.1 & 4.1 & 2.0 & 6.1 & 16.3 & 6.1 & 0.0 & 12.2 & 57.9 \\
\hline & XNG-72-B & 25.4 & 5.1 & 3.4 & 1.7 & 2.5 & 7.6 & 7.6 & 7.6 & 29.7 & 5.9 & 47.8 \\
\hline & XNG-72-C & 24.1 & 7.2 & 2.4 & 2.4 & 4.8 & 8.4 & 15.7 & 15.7 & 7.2 & 10.8 & 56.3 \\
\hline & XNG-68 & 17.2 & 5.4 & 8.6 & 0.0 & 2.2 & 7.5 & 21.5 & 20.4 & 4.3 & 6.5 & 36.2 \\
\hline & XNG-62/2 & 48.9 & 8.6 & 2.3 & 3.4 & 2.3 & 8.6 & 8.6 & 1.1 & 9.8 & 1.7 & 33.4 \\
\hline & média & 36.8 & 8.3 & 3.5 & 2.1 & 2.8 & 6.4 & 12.4 & 8.5 & 8.5 & 7.0 & 40.3 \\
\hline \multirow{5}{*}{$\begin{array}{l}N \\
\overline{0} \\
\stackrel{0}{0} \\
\text { ஸे }\end{array}$} & XNG-71 & 0.0 & 0.0 & 0.0 & 13.5 & 5.4 & 10.8 & 0.0 & 37.8 & 10.8 & 5.4 & 83.3 \\
\hline & XNG-70 & 0.0 & 0.0 & 0.0 & 28.6 & 0.0 & 14.3 & 0.0 & 14.3 & 14.3 & 14.3 & 96.7 \\
\hline & XNG-69 & 0.0 & 0.0 & 0.0 & 5.4 & 0.0 & 10.8 & 0.0 & 16.2 & 48.6 & 5.4 & 89.9 \\
\hline & XNG-69-B & 0.0 & 0.0 & 0.0 & 4.8 & 9.5 & 14.3 & 4.8 & 42.9 & 14.3 & 4.8 & 87.3 \\
\hline & média & 0.0 & 0.0 & 0.0 & 13.1 & 3.7 & 12.5 & 1.2 & 27.8 & 22.0 & 7.5 & 89.3 \\
\hline
\end{tabular}

Tabela 2. Assembleia de minerais pesados transparentes não-micáceos que contabilizaram acima de cinco por cento dos grãos. Amostras na ordem do curso do rio Xingu e Iriri, acompanhadas das médias por setor. Hornblenda $(\mathrm{HBL})$, piroxênio (PIX), granada (GRA), andaluzita (AND), sillimanita (SIL), estaurolita (EST), epidoto (EPI), turmalina (TUR), zircão (ZIR), limonita (LIM), opacos (OPA).

Para 0 setor 7, correspondente ao rio Iriri, a assembleia de minerais pesados apresenta maiores porcentagens $(>8 \%)$ de hornblenda, granada, zircão e limonita. Para o setor 6 , correspondente ao rio Xingu a montante do Iriri, a assembleia de minerais pesados foi mais diversificada, com maiores porcentagens $(>8 \%)$ de hornblenda, estaurolita, epidoto, turmalina, zircão e limonita. Nota-se grande diferença na porcentagem de granada entre este dois setores, além da maior porcentagem de piroxênio, estaurolita, epidoto e turmalina no rio Xingu.

Para o setor 5 , a assembleia de minerais pesados apresenta maiores porcentagens $(>8 \%)$ de hornblenda, estaurolita, epidoto, turmalina e limonita. Esta assembleia se assemelha à porcentagem de minerais pesados do rio Xingu a montante do rio Iriri. Apenas algumas amostras (XNG 33, XNG 42, XNG 47 e XNG 48) apresentam porcentagens de granada que aproximam à do rio Iriri.

O setor 3 apresenta assembleia de minerais pesados com porcentagens maiores $(>8 \%)$ de hornblenda, piroxênio, epidoto, turmalina e zircão. Esta assembleia também se assemelha à do rio Xingu a montante do rio Iriri, com porcentagem baixa de granada e maior de epidoto e turmalina. 
O setor 2 apresenta assembleia de minerais pesados mais diferenciada dos demais setores, com maiores porcentagens ( $>8 \%$ ) de andaluzita, estaurolita, turmalina e zircão. Nota-se a ausência de hornblenda, piroxênio e granada e maior fração de andaluzita em relação aos outros setores, além do aumento na porcentagem de minerais opacos.

\subsection{Sensibilidade TL e LOE}

\subsubsection{Sensibilidade TL}

Os diagramas boxplot da Figura 24 apresentam a variabilidade da sensibilidade TL das amostras dos diferentes setores geomorfológicos dos rios Xingu e Iriri.

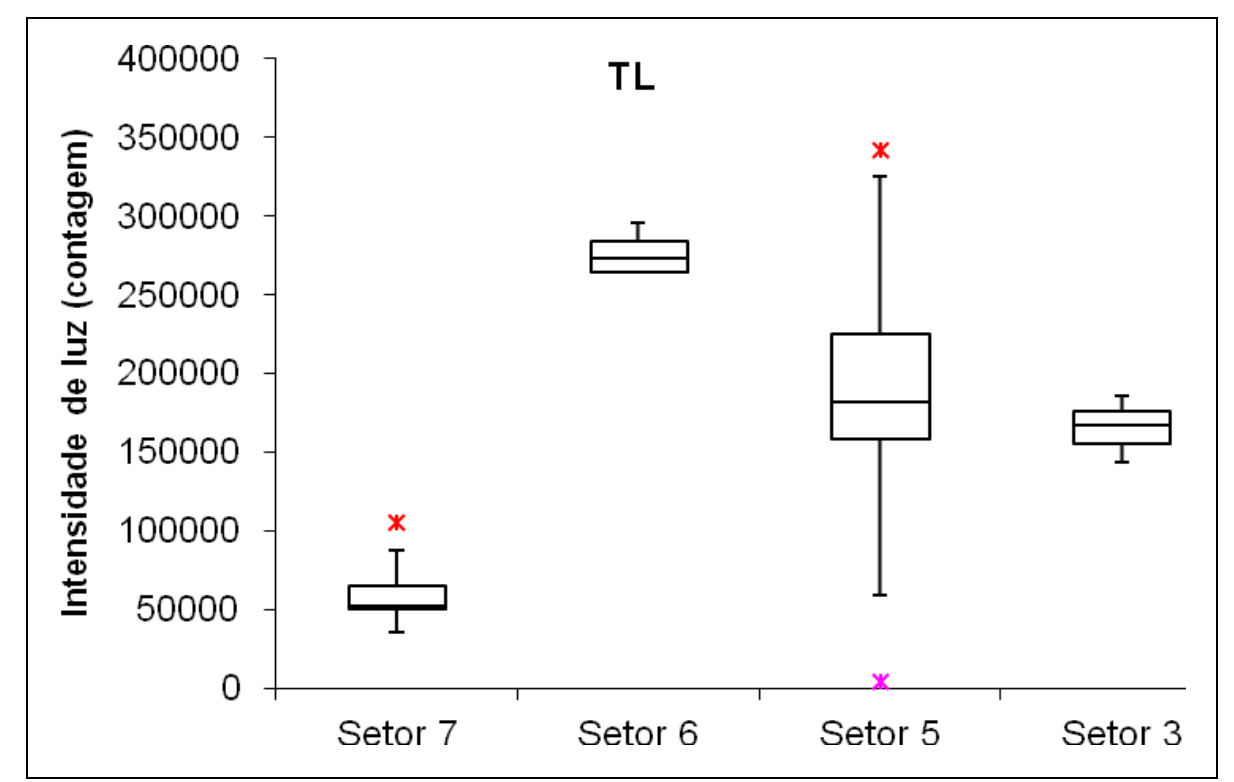

Figura 24. Gráficos boxplot da sensibilidade TL de grãos de quartzo e feldspato indicam diferenças significativas entre os setores geomorfológicos do rios Xingu e Iriri. Setor $7(n=5)$, setor $6(n=4)$, setor $5(n=28)$ e setor $3(n=3)$. A sensibilidade de cada amostra é representada por medidas em 12 alíquotas de grãos.

As areias do rio Iriri (setor 7) apresentam sinal TL mais baixo, com menor variação entre amostras, se comparadas às areias de outros setores. 
Areias do rio Xingu à montante do rio Iriri (setor 6) têm o sinal TL mais intenso entre os setores analisados. As amostras dos setores 6 e 7 representam respectivamente as caracterísitcas de luminescência das areias dos rios Xingu e Iriri.

Areias do setor 5 , correspondentes à Volta Grande do rio Xingu, têm maior variação no sinal TL. Este setor é dominado por canais múltiplos e tem maior densidade de barras em relação aos demais setores.

As areias do setor 3 , embora tenham mediana similar à do setor 5 , apresentam baixa variação do sinal TL.

A Figura 25 apresenta os gráficos boxplot das amostras de barras ativas ordenadas de montante para jusante e agrupadas em termos dos setores geomorfológicos. Nota-se padrão oscilatório da mediana das amostras do setor 5 , o que indica variação de proveniência dentro deste setor. Esta variação é caracterizada por mudanças na proporção de sedimentos com grau de retrabalhamento mais baixo. A redução de sensibilidade indicaria maior proporção de sedimentos proximais, com grau de retrabalhamento mais baixo.

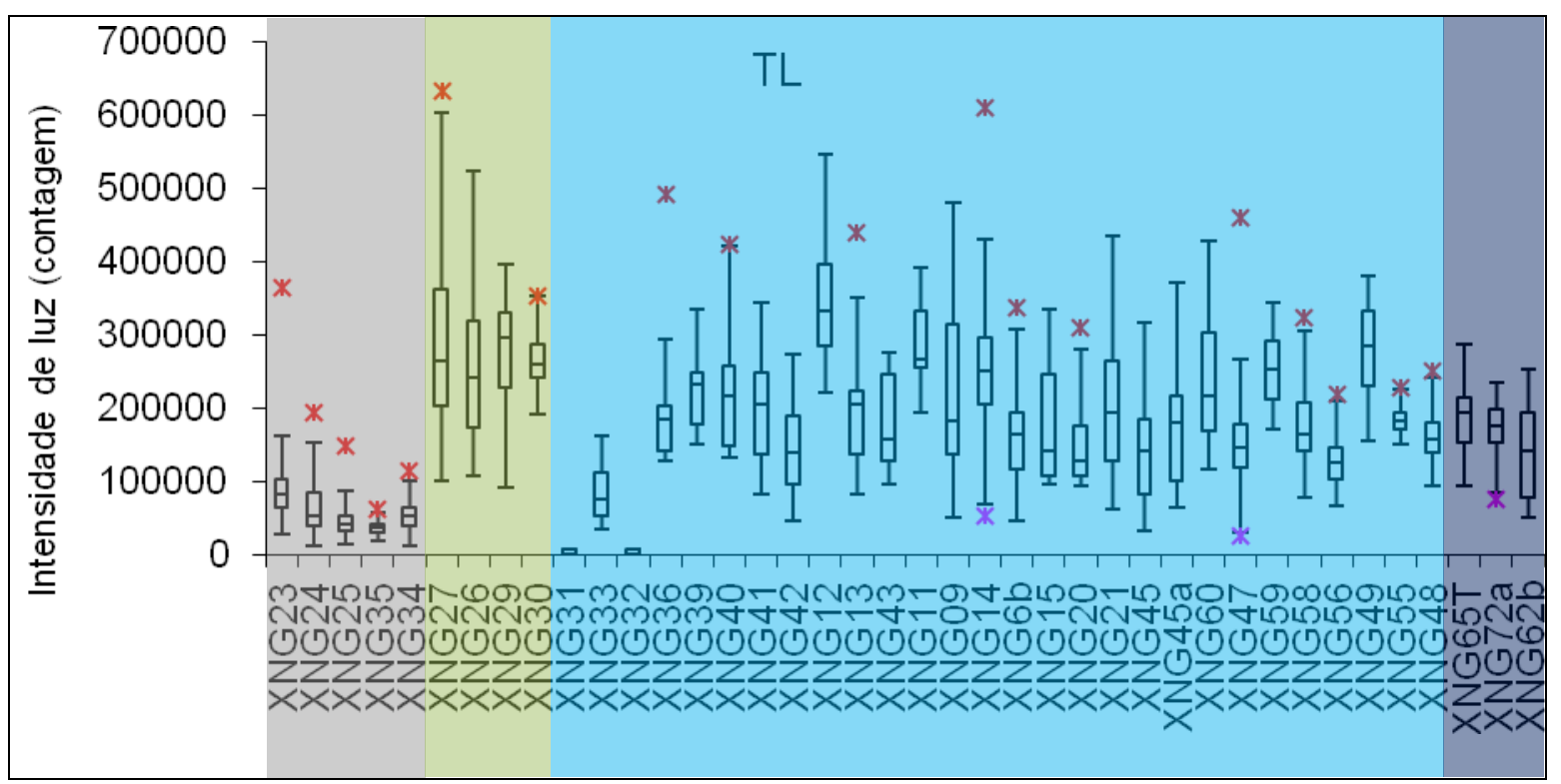

Figura 25. Gráficos boxplot do sinal TL das amostras de barras ativas, ordenadas de montante para jusante ao longo dos setores 7 (cinza), 6 (verde), 5 (azul) e 3 (roxo). Cada amostra (boxplot) contempla 12 alíquotas de grãos de areia. 


\subsubsection{Sensibilidade LOE}

O sinal IR-LOE (estímulo por luz infravermelho) é proporcional à quantidade de feldspato e não é influenciado pela luminescência do quartzo na amostra. A luminescência do quartzo é representada pelo sinal derivado de estímulo com luz azul (A-LOE). Os gráficos das figuras 26 e 27 apresentam as medidas de IR-LOE e A-LOE das amostras de fácies superficiais de cada setor geomorfológico.

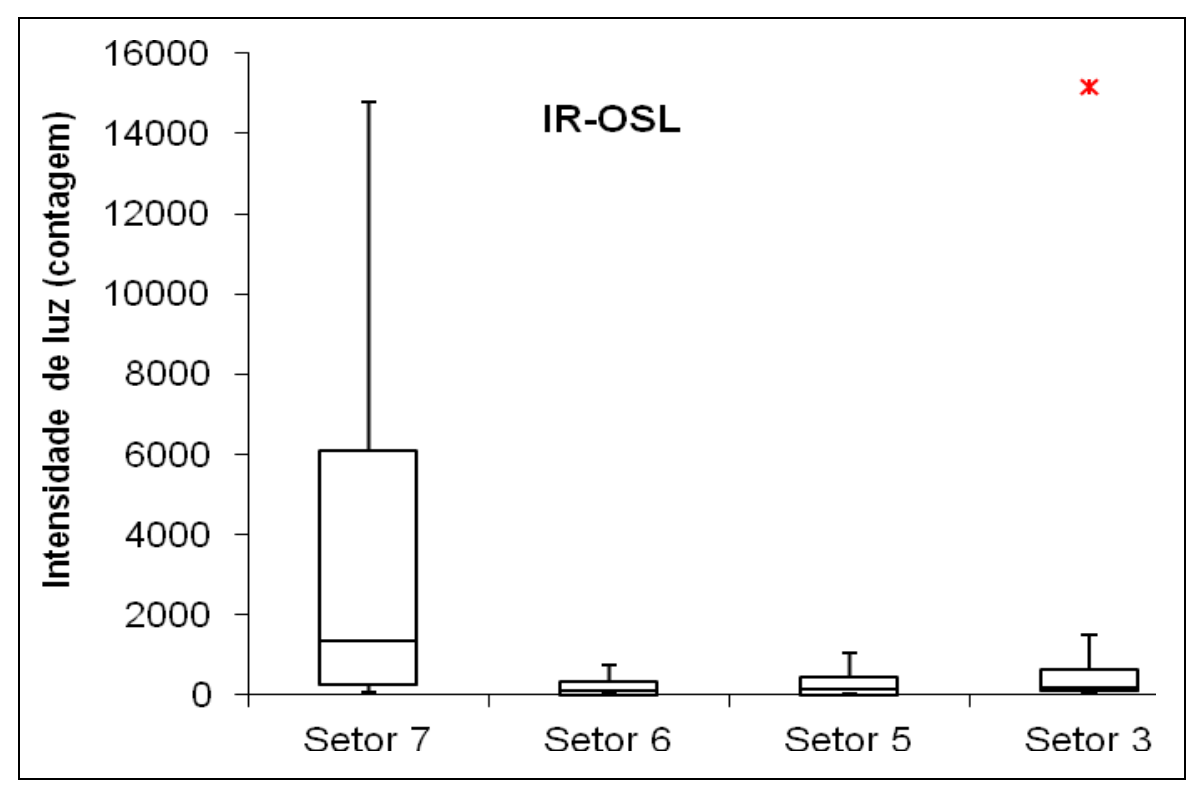

Figura 26. Gráficos boxplot do sinal de luminescência com estímulo por infravermelho. Setor $7(n=5)$, setor $6(n=4)$, setor $5(n=28)$ e setor $3(n=3)$. Cada amostra é representada pela média de 12 alíquotas. 


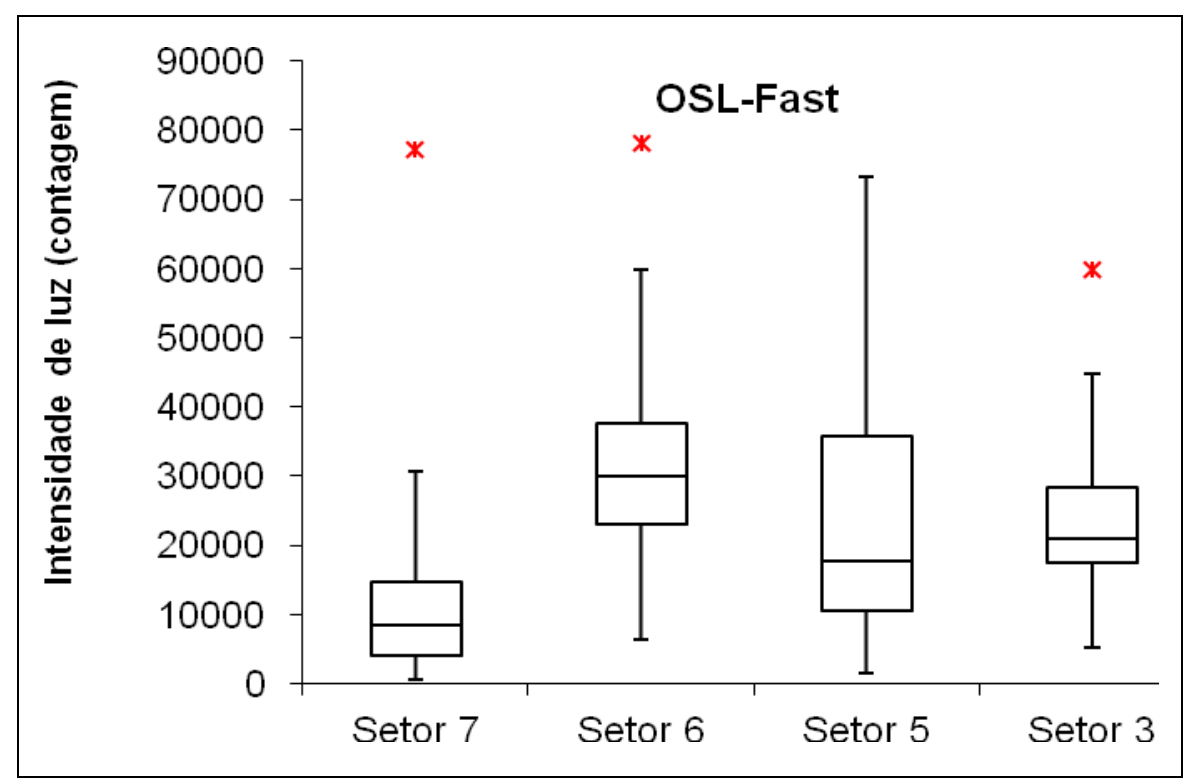

Figura 27. Gráficos boxplot do sinal de luminesciencia com estímulo com luz azul. Setor $7(n=5)$, setor $6(n=4)$, setor $5(n=28)$ e setor $3(n=3)$. Cada amostra é representada pela média de 12 alíquotas.

Os sedimentos do rio Iriri (setor 7) apresentam sensibilidade IR-LOE mais elevada e com maior variância do que os sedimentos do rio Xingu (Figura 26). Assim, nota-se que as areias do rio Iriri apresentam quantidade significativamente maior de feldspato que as areias do rio Xingu a montante (setor 6) e jusante (setores 5 e 3). Já a luminescência do quartzo (estímulo por luz azul) das areias do rio Iriri tem baixa sensibilidade se comparada aos sedimentos do rio Xingu. Isto significa que o grau de retrabalhamento das areias deste rio é menor que o dos demais setores, principalmente, se comparado ao setor 6 (rio Xingu a montante do rio Iriri), que areias do rio Xingu sem influência de areias do rio Iriri. Portanto, os dois maiores rios contribuintes para as areias da Volta Grande apresentam características deposicionais e proveniências distintas.

As areias dos setores 3, 5 e 6 têm sensibilidade LOE similares, caracterizada por baixo sinal IR-LOE e alto sinal com estímulo por luz azul. O setor 5 se diferencia pela maior variância do sinal luminescente do quartzo. Isto indica proveniência mais diversificada em relação aos demais setores. 


\section{Discussão}

\subsection{Proveniência, transporte e estocagem de sedimentos}

O rio Xingu na região da Volta Grande possui o rio Iriri como principal tributário (setor 7), o qual possui aproximadamente $1000 \mathrm{~km}$ de extensão desde nascentes no norte do Estado do Mato Grosso. O rio Xingu (setor 6) a montante do rio Iriri percorre cerca de $1700 \mathrm{~km}$ desde as suas nascentes no Planalto dos Guimarães, no centro sul do Estado do Mato Grosso. Embora os dois rios tenham curso paralelo e drenam área geologicamente parecida, há diferenças na proveniência e grau de retrabalhamento de suas areias.

A segmentação do rio Xingu em canais múltiplos pode estar relacionada à formação de depósitos de dunas subaquosas ou sistemas de fraturas. Isto pode produzir canais com profundidade e vazão distintas, o que geraria dinâmicas sedimentares diferenciadas em relação ao transporte e deposição das areias. Isto resultaria em conseqüente seleção granulométrica das areias ao longo da Volta Grande do rio Xingu.

As diferentes fácies sedimentares descritas foram observadas em todos os setores amostrados. No rio Iriri, os depósitos arenosos são predominantes com barras marginais ou associadas a afloramentos do substrato rochoso. Estas barras são ativas e permanecem submersas durante as cheias. Há maior predomínio da fácies AMGc (arenito médio a grosso com estratificações cruzadas) e análise granulométrica indica que suas areias tem baixa quantidade ou ausência de material pelítico e são mais grossas que as dos demais setores visitados.

As assembleias de minerais pesados dos setores 7 (rio Iriri) e 6 (rio Xingu a montante do Iriri) diferem entre si pela grande quantidade de granada $\mathrm{e}$ baixa quantidade de turmalina no rio Iriri. $O$ fato da granada ser mineral metaestável, susceptível à dissolução química em ambientes superficiais, sua presença em abundância nas areias do rio Iriri reflete proximidade com área fonte rica nesse mineral. As areias do rio Iriri também apresentaram maior sinal IR-LOE que areias do rio Xingu. Essa diferença indica maior quantidade de feldspato no rio Iriri, cujas areias também apresentam quartzo com sensibilidade LOE relativamente reduzida. Estas três características configuram 
a assinatura das areias do rio Iriri. Como os rios Xingu e Iriri tem longo curso paralelo $(\sim 1000 \mathrm{Km})$ e drenam áreas geologicamente parecidas. A elevada concentração de feldspato nas areias do rio Irir pode estar relacionada à áreas fontes proximais. De acordo com o mapa geológico da CPRM, há kinzingitos, rocha rica em feldspato e granada, drenados pelo rio Iriri próximo à sua foz com o rio Xingu. Isto explicaria quantidade alta de granada e feldspato nas areias do rio Iriri.

A assembleia de minerais pesados do Xingu a montante do Iriri sugere proveniência de rochas metamórficas de grau baixo (presença de andalusita), médio (presença de cianita e estaurolita) e alto (presença de sillimanita), além de prováveis rochas ígneas (alta porcentagem de turmalina e zircão).

A semelhança entre a assembleia de minerais pesados do setor 5 e do setor 6, correspondente ao rio Xingu a montante do Iriri, indica contribuição subordinada de sedimentos derivados do rio Iriri. Dentre as amostras do setor 5, as que apresentam maiores índices de granada (XNG 33, XNG 42, XNG 47 e XNG 48) indicam maior contribuição de areias do rio Iriri. Estas amostras têm maiores porcentagens de areia grossa e muito grossa, se comparadas com amostras vizinhas (Figura 23.). Isto indica dificuldade do rio Xingu para misturar suas areias durante o transporte.

A assembleia de minerais pesados do setor 3 é similar à do setor 5 . A grande variância da quantidade de granada neste setor, de 0\% (XNG 65-T) a 8.6\% (XNG 68), também reflete a dificuldade de mistura das areias.

O setor 2, pela grande variação na assembleia de minerais pesados, sugere sedimentos de proveniência distinta. Escorregamentos a partir de escarpas erosivas adjacentes ao canal e tributários menores (igarapés) que alimentam este setor podem contribuir com areias de fonte local. Destaca-se ainda canal ao norte deste setor interligado com o rio Amazonas e que forma delta na margem esquerda do rio Xingu. A grande porcentagem de turmalina e zircão nas areias deste setor, que somam cerca de 49,8\%, sugere proveniência com maior contribuição de rochas ígneas.

O sinal TL e A-LOE do quartzo é resposta dos seus defeitos cristalinos. Esta característica está associada à gênese do quartzo e principalmente à sua história sedimentar (Sawakuchi et al., 2011a). As areias do rio Iriri apresentam baixo sinal e variância reduzida dos sinais TL e A-LOE, se comparadas às 
areias do rio Xingu à montante do rio Iriri. Isto estaria relacionado ao menor percurso, área de drenagem mais reduzida e rochas fonte menos diversificada para os sedimentos deste setor do rio Iriri. Assim, areias com sinais luminescentes variáveis indicam histórias deposicionais diferentes, o que permite inferir sua proveniência em termos de distância da área fonte.

Pelas médias das medidas dos sinais TL e LOE, é possível calcular a porcentagem de sedimentos dos setores 7 e 6 nos demais setores do rio Xingu. Os gráficos da Figura 29 apresentam as porcentagens de contribuição do quartzo dos setores 6 e 7 para as amostras dos demais setores do rio Xingu.
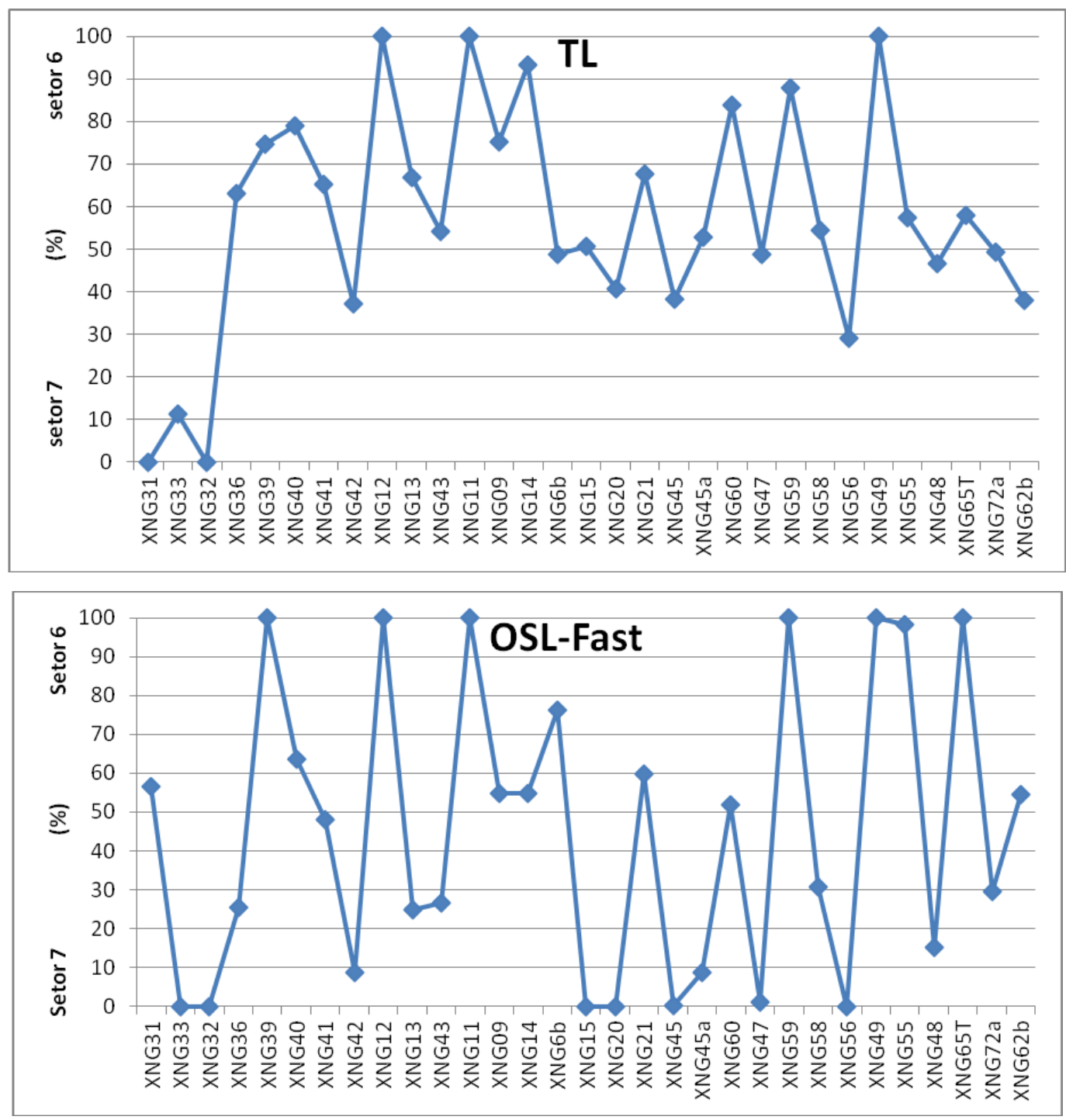

Figura 29. Porcentagem relativa da contribuição dos setores 7 (rio Iriri) e 6 (rio Xingu à montante do rio Iriri) para as amostras dos setores do rio Xingu à jusante do rio Iriri. 
As medidas da luminescência do feldspato (IR-LOE) também apresentaram tendência de variação oscilatória, similar à observada para a luminescência do quartzo (Figura 30).

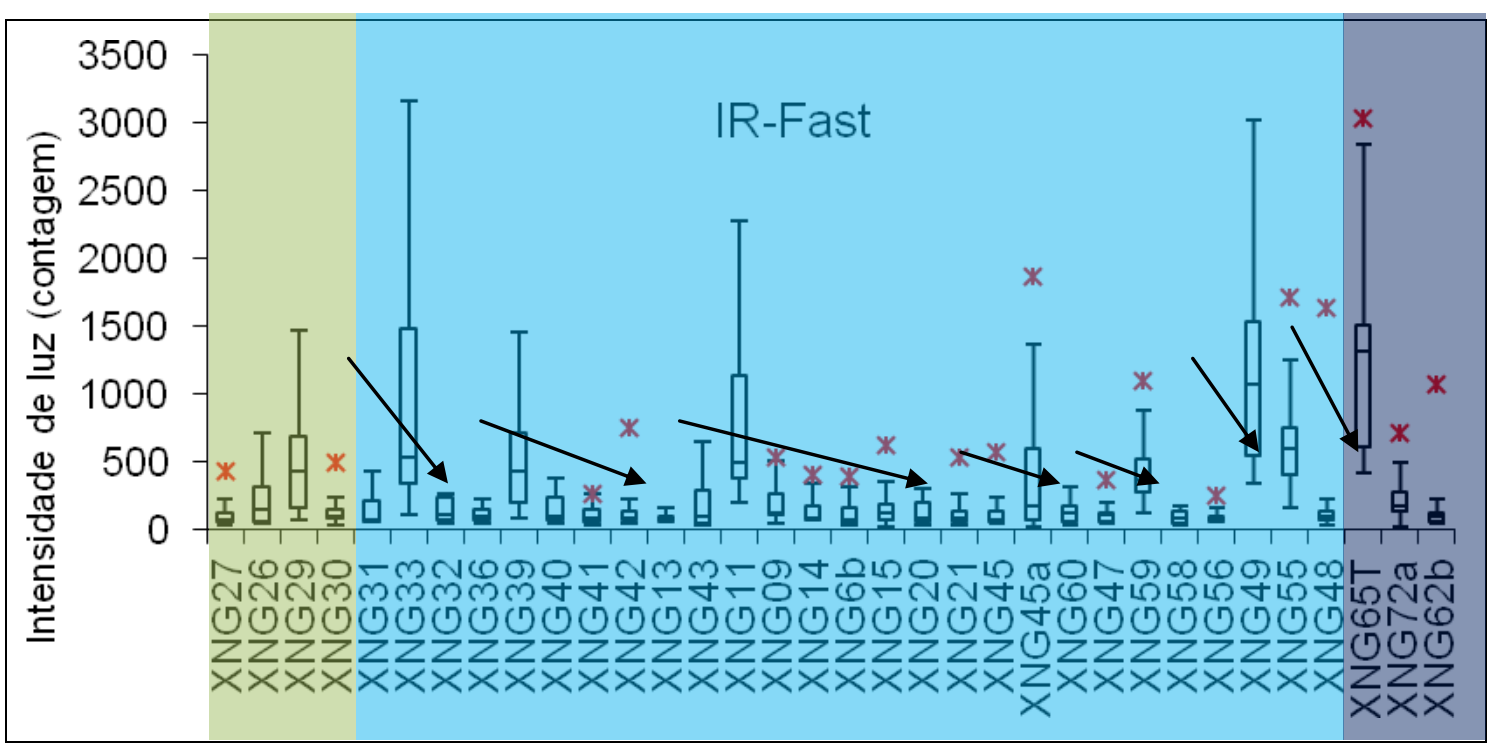

Figura 30. Gráficos boxplot do sinal IR-LOE. Setas indicam compartimentos do rio Xingu com redução do teor de feldspato em direção à jusante. Amostras do setor 6 em verde, setor 5 em azul e setor 3 em roxo.

Nota-se grande variação na porcentagem de sedimentos do rio Iriri (setor 7) no decorrer do percurso do rio Xingu (setores 5 e 3). A oscilação observada nas medidas TL, IR-LOE e A-LOE das amostras do rio Xingu a jusante do Iriri são reflexo da variação da contribuição das areias derivadas do rio Irir.

Esses padrões de variação da luminescência do quartzo e da granulação das areias indicam forte compartimentação do transporte e deposição de sedimentos ao longo da Volta Grande do rio Xingu (Figuras $31 \mathrm{e}$ 32). A sensibilidade LOE e TL baixa indica zonas com concentração de sedimentos mais proximais, com menor grau de retrabalhamento, enquanto que a sensibilidade alta indica zonas com alta concentração de sedimentos distais e mais retrabalhados. Assim, sedimentos mais ricos em areia fina devem ser provenientes de fontes mais distais enquanto que os sedimentos mais ricos em areia grossa devem vir de fontes mais proximais. Deste modo, as zonas com redução de sensibilidade devem estar associadas ao 
aprisionamento de sedimentos mais proximais derivados do rio Iriri. Isto pode explicar a relação entre granulometria e sensibilidade (Figura 33).

As zonas com concentração de sedimentos revelam dificuldade do rio Xingu em misturar os sedimentos de proveniência distal e proximal. Isto pode estar relacionado à sua dinâmica fluvial condicionada por canais múltiplos que dificultam a mistura de sedimentos. Trechos com acúmulo de sedimentos de granulação mais fina e sinal luminescente mais elevado (destaque amarelo nas figuras 31,32 e 34) estão em áreas de confinamento do fluxo por barreiras naturais. No rio Xingu, as barragens naturais são formadas por adensamento de barras e canais e afloramentos do substrato rochoso.

Embora as barragens naturais causem acúmulo de sedimentos, o sinal luminescente elevado do quartzo do setor 3 sugere que há transferência de sedimentos vindos do setor 6 . Assim, as barreiras do rio Xingu podem atuar como "peneiras" naturais, que retém sedimentos de granulação distinta em determinados trechos do rio. A oscilação da granulação e da luminescência do quartzo no curso do rio Xingu sugerem transporte diferenciado de areias grossas e finas por rotas distintas com estocagem temporária de sedimentos em determinados compartimentos do rio.

Assim, a grande densidade de barras ao final do setor 5 exerce papel de barragem natural, de modo que indicam estocagem temporária de sedimentos antes de serem transportados para setores seguintes.

O setor 3 também apresenta exemplo de barragem natural. Este setor é definido como canal único e encaixado que desemboca para canal largo e afogado (setor 2). Essa feição faz com que a vazão naquele trecho seja reduzida, diminuindo a velocidade da corrente e consequentemente a energia necessária para transporte das areias, o que gera depósito em barras longitudinais semelhantes à delta. 


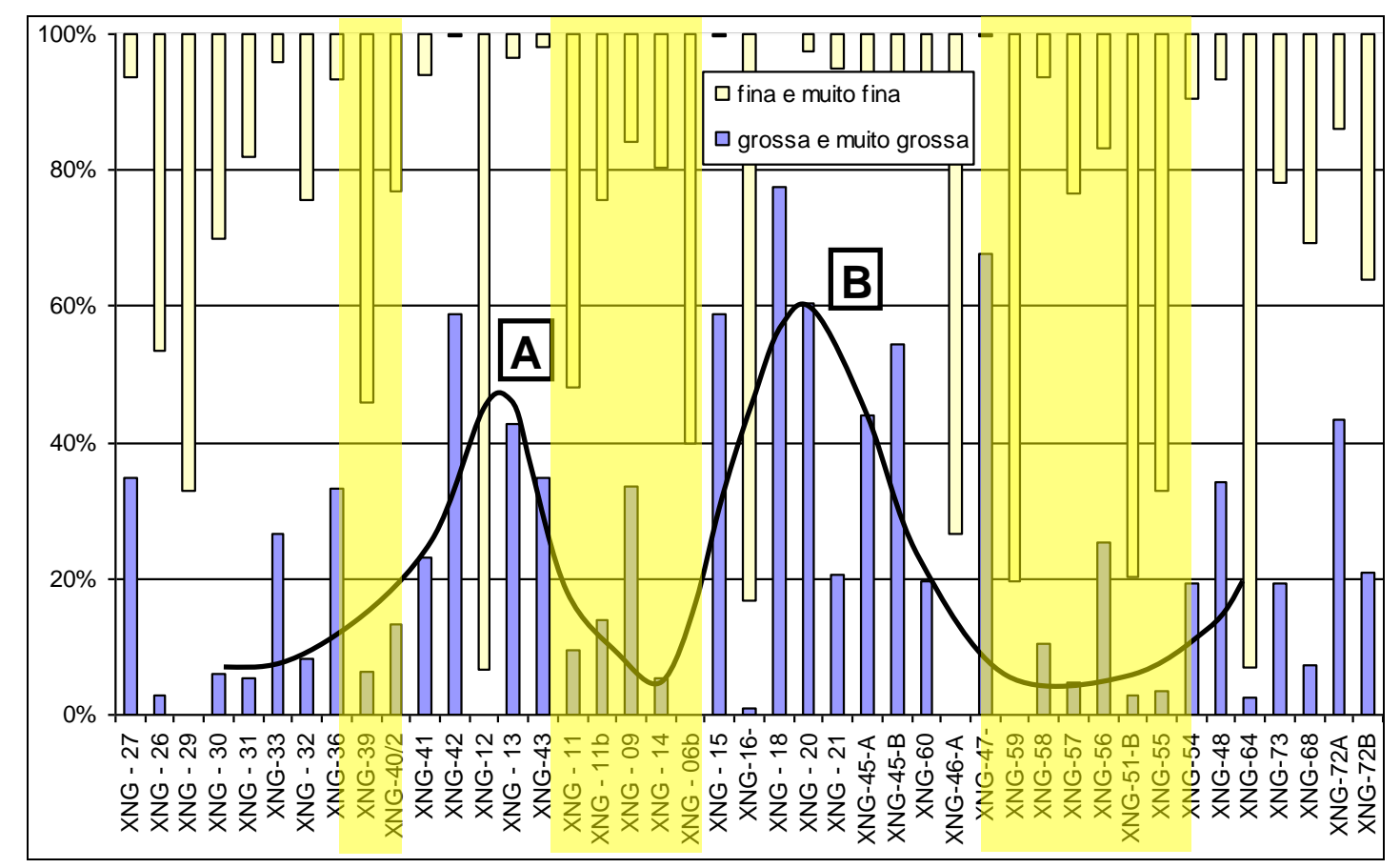

Figura 31. Porcentagens de areia muito fina a fina e grossa a muito grossa em ao longo da Volta Grande do rio Xingu. Nota-se oscilação na granulação média das amostras destacado pela linha preta. $O$ realce em amarelo marcam as regiões do setor 5 com estocagem de sedimentos mais finos e com maior luminescência do quartzo. As letras "A" e "B" apontam para as regiões com acúmulo de sedimentos mais grossos e menor sinal luminescente do quartzo.

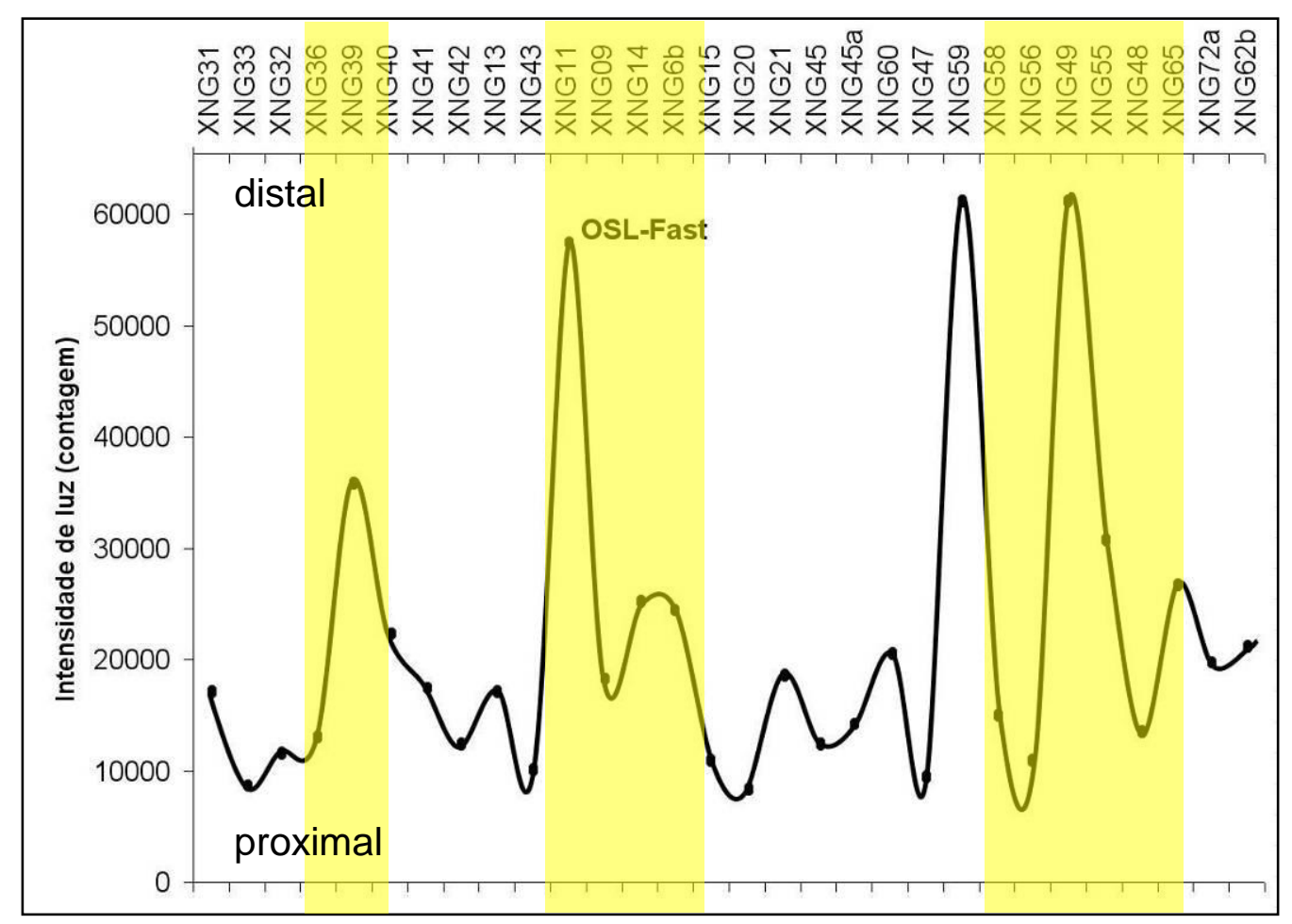


Figura 32. Gráfico das medianas das medidas A-LOE do quartzo (fração 0,125$0,250 \mathrm{~mm}$ ) das amostras da Volta Grande do rio Xingu. Sinais altos de luminescência coincidem com amostras com maior proporção de areias finas. $O$ destaque em amarelo marca as regiões do setor $5 \mathrm{com}$ estocagem de sedimentos mais finos e sinal luminescente do quartzo maior.

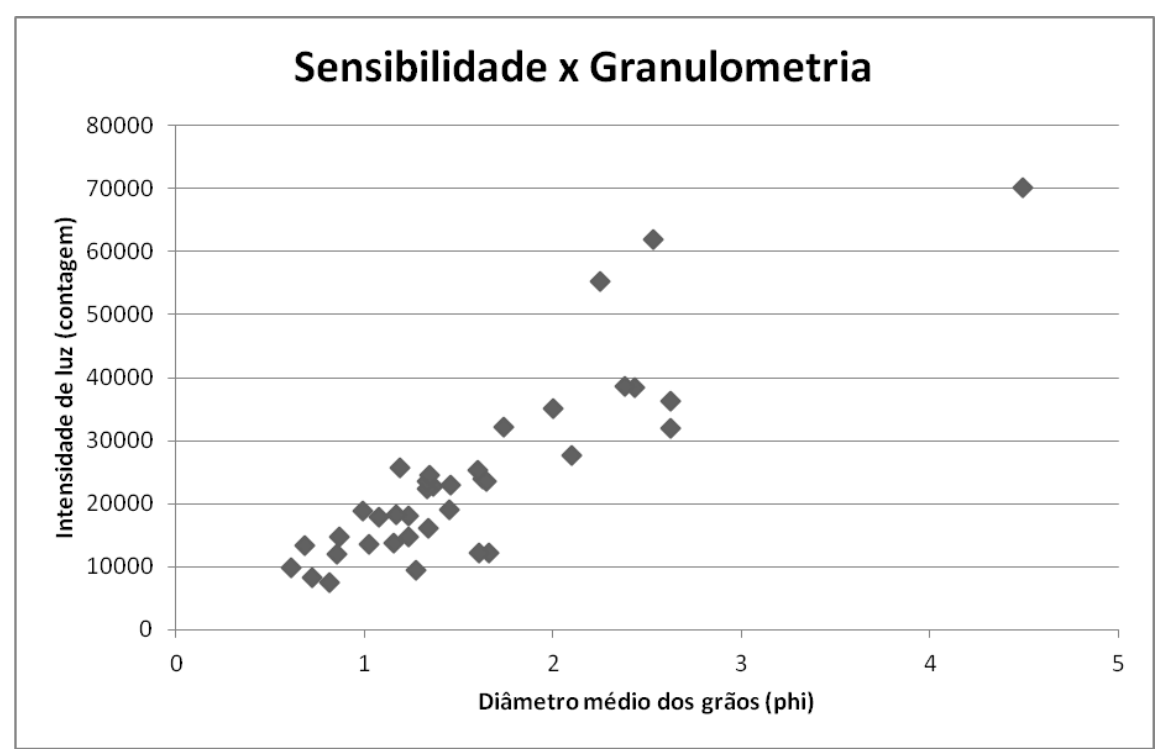

Figura 33. Correlação entre sensibilidade A-LOE (estímulo por luz azul) e diâmetro médio da fração areia. $\mathrm{O}$ quartzo de areias de granulação mais fina apresenta maior grau de retrabalhamento, indicativo de proveniência mais distal. Escala granulométrica: areia grossa (0-1 phi), areia média (1-2 phi), areia fina (2-3 phi), areia muito fina (3-4 phi). 


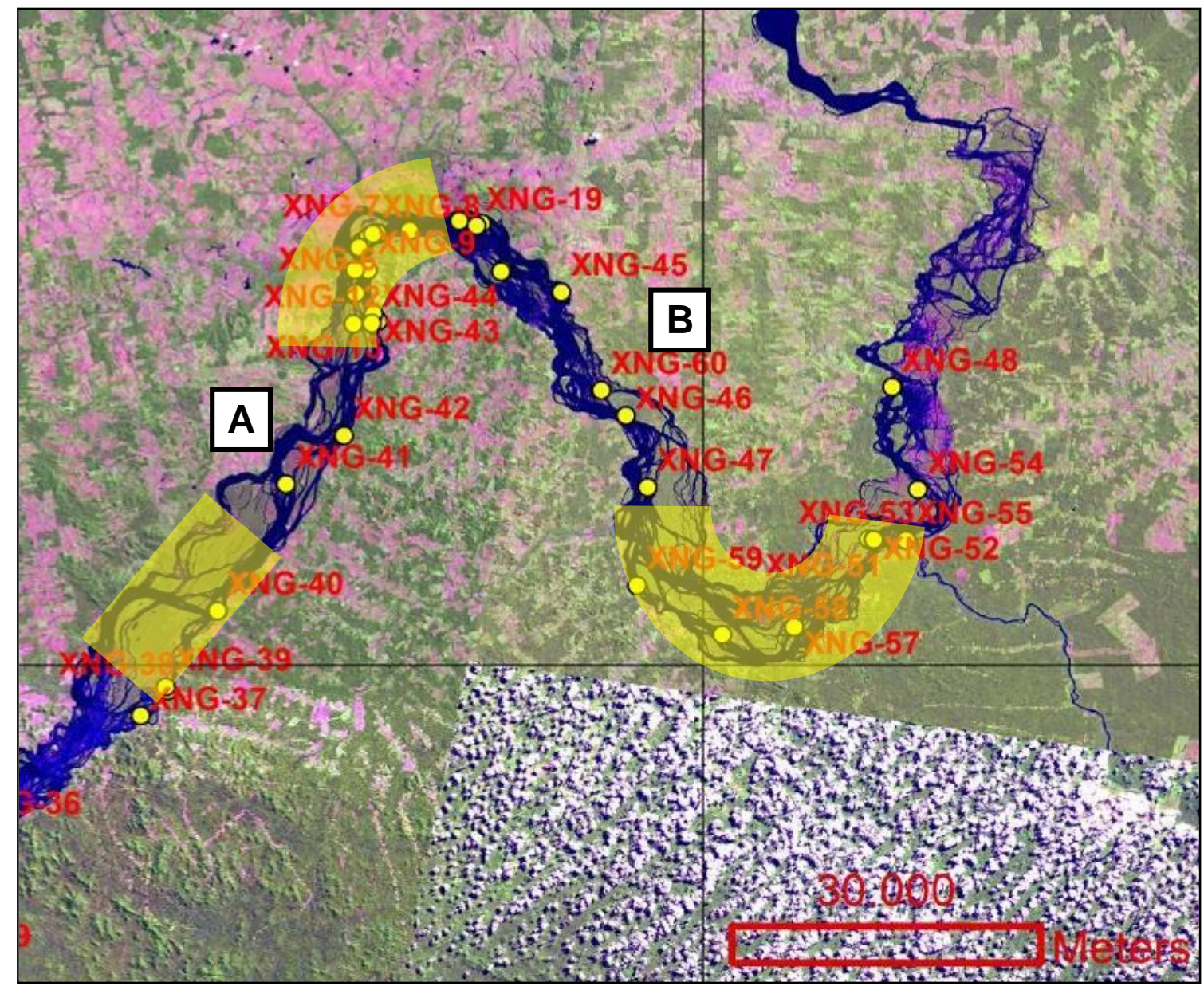

Figura 34. Mapa de detalhe da região da Volta Grande. Os destaques em amarelo revelam regiões com acúmulo de sedimentos no setor 5 que apresentam estocagem de sedimentos mais finos e sinal luminescente do quartzo maior. As letras "A" e "B" apontam para as regiões com acúmulo de sedimentos mais grossos e sinal luminescente do quartzo menor.

O fato do setor 2 praticamente não possuir barras arenosas emersas indica transporte de sedimentos arenosos dificultado em relação aos outros setores. As águas com correntes fracas e a morfologia de afogamento podem inibir o transporte das areias acumuladas no leito e margens do canal. Isto pode esclarecer sua assembleia de minerais pesados distinta. As correntes de maré e geradas por ondas também podem ocasionar aprisionamento das areias naquele setor, dificultar a chegada de sedimentos vindos de setores a montante e até contribuírem para o acúmulo de sedimentos no setor 3 .

A morfologia de canal afogado do setor 2 pode estar relacionada a barramento natural imposto pelos grandes depósitos em barra $(>20 \mathrm{~km}$ em extensão) na confluência do rio Xingu com o rio Amazonas. Estes depósitos 
barram o fluxo d'água, convertendo o curso do rio Xingu em um canal estreito com vazão confinada. O curso do rio Xingu neste ponto tem comunicação com o rio Amazonas, principal contribuinte dos grandes depósitos em barra do setor 1.

Como as barragens naturais permitem estocagem temporária de sedimentos nos diversos setores do rio Xingu, a grande sazonalidade do rio Xingu pode ter grande papel fundamental na transferência de sedimentos entre os diversos setores da Volta Grande. Períodos de cheia podem ter maior energia de transporte em trechos que na seca tem propensão ao acúmulo de sedimentos. Trechos com acúmulo de sedimentos podem exigir diferentes níveis de energia para o transporte, que podem ser alcançados com alterações climáticas globais e regionais de escala interanual, como o ENSO e variação do ITCZ, além de ciclos milenares de climas secos e úmidos propostos pelos trabalhos de Laskar et al. (2004) e Van Breukelen et al. (2008), por exemplo.

\subsection{Possíveis impactos na dinâmica sedimentar associados ao empreendimento hidroelétrico de Belo Monte}

O empreendimento hidroelétrico de Belo Monte visa sustentar dois reservatórios na região da Volta Grande do rio Xingu. Um deles usará o próprio canal do rio, desde proximidades com a foz do rio Iriri até região com maior adensamento de canais. Outro reservatório será formado por inundação em região entre os setores 5 e 3 (Figura 35). 


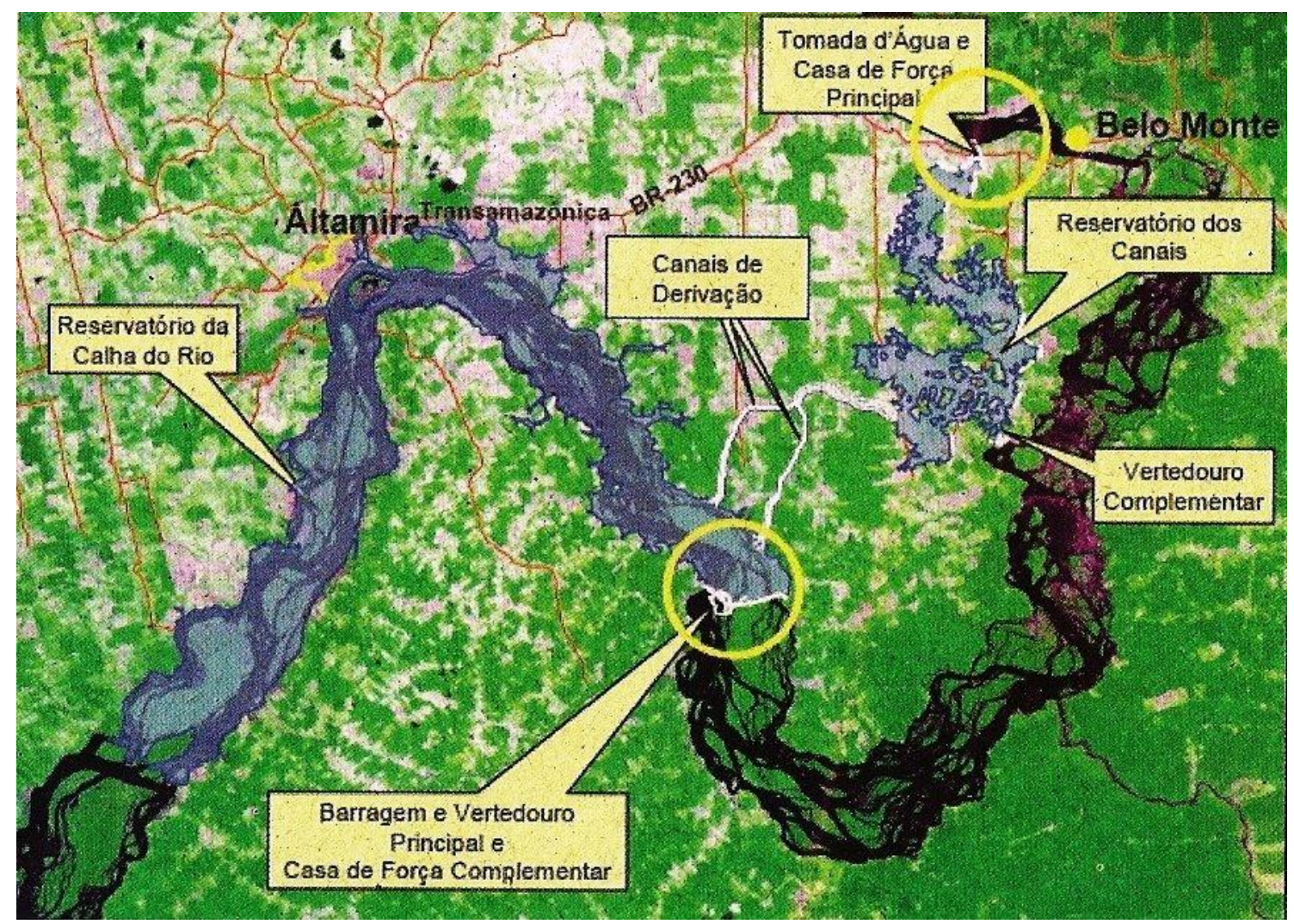

Figura 35. Mapa da região da Volta Grande do rio Xingu, com localização das barragens da hidroelétrica de Belo Monte.

A construção de hidroelétricas gera diversas consequências para o rio. A principal é o afogamento do canal a montante da barragem, que pode se estender por kilômetros de distância. O afogamento de um trecho do canal adultera os regimes de vazão e variação do nível d'água. Essas mudanças, além de prejudiciais do ponto de vista biológico e sócio-econômico, implicam em transformações abruptas na geomorfologia do rio e na dinâmica de transporte de sedimentos.

O curso do rio Xingu apresenta um equilíbrio atual de sedimentação e erosão que deve apresentar mudanças em escala centenária e milenar. Este equilíbrio é ditado por grandes variações sazonais e interanuais da vazão. $O$ afogamento do canal proposto no EIA-RIMA do empreendimento hidroelétrico de Belo Monte pode reduzir a vazão da Volta Grande (setor 4 e 5) e a consequente diminuição da transferência de sedimentos para o trecho afogado (setores 2 e 3), modificando este equilíbrio. Isso poderá provocar a retenção de sedimentos, o que causaria assoreamento do rio Xingu nos setores 5 e 6 e do rio Iriri. $O$ canal afogado pela barragem da calha do rio Xingu desenvolveria 
morfologia semelhante à do setor 2 , sendo os depósitos de areias similares às do setor 3 .

O reservatório da calha do rio Xingu poderá comprometer o regime sazonal de vazão, que pode ser o principal responsável pelo transporte de areias ao longo da Volta Grande do rio Xingu. O equilíbrio do rio Xingu também será alterado pela redução do aporte sedimentar em regiões imediatamente à jusante da barragem do reservatório da calha do rio. Estas regiões poderão apresentar maior denudação de barras estabilizadas, principalmente quando se controla a vazão pela abertura de comportas. Este tipo de atividade ocasiona 0 salto hidráulico, responsável por turbulência de alta escala e propagação de ondas superficiais à jusante e consequente aumento do potencial erosivo. A barragem posicionada no curso do rio está na região com maior densidade de barras estabilizadas da Volta Grande do rio Xingu. A estabilidade em escala decadal destas barras pode ser alterada, já que perderão aporte sedimentar regular e poderão sofrer eventos abruptos de erosão caso ocorra o salto hidráulico. Como o setor 2 apresenta fisiografia de canal afogado e dificuldade em receber areias transportadas a partir do setor 3 , de modo análogo pode ocorrer acúmulo de sedimentos vindos das barras à jusante da barragem na calha do rio Xingu, o que pode ocasionar assoreamento do setor 5 e erosão do complexo de barras do trecho de montante do setor 3 .

\section{Conclusões}

1- Zonas com mudança abrupta do curso do rio Xingu e à jusante de barreiras naturais configuram zonas afogadas, com redução da vazão do canal. Já zonas encachoeiradas ou com canais retilíneos estreitos aumentam a vazão.

2- No rio Xingu, barramentos naturais, tais como zonas com adensamento de canais e barras, aprofundamento abrupto do canal, afloramentos do substrato rochoso proporcionam alterações na dinâmica fluvial que podem favorecem a deposição ou transporte de areias em duas modas granulométricas (areias grossas e finas). Isto favorece a formação de regiões propícias a estocagem ou transferência de sedimentos, onde 0 
regime da vazão e o espaço de acomodação definem a deposição de sedimentos.

3- Areias finas têm história sedimentar longa e, portanto, passaram por mais ciclos de deposição/exumação do que as areias grossas. Isto gera a "oscilação" observada nos dados de sensibilidade da luminescência das areias distribuídas ao longo da Volta Grande do rio Xingu.

4- Areias de granulação grossa a muito grossa se concentram em regiões específicas de estocagem de sedimentos. Estas areias seriam derivadas principalmente do rio Iriri.

5- As areias fornecidas pelo rio Iriri são de proveniência proximal, indicada pelo elevado teor de granada e feldspato e quartzo com baixa sensibilidade da luminescência.

6- As barragens naturais do rio Xingu atuam como peneiras, segregando 0 transporte de areias em duas modas distintas, representadas por areias grossa e muito grossa derivadas do rio Iriri e areias fina e muito fina derivadas do rio Xingu a montante da confluência com o rio Iriri. Isto dificulta a mistura das areias dos rios Iriri e Xingu ao longo da Volta Grande.

\section{Referências bibliográficas}

Aitken, M.J., 1998. An introduction to optical dating. Oxford University Press, p. 267.

Amaral, G., 1980. Conhecimento Atual da Geologia da Região Amazônica. In: Simpósio Sobre as Características Geológico-Geotectônicas da Região Amazônica. ABGE, pp. 01-43.

Baker, P.A., Seltzer, G.O., Fritz, S.C., Dunbar, R.B., Grove, M.J., Tapia, P.M., Cross, S.L., Rowe, H.D., Broda, J.P., 2001a. The history of South American tropical precipitation for the past 25,000 years. Science, v. 291, p. 640-643.

Baker, P.A., Rigsby, C.A., Seltzer, G.O., Fritz, S.C., Lowensteink, T.K., Bacher, N.P., Veliz, C., 2001b. Tropical climate changes at millennial and orbital timescales on the Bolivian Altiplano. Nature, v. 409, p. 698-671.

Barbouti, A.I., Rastin, B.C., 1983. A study of the absolute intensity of muons at sea level and under various thickness absorber. Journal of Physics G. Nuclear Physics, v. 9, p. 1577-1595.

Basu, A., 1985b. Reading provenance from detrital quartz. In: Provenance of Arenites. Ed.: Zuffa, G.G. Reidel Publ., Dordrecht, p. 231- 247. 
Behling, H., Bush, M., Hooghiemstra, H., 2010. Biotic development of Quaternary Amazonia: a palynological perspective. In: Amazonia Landscape and Species Evolution. Eds.: Hoorn C., Wesselingh F.P., Wiley, Oxford, p. 335-346.

Bernet, M. and Bassett, K.N., 2005. Single quartz grain SEM-CL/optical microscopy provenance analysis. Journal of Sedimentary Research, v . 75 (3), p. 576-590.

Blatt, H., Christie, J.M., 1963. Undulatory extinction in quartz of igneous and metamorphic rocks and its significance in provenance studies of sedimentary rocks. Journal of Sedimentary Petrology, v. 33, p. 559-579.

Bøtter-Jensen, L., Agersnap Larsen, N., Mejdahl, V., Poolton, N.R.J., Morris, M.F., McKeever, S.W.S., 1995. Luminescence sensitivity changes in quartz as a result of annealing. Radiation Measurements, $v$. 24 , n. 4 , p. 535-541.

Bush, M.B., Miller, M.C., Oliveira P.E., Colinvaux, P.A., 2000. Two histories of environmental change and human disturbance in eastern lowland Amazonia. The Holocene, v. 10, 5, p. 543-553.

Bush, M.B., Silman, M.R., Urrego, D.H., 2005. 48,000 years of climate and forest change in a biodiversity hot spot. Science, v. 303, p. 827-829.

Caputo, M.V., 1984. Stratigraphy, Tectonics, Paleoclimatology and Paleogeographyof Northen Basins of Brasil. Thesis (PHD) - University Califórnia, Santa Bárbara. 586p.

Cohen, M.C.L., Behling, H., Lara, R.J., 2005. Amazonian mangrove dynamics during the last millennium: The relative sea-level and the Little Ice Age. Review of Palaeobotany and Palynology, v. 136, p. 93-108.

Costa, M.L., 1991. Aspectos geológicos dos lateritos da Amazônia. Revista Brasileira de Geociências, v. 21, n.12, p. 146-160.

Costa, J.B.S., Bemerguy, R.L., Hasui, Y., Borges, M.S., Ferreira Júnior, C.R.P., Bezerra, P.E.L., Costa, M.L., Fernandes, J.M.G., 1996. Neotectônica da região amazônica: aspectos tectônicos, geomorfológicos e deposicionais. Geonomos, v.2, p. 23-44.

Cruz Junior, F.W., Wang, X., Auler, A. Vuille, M., Burns, S.J., Karmann, I., Edwards, L.R., Cheng, H., 2009. Orbital and millennial-scale precipitation changes in Brazil from speleothem records. In: Past climate variability from the last glacial maximum to the Holocene in South America and surrounding regions. Eds.: Vimeux, F., Sylvestre, F., Khodri, M., Springer-Verlag, v. 1, p. 29-60.

Choi, J.H., Duller, G.A.T., Wintle, A.G., Cheong, C.-S., 2006. Luminescence characteristics of quartz from the Southern Kenyan Rift Valley: Dose estimation using LM-OSL SAR. Radiation Measurements 41, 847-854.

Costa, M.G.F., 1984. Fácies deposicionais e ambientes de sedimentação da Formação Monte Alegre (Neocarbonífero) na área de Autás Mirim e adjacências, Bacia do Médio Amazonas. Disertação de Mestrado, Universidade Federal de Pernambuco, Recife. 90p. 
Cunha, F.M.B., 1991. Morfologia e Neotectonismo do Rio Amazônas. In: Anais do Simpósio de Geologia da Amazônia, Belém. SBG, pp. 193-210.

David, M., Sunta, C.M., 1981. Thermoluminescence of quartz - Part VIII: Estimation of Firing Temperature in Ancient Pottery Samples. Indian Journal of Pure \& Applied Physics 19, 1054-1056.

Dennen, W.H., Blackburn, W.H., Quesada, A., 1970. Aluminum in quartz as a geothermometer. Contributions to Mineralogy and Petrology, v. 27, p. 332-342.

Folk, R.L., 1974. Petrology of sedimentary rocks. Austin, TX, Hemphill, p. 182.

Haberle, S.G., Maslin, M.A., 1999. Late Quaternary vegetation and climate change in the Amazon Basin based on a 50,000 year pollen record from the Amazon Fan, ODP site 932. Quaternary Research, v. 51, p. 27-38.

Huntley, D.J., Godfrey-Smith, D.I., Thewalt, M.L.W., 1985. Optical dating of sediments. Nature, v. 313, p. 105-107.

Huntley, D.J., 1995. On the zeroing of the thermoluminescence of sediments. Physics and Chemistry of Minerals, v. 12, p. 122-7.

Irion, G., Müller, J., Mello, J.N., Junk, W., 1994. Quaternary Geology of Central Amazonian lowland area. Revista do Istituto Geológico, São Paulo, v. 15(1/2), p. 27-33.

Jacob, J., Huang, Y., Disnar, J.R., Sifeddine, A., Boussafir, M., Albuquerque, A.L.S., Turcq, B., 2007. Paleohydrological changes during the last deglaciation in Northern Brazil. Quaternary Science Reviews, v. 26, p. 10041015.

Koul, D.K., 2006. Role of alkali ions in limiting the capacity of the $110^{\circ} \mathrm{C}$ peak of quartz to remember the firing temperature. Applied radiation and Isotopes 64, 110-115.

Koul, D.K., Chougaonkar, M.P., 2007. The pre-dose phenomenon in the OSL signal of quartz. Radiation Measurements 42, 1265-1272.

Kuhn, R., Trautmann, T., Singhvi, A.K., Krbetschek, M.R., Wagner, G.A., Stolz, W., 2000. A study of thermoluminescence emission spectra and optical stimulation spectra of quartz from different provenances. Radiation Measurements 32, 653-657.

Latrubesse, E.M., Stevaux J.C., Sinha R., 2005. Tropical Rivers. Geomorphology 70, 187-206.

Li, S.H., 2002. Luminescence sensitivity changes of quartz by bleaching, annealing and UV exposure. Radiation Effects and Defects in Solids 157, 357-364.

Ludwing, G. D., 1964. Divisão estratigráfico-faciológica do Paleozóico da Bacia Amazônica. Ciência Técnica Petróleo. Rio de Janeiro. Petrobrás. Seção: Exploração do Petróleo, n 1. 72p.

Marchant, R., Hooghiemstra, H., 2004. Rapid environmental change in African and South American tropics around 4000 years before present: a review. Earth-Science Reviews, v. 66, p. 217-260. 
Marengo, J.A., Nobre, C.A., Tomasella, J., Oyama, J.M., Oliveira, G.S., Oliveira, R., Camargo, H., Alves, L.M., Brown, I.F., 2005. The drought of Amazonia in 2005. Americam Meteorological Society, vol. 21, p. 495-516.

Maslin, M.A., Burns, S.J., 2000. Reconstruction of the Amazon Basin effective moisture availability over the past 14,000 years. Science, v. 290 , p. $2285-$ 2287.

Maylea, F.E., Beerling, D.J., 2004. Late Quaternary changes in Amazonian ecosystems and their implications for global carbon cycling. Palaeogeography, Palaeoclimatology, Palaeoecology, v. 214, p. 11-25.

McKeever, S.W.S., 1985. Thermoluminescence of solids. Cambridge University Press, Cambridge.

McKeever, S.W.S., Bøtter-Jensen, L., Agersnap Larsen, N., Mejdah, V., Poolton, N.R.J., 1996. Optically stimulated luminescence sensitivity changes in quartz due to repeated use in single aliquot readout: experiments and computer simulations. Radiation Protection Dosimetry 65(1-4), 49-54.

Molinier, M., Guyot, J.L., Oliveira, E., Guimarães, V., Chaves, A., 1995. Hidrologia da Bacia do Rio Amazonas. Ciência e Tecnologia, CPRM, v. 1, p. 31-36.

Moska, P., Murray, A.S., 2006. Stability of the quartz fast-component in insensitive samples. Radiation Measurements 41, 878-885.

Murray, A., Wintle, A.G., 2000. Luminescence dating of quartz using an improved single-aliquot regenerative-dose protocol. Radiation Measurements 32, 57-73.

Pettena, J.L., Barros, A.L.M.M., Matos, W.D., Ribeiro, A.C.O., Carvalho, R.M., 1980. Estudos de Inventário Hidrelétrico na Amazônia: A Bacia do Rio Xingu. In: Simpósio Sobre as Características Geológico-Geotectônicas da Região Amazônica. ABGE, pp. 115-136.

Pietsch, T.J., Olley, J.M., Nanson, G.C., 2008. Fluvial transport as a natural luminescence sensitiser of quartz. Quaternary Geochronology 3, 365-376.

Poolton, N.R.J., Smith, G.M., Riedi, P.C., Bulur, E., Bøtter-Jensen, L., Murray, A.S., Adrian, M., 2000. Luminescence sensitivity changes in natural quartz induced by high temperature annealing: a high frequency EPR and OSL study. Journal of Physics D: Applied Physics 33, 1007-1017.

Poveda, G., Waylen, P.R., Pulwarty, R.S., 2006. Annual and inter-annual variability of the present climate in northern South America and southern Mesoamerica. Palaeogeography, Palaeoclimatology, Palaeoecology, v.234, p. 3-27.

Prescott, J.R., Stephan, L.G., 1982. The contribution of cosmic radiation to the environmental dose for TL dating. Latitude, altitude and depth dependancies. PACT, v. 6, p. 17-25.

Preusser, F., Chitambo, M.L., Götte, T., Martini, M., Ramseyer, K., Sendezera, E.J., Susino, G.J., Wintle, A.G., 2009. Quartz as a natural luminescence dosimeter. Earth-Science Reviews 97, 184-214. 
Rink, W.J., Rendell, H., Marseglia, E.A., Luff, B.J., Townsend, P.D., 1993. Thermoluminescence spectra of igneous quartz and hydrothermal vein quartz. Physics and Chemistry of Minerals 20, 353-361.

Rink, W.J., Toyoda, S., Rees-Jones, J., Schwarcz, H.P., 1999. Thermal activation of OSL as a geothermometer for quartz grain heating during fault movements. Radiation Measurements 30, 97-105.

Rodriguez, S.K., 1993. Neotectônica e Sedimentação Quaternária na Região da "Volta Grande" do Rio Xingu, Altamira, PA. Dissertação de Mestrado, Instituto de Geociências da Universidade de São Paulo, São Paulo. 106p.

Rocha Neto, M.B., 2004. Programa Geologia do Brasil - PGB. Carta Geológica do Brasil ao Milionésimo. Folha Belém SA-22.

Rossetti, D.F., Valeriano, M.M., THALES, M., 2007. An abandoned estuary within Marajó Island: implications for Late Quaternary paleogeography of Northern Brazil. Estuaries and Coasts, v. 30, n. 5, p. 813-826.

Salgado-Labouriau, M.L., Barberi, M., Ferraz-Vicentini, K.R., Parizzi, M.G., 1998. A dry climatic event during the late Quaternary of tropical Brazil. Review of Palaeobotany and Palynology, v. 99, p. 115-129.

Sawakuchi, A.O., Blair, M., DeWitt, R., Faleiros, F.M., Hyppolito, T.N., Guedes, C.C.F., 2011a. Thermal history versus sedimentary history: OSL sensitivity of quartz grains extracted from rocks and sediments. Quaternary Geochronology, v. 6, p. 261-272.

Sawakuchi, A.O., DeWitt, R., Faleiros, F.M., 2011b. Correlation between thermoluminescence sensitivity and crystallization temperatures of quartz: potential application in geothermometry. Radiation Measurements 46, 51-58.

Sawakuchi, G.O., 2003. Elucidando a gênese da cor do quartzo irradiado. Dissertação de mestrado, Instituto de Física da Universidade de São Paulo. São Paulo, p. 234.

Sifeddine, A., Wirrmannc, D., Albuquerqueb, A.L.S., Turcqa, B., Cordeiro, R.C., Gurgela, M.H.C., Abrão, J.J., 2004. Bulk composition of sedimentary organic matter used in palaeoenvironmental reconstructions: examples from the tropical belt of South America and Africa. Palaeogeography, Palaeoclimatology, Palaeoecology, v. 214, p. 41- 53.

Siqueira, A.H.B., Souza, L.O., Vaz, J.C.M., Molion, L.C.B.,Bernardo, S.O., Salvador, M.A., Oliveira, J.P.P., 2006. Impactos do ENOS no Norte e Nordeste Brasileiros e sua relação com a Oscilação Decadal do Pacifico. In: XIV Congresso Brasileiro de Meteorologia, SBMET, Florianópolis (SC). XIV Congresso Brasileiro de Meteorologia, 2006.

Souza Filho, E.E., Santos, M.V., Borduque, M., Ribeiro, A.L.O., Payola, B.L. 1988. A Formação Trombetas nas proximidades de Belo Monte - PA. Sítio da UHE de Kararaô. $35^{\circ}$ Congresso Brasileiro de Geologia, Belém (PA), v. 2, p. 123-724.

Tassinari, C.C.G., Macambira M.J.B., 1999. Geochronological Provinces of the Amazonian Craton. Episodes 22(3),174-182.

Tassinari, C.C.G., Macambira M.J.B., 2004. A Evolução Tectônica do Cráton Amazônico. In: V. Mantesso-Neto, A. Bartorelli, C.D.R. Carneiro, B.B. Brito 
Neves (eds) Geologia do Continente Sul-Americano: Evolução da Obra de Fernando Flávio Marques de Almeida, 28, Becca, pp. 471-485.

Thomaz Filho, A., Cordani, U.G., Marino, O., 1974. Idades K-Ar de rochas basálticas da Bacia Amazônica e sua significação tectônica regional. In: Congresso Brasileiro de Geologia, 28. Porto Alegre. Anais. São Paulo: Sociedade Brasileira de Geologia. 6, 273-278.

Van Breukelen, M.R., Vonhof, H.B., Hellstrom, J.C., Wester, W.C.G., Kroon, D., 2008. Fossil dripwater in stalagmites reveals Holocene temperature and rainfall variation in Amazonia. Earth and Planetary Science Letters, v. 275, p. 54-60.

Van der Hammen, T., Hooghiemstra, H., 2000. Neogene and Quaternary history of vegetation, climate, and plant diversity in Amazônia. Quaternary Science Reviews, v. 19, p. 725-742.

Vital, H., Stattegger, K., 2000. Lowermost Amazon River: evidence of late Quaternary sea-level fluctuations in a complex hydrodynamic system. Quaternary International, v. 72, p. 53-60.

Vitorino, M.I., Silva, M.M., Silva, R.P., 2006. Eventos de precipitação durante a estação seca no Estado do Amazonas. In: XIV Congresso Brasileiro de Meteorologia, SBMET, Florianópolis (SC). XIV Congresso Brasileiro de Meteorologia, 2006.

Vonhof, H.B., Kaadorp, R.J.G., 2010. Climate variation in Amazonia during the Neogene and the Quaternary. In: Amazonia Landscape and Species Evolution. Eds.: Hoorn C., Wesselingh F.P., Wiley, Oxford, p. 201-210.

Wang, X., Auler, A.S., Edwards, R.L., Cheng, H., Ito, E., Wang, Y., Kong, X., Solheid, M., 2007. Millennial-scale precipitation changes in southern Brazil over the past 90,000 years. Geophysical Research Letters, v.34, L23701, doi: 10.1029/2007GL031149.

Wintle, A.G., Murray, A.S., 2006. A review of quartz optically stimulated luminescence characteristics and their relevance in single-aliquot regeneration dating protocols. Radiation Measurements, v. 41, p. 369391.

Wintle, A.G., 2008. Fifty years of luminescence dating. Archaeometry, v. 50, n. 2, p. 276-312.

Wintle, A.G., 2008. Luminescence dating: where it has been and where it has going. Boreas, v. 37, p. 471-482.

Sites:

http://hidroweb.ana.gov.br/ 
Dados referentes à Agência Nacional de Águas (ANA) de estações pluviométricas e fluviométricas na bacia de drenagem do Rio Xingu. Acessado em Agosto de 2011.

http://www.sismo.iag.usp.br/sismologia/

Mapa de sismicidade no Brasil. Acessado em Dezembro de 2011. 